Informes de la Construcción Vol. 26, nº 250

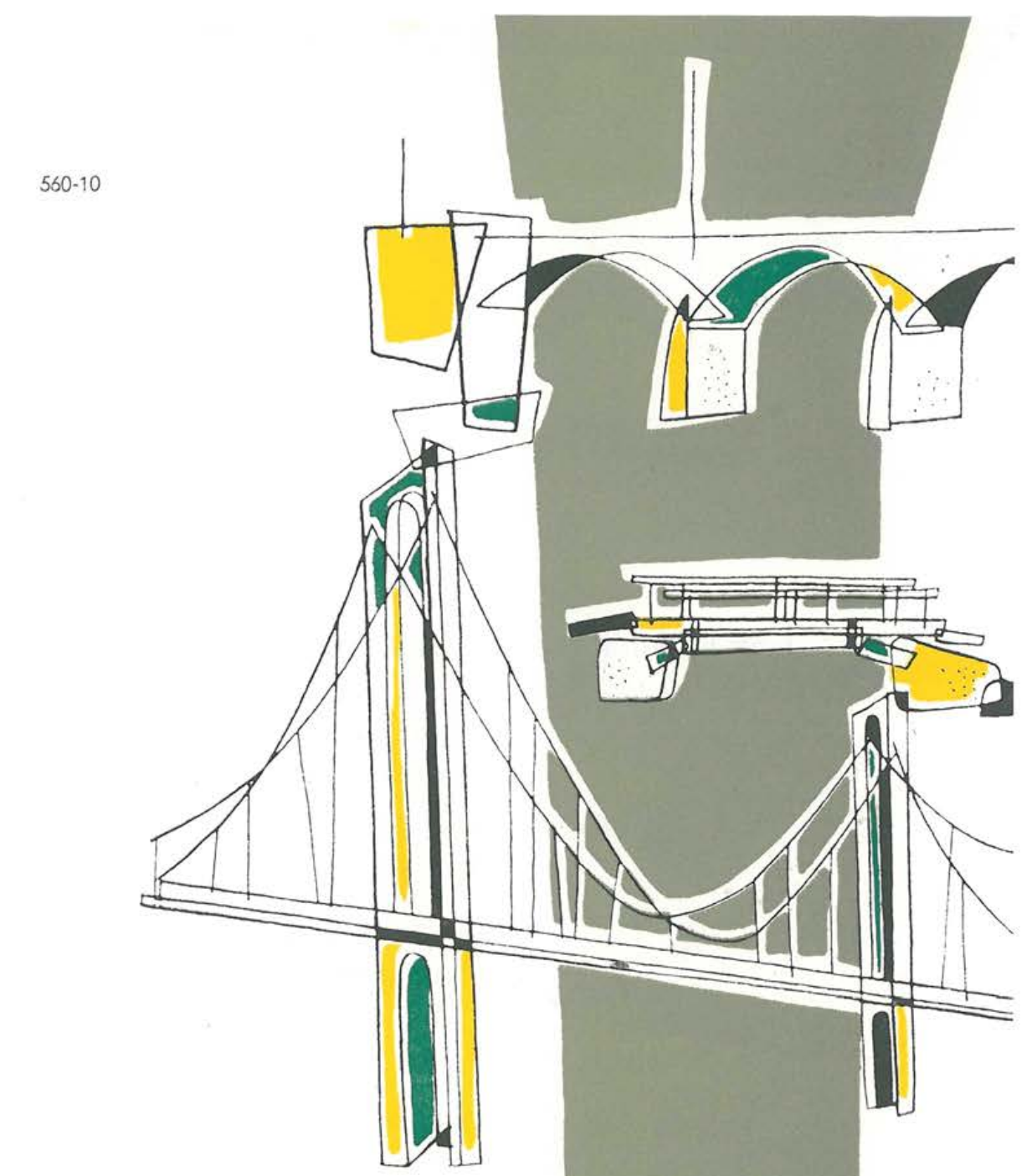

\title{
historia del puente en España
}

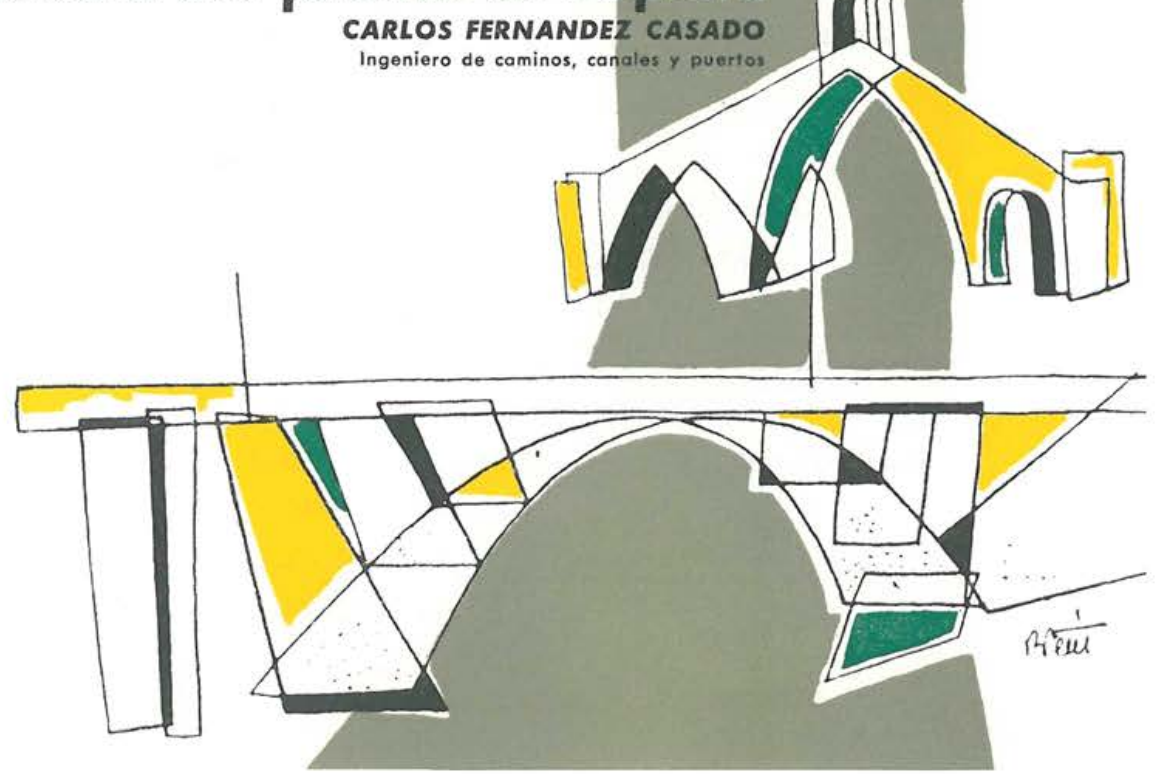


Con la publicación de este artículo sobre los puentes de la Bética continuamos la serie

"HISTORIA DEL PUENTE EN ESPAÑA", que se completará en sucesivos números de Informes.

Como ya se indicó, todas estas publicaciones aisladas constituirán, en su día, los Capítulos de un libro sumamente interesante y sugestivo.

El puente es una de las claves de la historia de la construcción española. En la Oficina técnica del Ing. D. Carlos Fernández Casado se estudian bajo un prisma de unidad de síntesis entre lo técnico y lo artístico, con lo que su valoración es completa. 


\section{historia del puente en España}

\section{introducción}

La provincia Bética, que consideramos en la máxima amplitud que tuvo, es la más determinada geográficamente de las cinco que llegaron a integrar la organización administrativa del Imperio romano. El contorno sur coincide con el de la Península, a oriente sigue el curso del río Anas, persistiendo en ello por el norte hasta llegar al codo del Cíjara; desde aquí va a buscar la divisoria de aguas del Betis en toda su cuenca alta, continuando después en la dirección em. prendida hasta la costa que alcanza a mitad de distancia entre los cabos de Palos y de Gata.

El eje de la provincia es el Betis, "gran río, gran padre de Andalucía» que le dio nombre, cambiados ambos, a ella por los vándalos $\mathrm{y}$ a él por los musulmanes, que también denominan casi todos los ríos que soportan nuestros puentes. Perdido para río y provincia el nombre quedó únicamente en las sierras Bética, Penibética y Sub-bética.

El otro río caudal, éste con nombre no trocado sino ampliado a Guad-Anas, que forma el límite superior, como ya hemos indicado, le roba aguas por medio de afluentes poco importantes, salvo el Zújar y el Guadamez. También pierde aguas, que van a dar a la mar en la costa atlántica, por Tinto y Odiel en la zona media entre los dos grandes y después hasta el Estrecho encauzadas por ríos menores, Guadalete y Barbate, ríos nefastos en la historia de España por disputarse uno de los grandes descalabros nacionales. Pasada la columna Calpe tenemos ríos más menores: Guadarranque, Guadiaro, Guadalmina, Guadalhorce, Guadalmedina, Guadalentín, Vélez, Verde, Guadalfeo, Adra, Andarax y Almanzora.

En estos ríos hemos de encontrar nuestros puentes.

Pero también otro modo de buscarlos es seguir la red de vías romanas en la zona, que la encontramos determinada a su vez por condiciones geográficas, la base de las cuales es la red fluvial, ya que ésta ha condicionado de origen la organización de la red de caminos. $Y$ así efectivamente tenemos tres calzadas fundamentales: la que sigue el curso del Guadiana, la duplicada en parte del curso del Guadalquivir y la de la costa, que son, respectivamente, las $25+10 ; 34+7$; $5+6$ del Itinerario de Antonino. Entre ellas, transversales, aprovechando las facilidades de paso en la orografía que separa los ríos; cordilleras: Sierra Morena, Bética y la Penibética y macizos costeros de Lújar, Cázulas, Mijas, Retín, Grazalema. Estas vías unen las poblaciones importantes: Emérita-Hispalis, Emérita-Astigi y Emérita-Corduba y del otro Hispalis-Ostio Fluminis Anae en la desembocadura del Guadiaro, dando continuidad a la de la costa e Hispalis-Málaca, Corduba-Málaca y Cástulo-Hactara.

Las intersecciones de ambas redes nos señalan los puentes posibles y el método perfecto para encontrarlos sería seguir exhaustivamente una de ellas, mejor la natural de los ríos, ya que pueden existir puentes sin camino o ser a veces tan insignificante éste que no esté en las redes principales, aunque a la larga el puente, si es importante, le dará también importancia al camino. No hemos podido realizar este recorrido exhaustivo ni aún en los mapas aéreos, medio ya al alcance de cualquiera, pero exigiendo un esfuerzo en paciencia, tiempo y dinero poco abordable. En principio nos decidimos por las carreteras -ingeniero somos de Caminos- y nos hemos limitado al Itinerario de Antonino, completando nuestra información particular con la de los organismos de nuestra profesión: Jefaturas de Carreteras y Divisiones Hidráulicas, que tienen a su cargo caminos y ríos, respectivamente, manifestándoles desde aquí nuestro agradecimiento a su ayuda. 
Realmente, el método perfecto actual para estos problemas de arqueología ingenieril es el del recorrido desde helicóptero con la orientación previa de los planos obtenidos por fotografía aérea.

Resumiremos nuestro recorrido en el cual no hemos seguido esta perfecta fórmula, pero tenemos la esperanza de poderla poner en práctica para el estudio de vías romanas, de las cuales hemos empezado varias, pero no hemos terminado ninguna.

En la vía de la costa hemos tenido poco éxito en descubrir ruinas de puentes, pues la amplitud de los ríos y la naturaleza del terreno de cimentación cuando se trata de planas abiertas o, por el contrario, el carácter de accidentes secundarios cuando se trata de caminos desarrollados en las zonas más o menos escarpadas próximas al mar, han tenido más agentes destructivos cuando las obras tenían importancia, o es difícil descubrirlas cuando son insignificantes. En varias localizaciones hemos llegado a la conclusión de que no había obras permanentes, vadeándose el cauce salvo en las épocas de avenidas, o que se trataba de obras semi-permanentes, ya que aparecen ruinas de pilas sin arranques de arcos o de dimensiones que no hubieran aguantado los empujes correspondientes, y entonces debieron ser tableros adintelados que en época romana no pueden ser más que de madera, los cuales se reponían cuando se deterioraban por meteorización o por el uso, o se los llevaban las riadas. Así ocurre, por ejemplo, en el río Salado, de las proximidades de Tarifa. También existía la posibilidad de pasar en barca cuando la anchura era grande o vadearlos por la barra que forman las dunas avanzando hacia el interior. Así no hemos encontrado vestigios ni en el Barbate (Bessipone), ni en el río de la Miel (Portus Albus), ni en el Palmones, ni en el Guadarranque (Carteia), ni en el Guadiaro (Barbariana), ni en el Fuengirola (Suel), ni en el Guadalhorce, ni en el Guadalmedina (Málaca), ni en el Vélez, ni en los ríos Verde y Seco (Sexi), ni en el río Guadalfeo (Murgi), ni en la rambla de Buñol, ni en el río de Adra.

El puente de Zuazo (Ad Pontem), en la entrada al istmo de Cádiz, ha sufrido múltiples reconstrucciones; el actual es un puente de hormigón pretensado y el anterior se construyó en el siglo XV por el señor de Zuazo, y no quedan sillares romanos.

Siguiendo el río Betis o lo que es más fácil la vía Cástulo-Hispalis encontramos con que viene por la margen derecha del río, pues Cástulo está perfectamente fijada. Pasa a la contraria en las cercanías de la actual Espeluy, ya que la próxima mansión de la vía está en la margen opuesta. Además, tenemos un miliario in situ en las cercanías de Villanueva de la Reina; otro paso parece haber habido en Lituergo, ya que desde ahí en adelante aparecen vestigios en las dos orillas con una duplicación de la vía que pasa de un lado por Marmolejo (Uciense) y por Aldea del Río y del otro por Epora (Montoro). No encontramos vestigios de estos pasos, pero en cambio tenemos un hermoso puente auténticamente romano en Andújar (Iliturgi) y un pequeño puente sobre el Salado de Arjona, en las proximidades de Urgaone (Arjona). La llegada a Corduba se verifica por la orilla derecha, debiendo haberse reunido ambas vías por cruce probablemente donde hoy se asienta el puente de Alcolea, pues aunque el existente es de Carlos III, debe estar en el mismo emplazamiento que el romano.

De Corduba a Hispalis no aparecen en el Betis vestigios de puente, y la vía romana iba por la orilla izquierda, habiendo cambiado de orilla gracias al puente que perdura en la primera de dichas ciudades. El río era demasiado importante para un puente en camino transversal, y es sabido que Hispalis no tuvo cruce permanente hasta el puente de barcas construido por los árabes. En cambio, en ese mismo trozo de vía tenemos un puente importante sobre el Genil en Ecija y un puente sencillo en Carmona sobre un cauce insignificante. De Sevilla a Cádiz no hay cauces importantes hasta el río Guadalete cerca de Puerto de Santa María o el Caño de San Pedro. Siempre se ha hablado de puentes romanos en ambos cruces, pero los vestigios son difíciles de encontrar después de las obras sucesivas en las carreteras antiguas con puente metálico, actua con puente pretensado y a la del ferrocarril adyacente con tramo también metálico. Aparece un puente interesante junto a la carretera actual cerca de la estación de La Alcantarilla (nombre debido al puente) sobre un arroyo secundario, y es auténticamente romano.

En la vía de Hispalis a Ostio Flumina (Ayamonte) cruzamos primero Tinto y Odiel, el primero por un hermoso y auténtico puente en Niebla, y el segundo mediante vado estudiado cerca de Ad Rubras (Gibraleón). El cruce del Guadiana se haría mediante barca, pues su cauce estaba más allá de las posibilidades romanas.

De Emérita a Hispalis sólo hemos encontrado vestigios de pilas y arranques de arcos en el paso del arroyo de la Ribera de Huelva. 


\section{puentes de época imperial en la Bética}

Por contraste con los puentes de la Juritania donde encontrábamos el granito como material común a sus fábricas, ahora tenemos, por razones geográficas obvias, una gran diversidad de materiales, siendo el menos frecuente precisamente aquél. Las sillerías son de caliza o arenisca, y cuando las canteras quedan lejanas, para obras de pequeña importancia, se utiliza el ladrillo que, por compensación, es de buena calidad y se maneja con verdadero arte.

Esta diversidad de materiales da lugar a importantes variaciones no sólo en el aparejo de las fábricas, sino en la traza de las obras. La labor es más fina y el corte más perfecto debido a su mayor facilidad a las herramientas del cantero, lo que hace que el aparejo sea más cuidado y permita llegar a una íntima trabazón entre las diversas partes de la obra. Como ejemplo de esta realización más terminada podemos poner los dos puentes de Alcantarilla y del arroyo Rabanales, y especialmente este último que en un arroyo de pequeña importancia alínea sus cinco arcos con rasante horizontal que nacen apenas desde cimientos con sus boquillas muy bien aparejadas, relacionándose todas entre sí por una faja de sillares en pequeño resalto que forma como una cornisa, tangente al trasdós de aquéllas, cosida en toda la longitud y trabada con otros sillares en superposición que forman como pilastras, encuadrando de este modo las boquillas de los arcos. Se obtiene así una perfecta trabazón arquitectónica entre las diversas partes.

Un detalle estilístico que encontramos en varios puentes de una cierta región es el engatillado de los sillares para evitar el deslizamiento relativo en dirección radial. Ya lo advertíamos en el puente sobre el Salado, en Porcuna; después aparecen en el del arroyo de los Pedroches, cerca de Córdoba, y en una alcantarilla intermedia en el arroyo de la Buena Agua, cerca de Alcolea, hoy en servicio en la carretera del embalse del Guadalmellato.

Otro detalle estilístico que no hemos encontrado hasta ahora y que es muy poco frecuente en nuestro país es de la archivolta, que separa mediante cornisa tosca la boquilla del arco de la superficie de tímpanos aunque se conserva el mismo plano en ambos paramentos. Este detalle es muy romano y aparece en los puentes de época imperial, tanto en Roma como en la Península, pero su origen es anterior, ya que aparece en los arcos de las puertas de entrada a las ciudades etruscas.

En cuanto a tipos, encuentra casi exclusivamente el puente bajo de varios arcos, con rasante horizontal o a dos aguas en poca pendiente. En general, los frentes se articulan marcando arranques de arcos y coronación de pilas y coronándose mediante cornisa sencilla. No existen arcos de aligeramiento, las relaciones de vano a macizo varían entre 1,00 y 1,90. Las fábricas, tanto de sillería como de ladrillo tienen aparejos sencillos pero cuidados. En los arcos de ladrillo se resalta su importancia, disponiendo la boquilla en varios planos. 


\section{fotoplano de Córdoba}

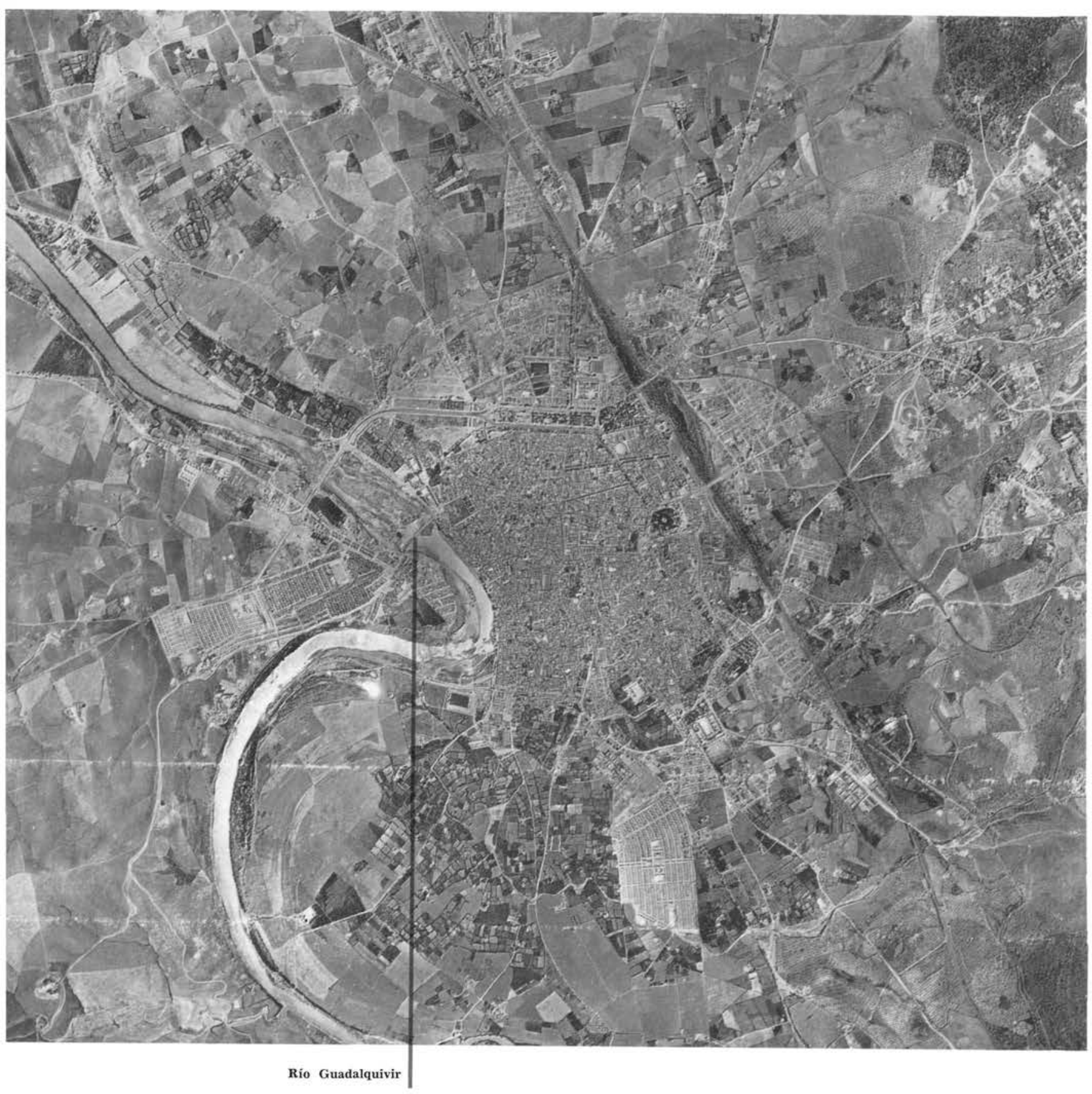

Puente romano 


\section{puente de Córdoba}

Es el más importante de todos los de la provincia Bética. Salva el Guadalquivir en una zona amplia centrado en una alineación recta, pero donde la violencia del río en avenidas resulta imponente, no desbordando las márgenes porque está encauzado mediante muros antiguos; además en avenidas extraordinarias se salía antes de tomar esta alineación, inundando una superficie extensa en la margen opuesta a la ciudad, conocida desde antiguo como Campo de la Verdad, y donde se edificó recientemente con cierta inconsciencia, que parece se ha subsanado mediante recrecimiento y refuerzo del muro correspondiente a dicha margen.

La ubicación del puente parece bien elegida porque, como ya hemos dicho, queda centrado en una alineación recta que aparece después de un violento codo, que actualmente se piensa cortar, ya que la incurvación correspondiente no sólo facilitaba el salirse de madre, sino que también, por mecanismo natural de meandro, tiende a ir angostando el cauce que, además de acercarse a la zona del puente, podría romper por el indicado campo inundable abriendo nuevo cauce que dejaría inservible el puente. Este desenlace no es inminente, pero va aumentando la probabilidad de que se produzca y ya se ha tomado en consideración. Dificultades materiales de expropiación, de ningún modo invencibles, han retrasado dicha corta, que está dentro del plan de protección de la ciudad contra las avenidas del Guadalquivir, pues ésta no se encuentra con una seguridad normal, ni mediante los muros de defensa directa, ni por la retención del agua en los embalses que están llegando al máximo de sus posibilidades.

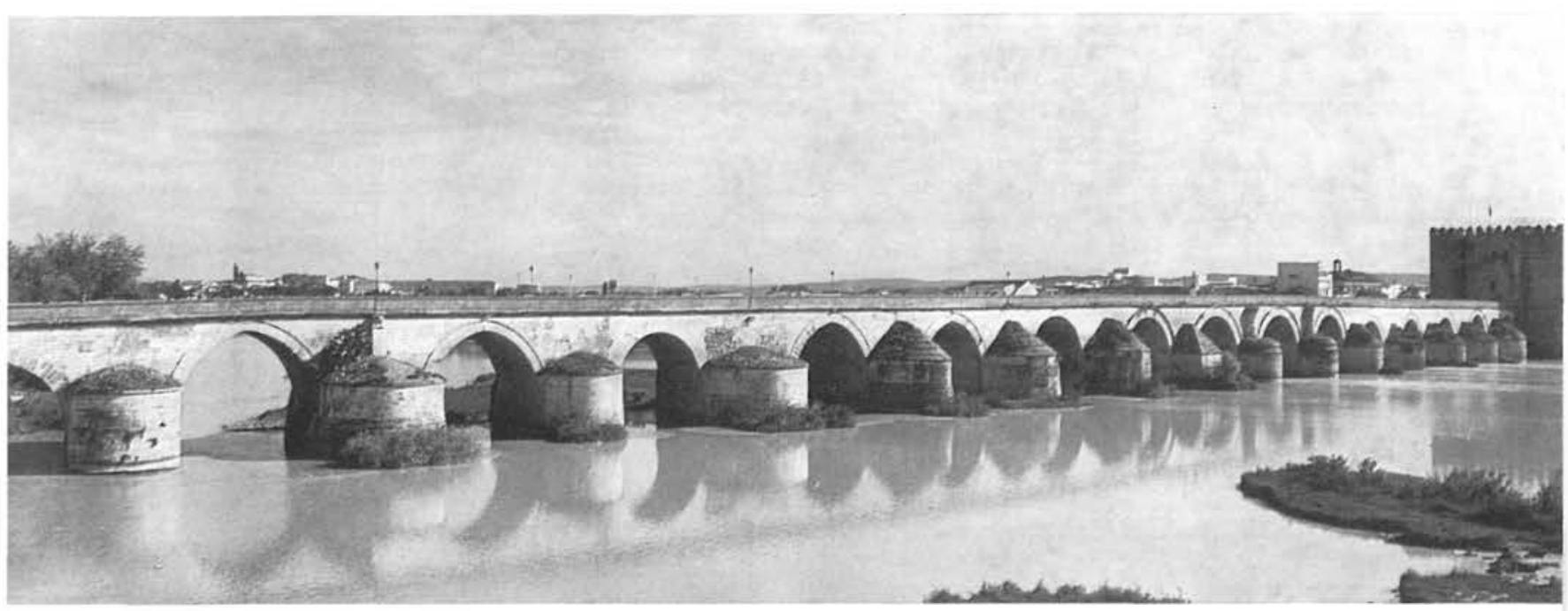

Vista general desde aguas abajo $\mathrm{y}$ margen derecha.

El paso del río por esta zona en estiaje pudo haber sido vadeable, aunque actualmente no lo sea por la reducción de desagüe lineal que han producido las infraestructuras del propio puente y las de los molinos que están a poca distancia aguas abajo, más el estrechamiento general debido al encauzamiento. Por este motivo lo más verosímil es que fuera un paso obligado de camino en esta zona poblada desde muy antiguo con una campiña baja muy fácil de regar y en una zona donde, además de la comunicación principal, antes vía Augustea y ahora carretera general de Andalucía, que venía por la orilla derecha y allí pasaba a la izquierda, tenemos las secundarias de enlace con el NO. hacia Mérida (Emérita Augusta) y con el SE. hacia Málaga (Málaca) e Iliberri y en época musulmana hacia Algeciras y Granada. 


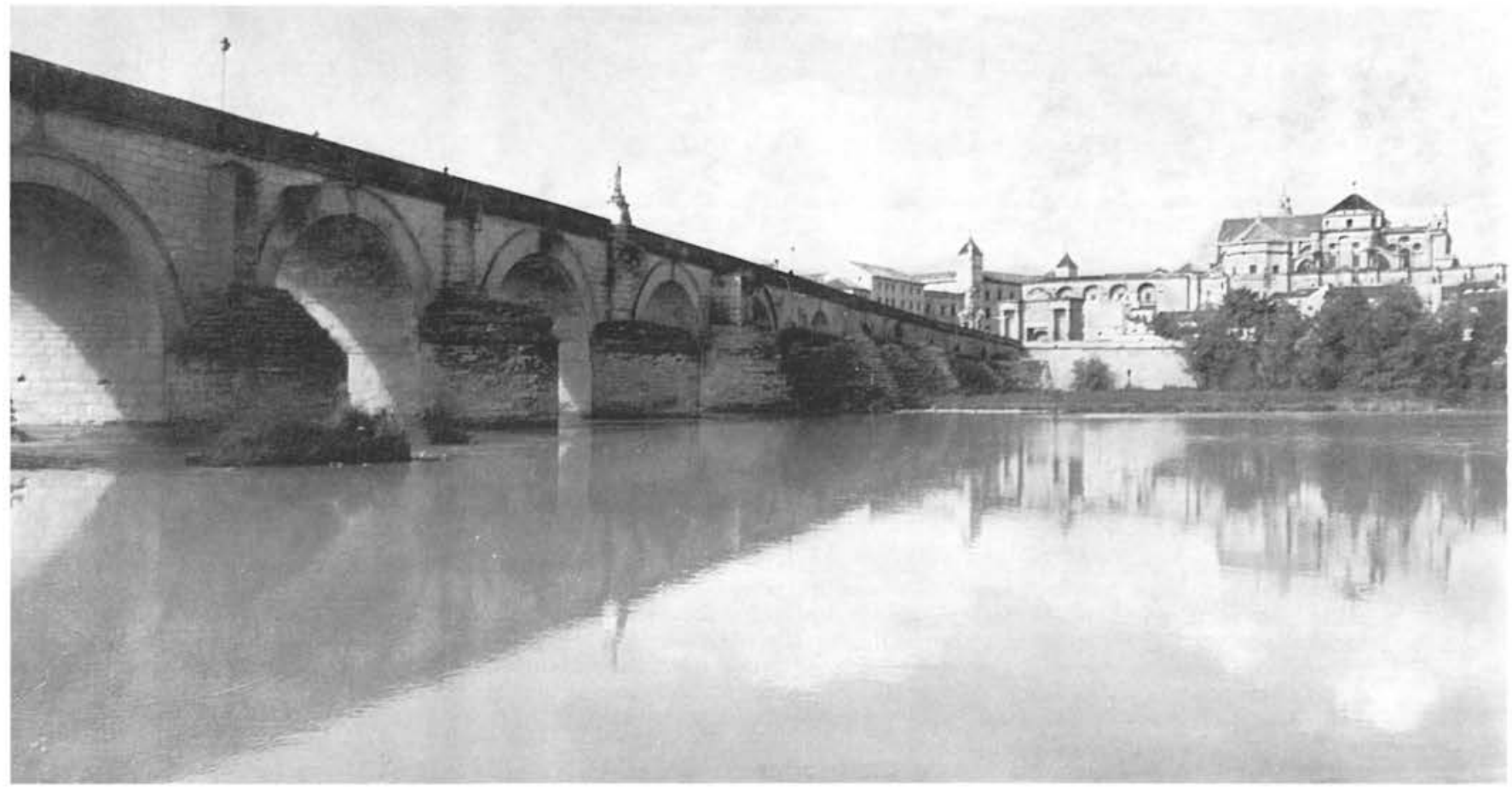

Vista general desde aguas arriba.

Una vez ya establecida la ciudad, el puente se ha hecho necesario para su normal desarrollo y hacer frente a las necesidades viales que el tráfico creciente planteaba. Así todos los gobernantes que han ejercido su potestad en ella se han preocupado de mantenerlo en forma, es decir, en servicio, realizando reparaciones unas veces para cumplir provisionalmente las deficiencias que se producian súbitamente y otras con un plan más ambicioso de restaurarle, no sólo sus condiciones de servicio sino su empaque monumental, como ornato y blasón de la ciudad, incorporando su aspiración de supervivencia a la pretensión de permanencia implícita en toda obra de piedra, asentada sobre los reales de un río, dada la continua destrucción que éste ejerce sobre la obra, ya que ésta es siempre un obstáculo más o menos resistente a su acción transformadora de la naturaleza de su lecho. El puente de piedra con sus pilas metidas dentro del cauce que ordenan las aguas normales.

Arcos centrales (8 a 11).

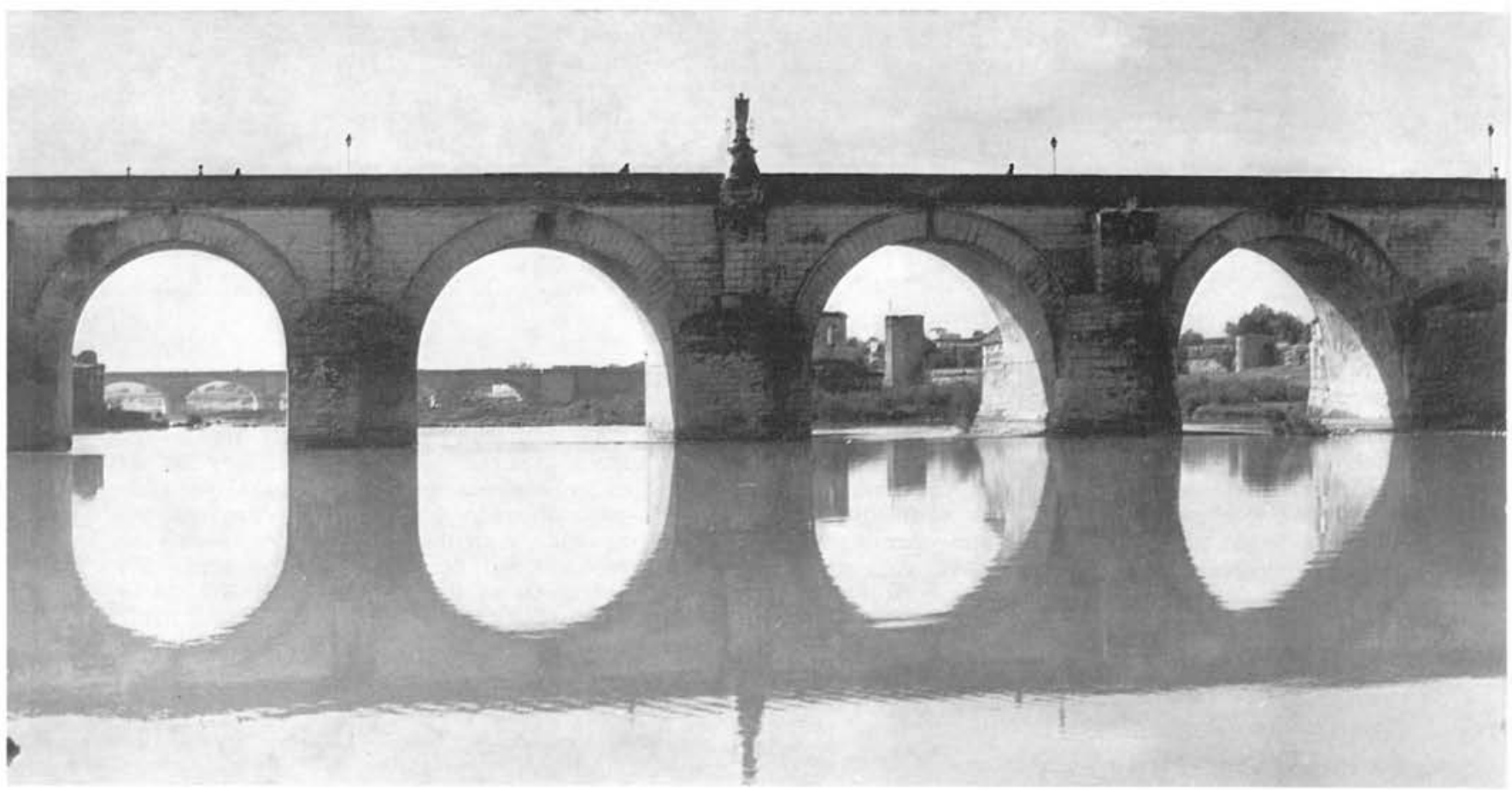




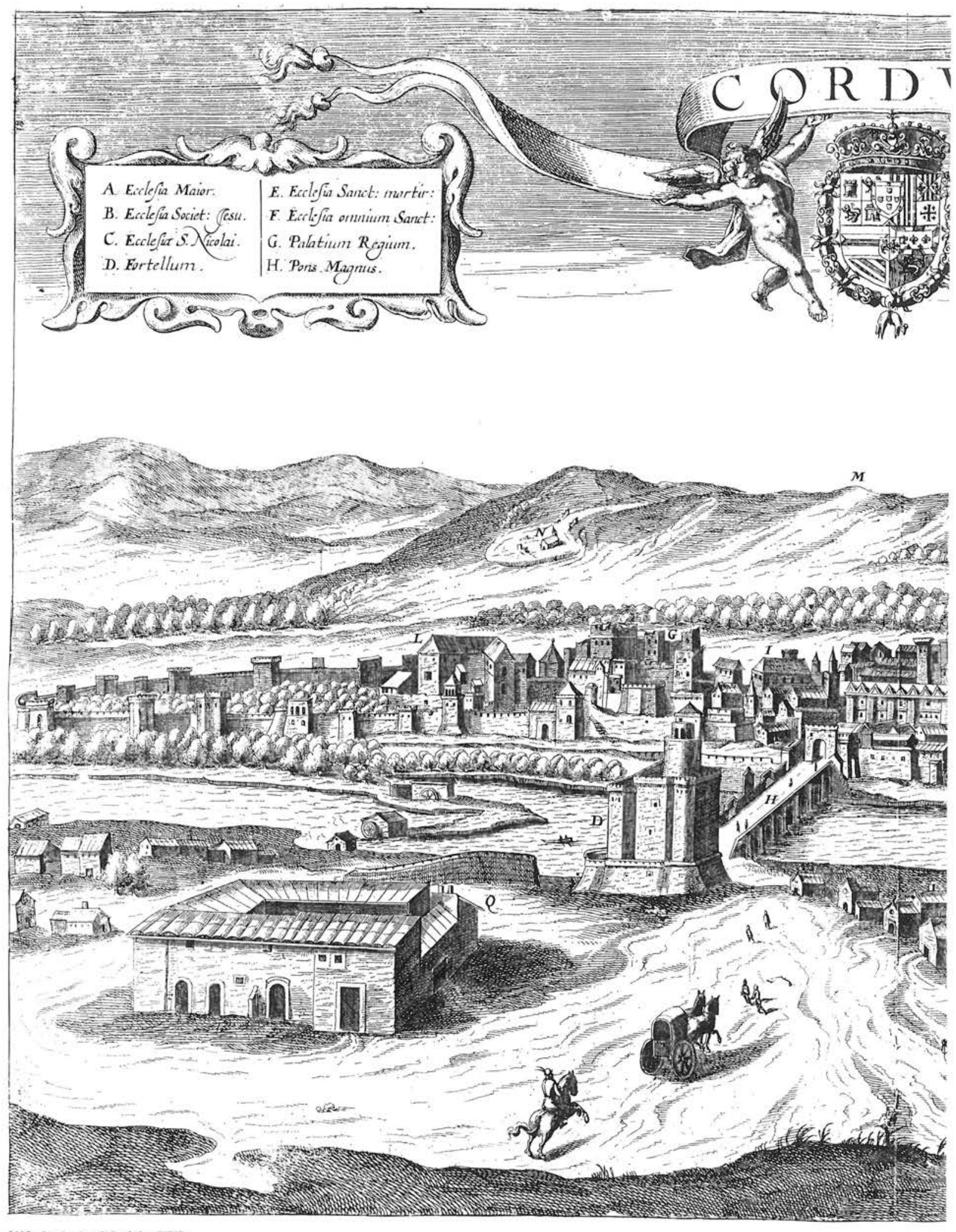

[32] Grabado del siglo XVI. 

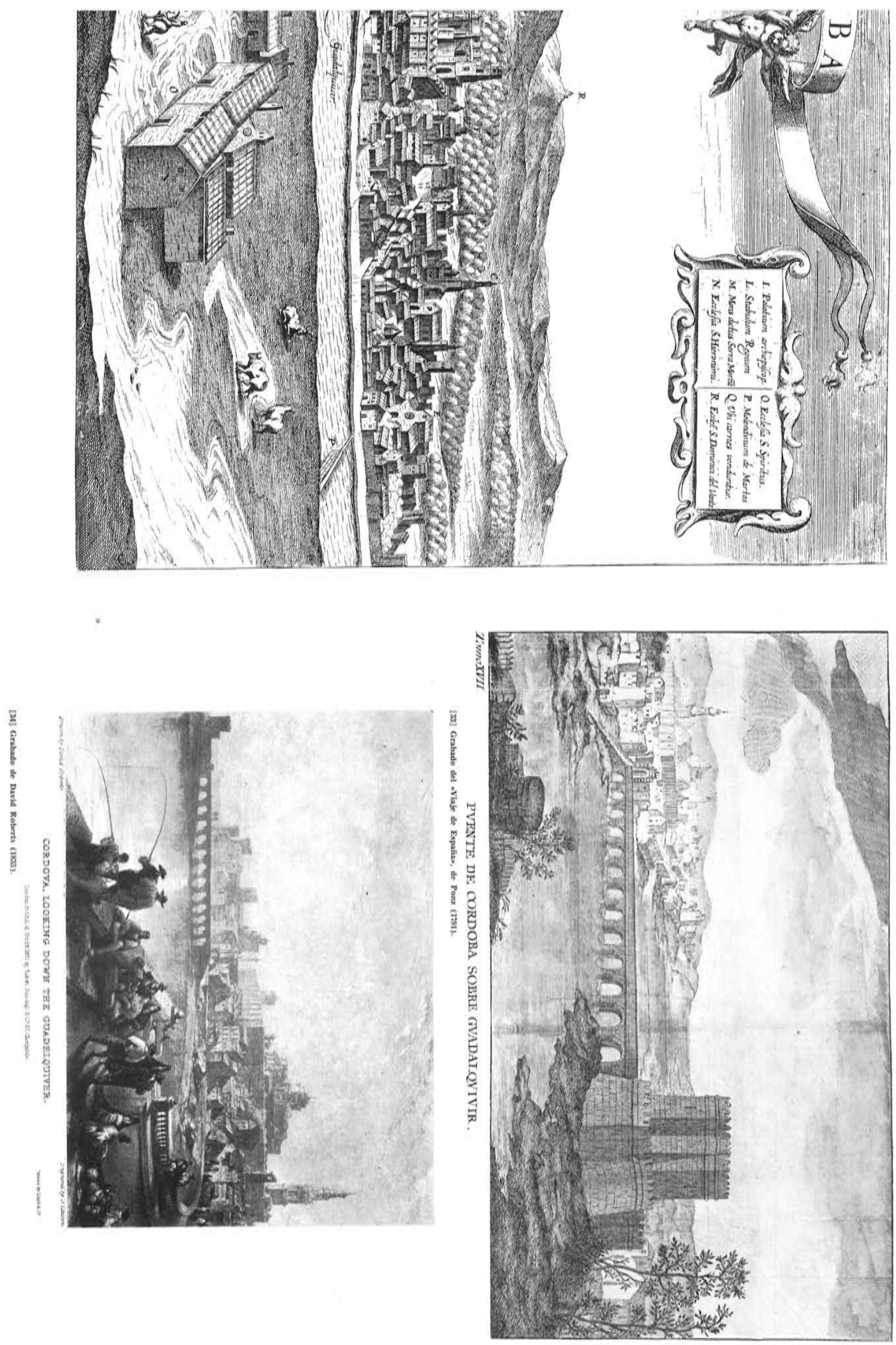

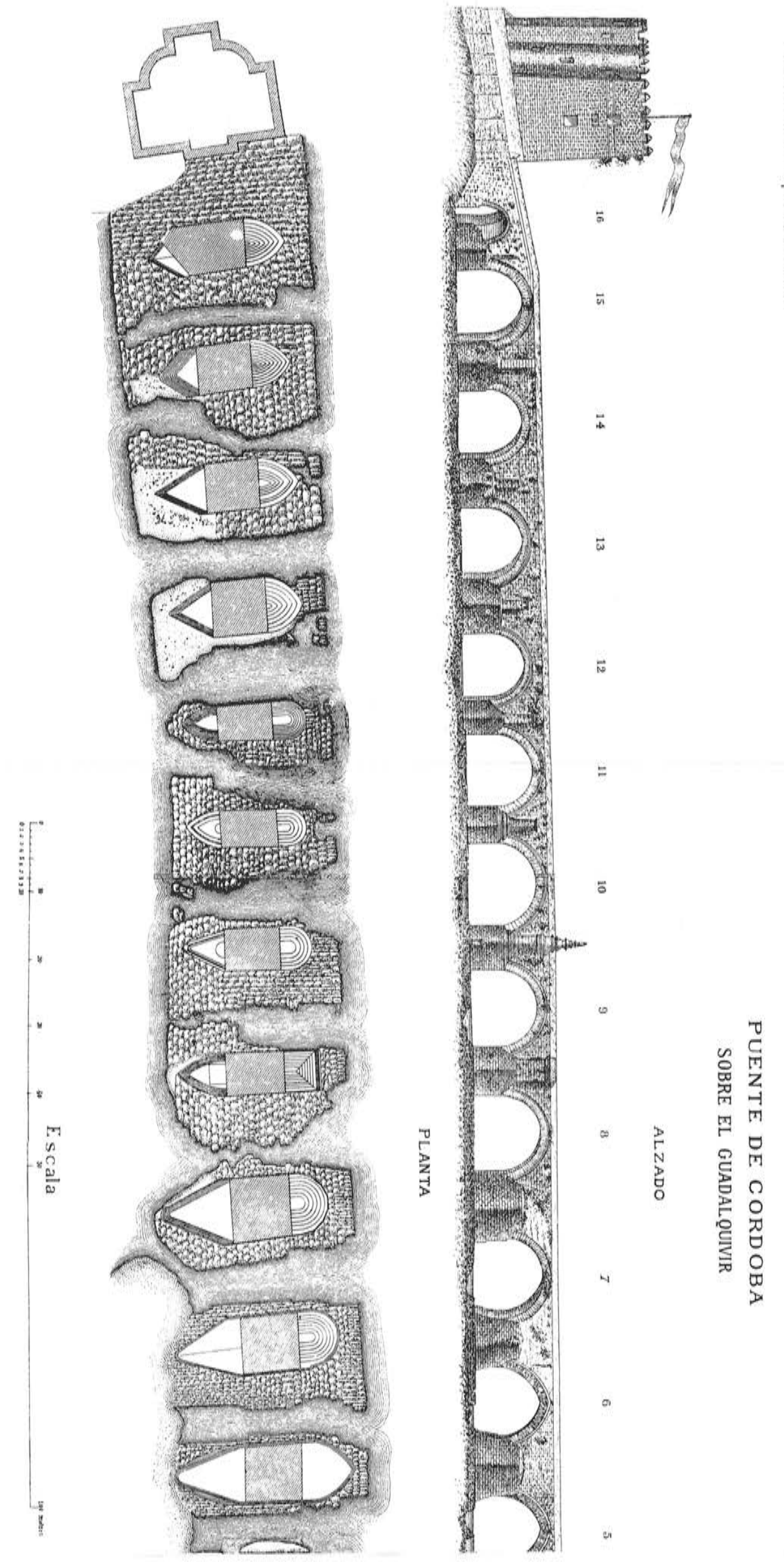

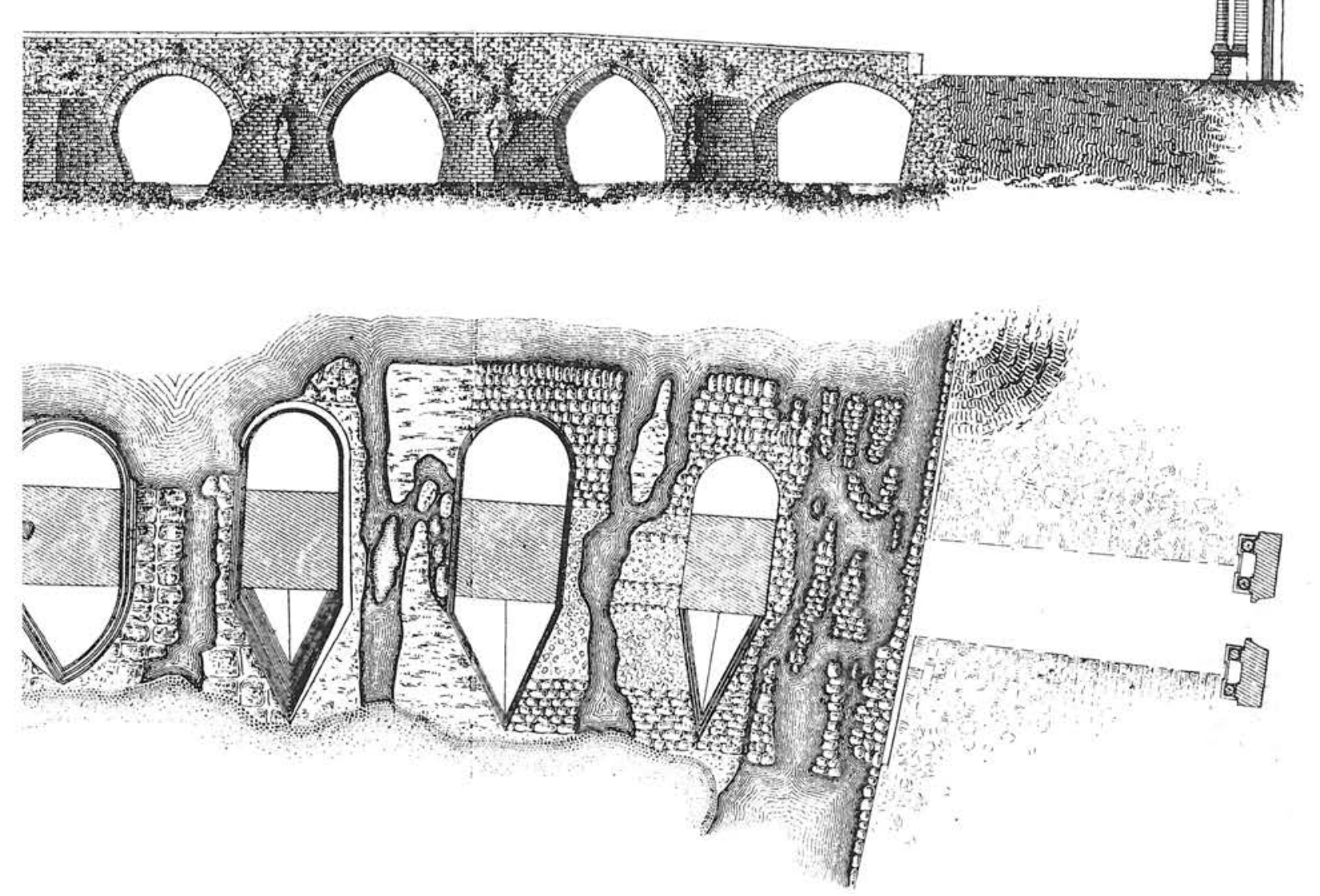

[31] Dibujos del Ingeniero Luis Sáinz y Gutiérrez (1894). 


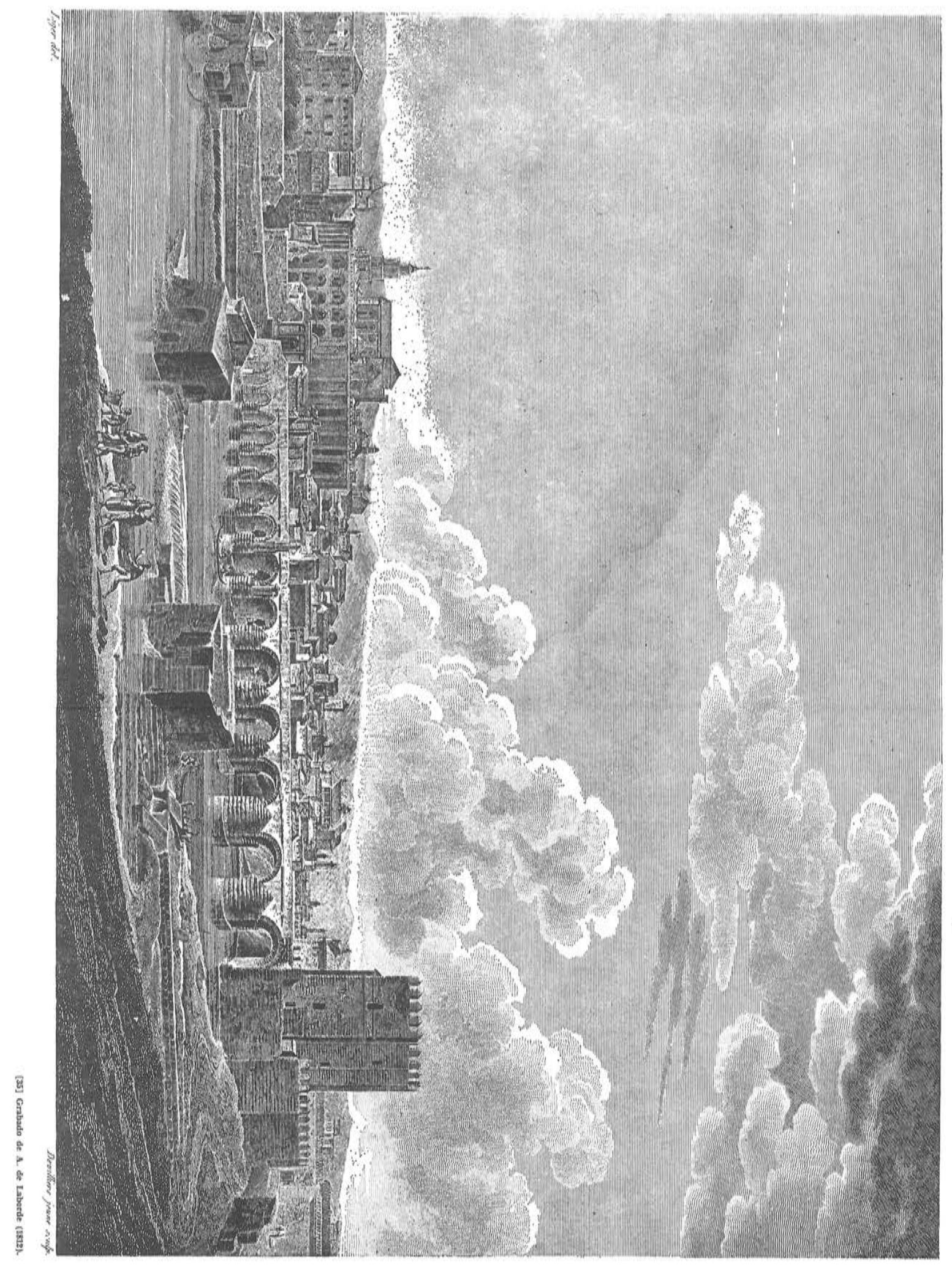




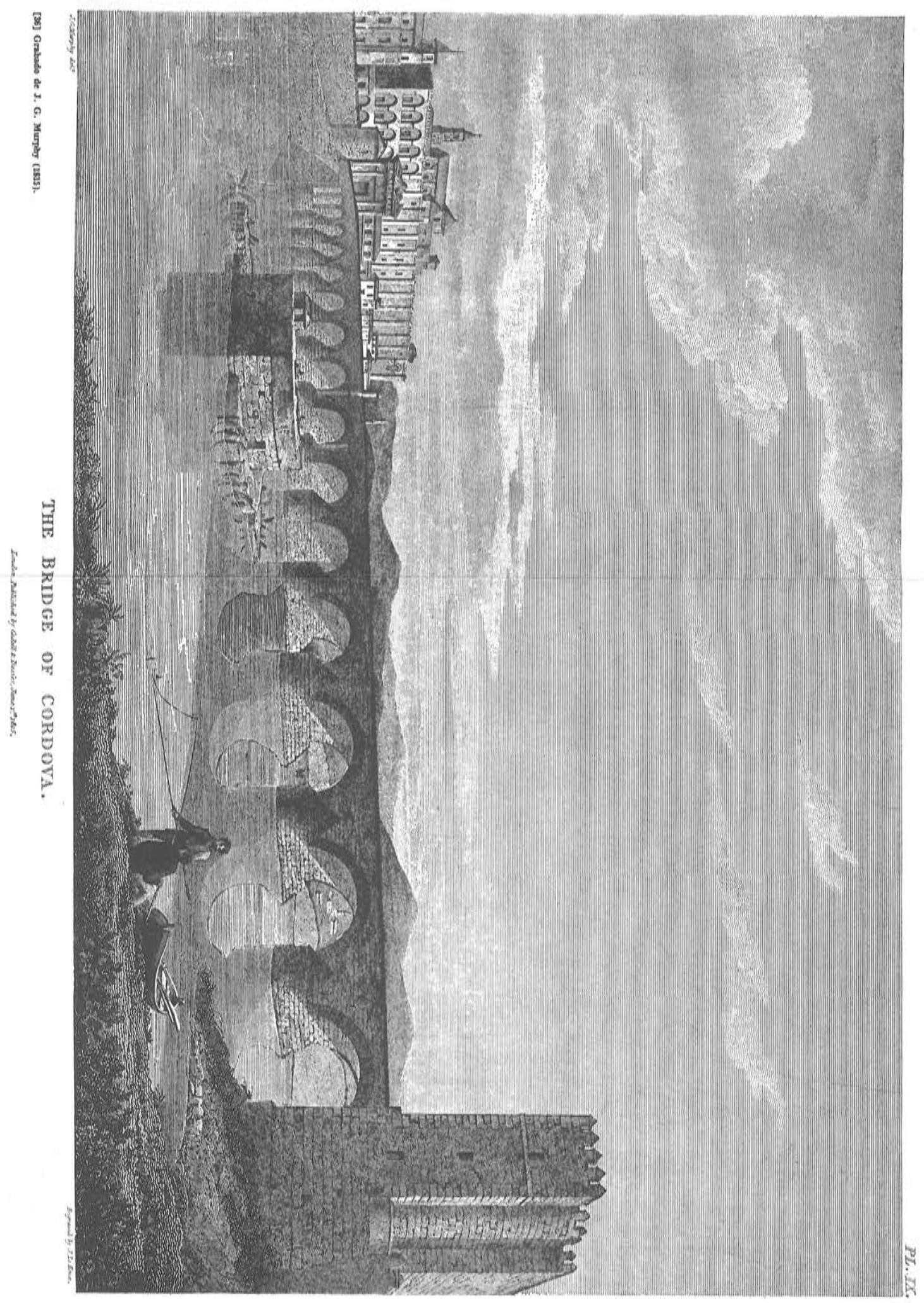




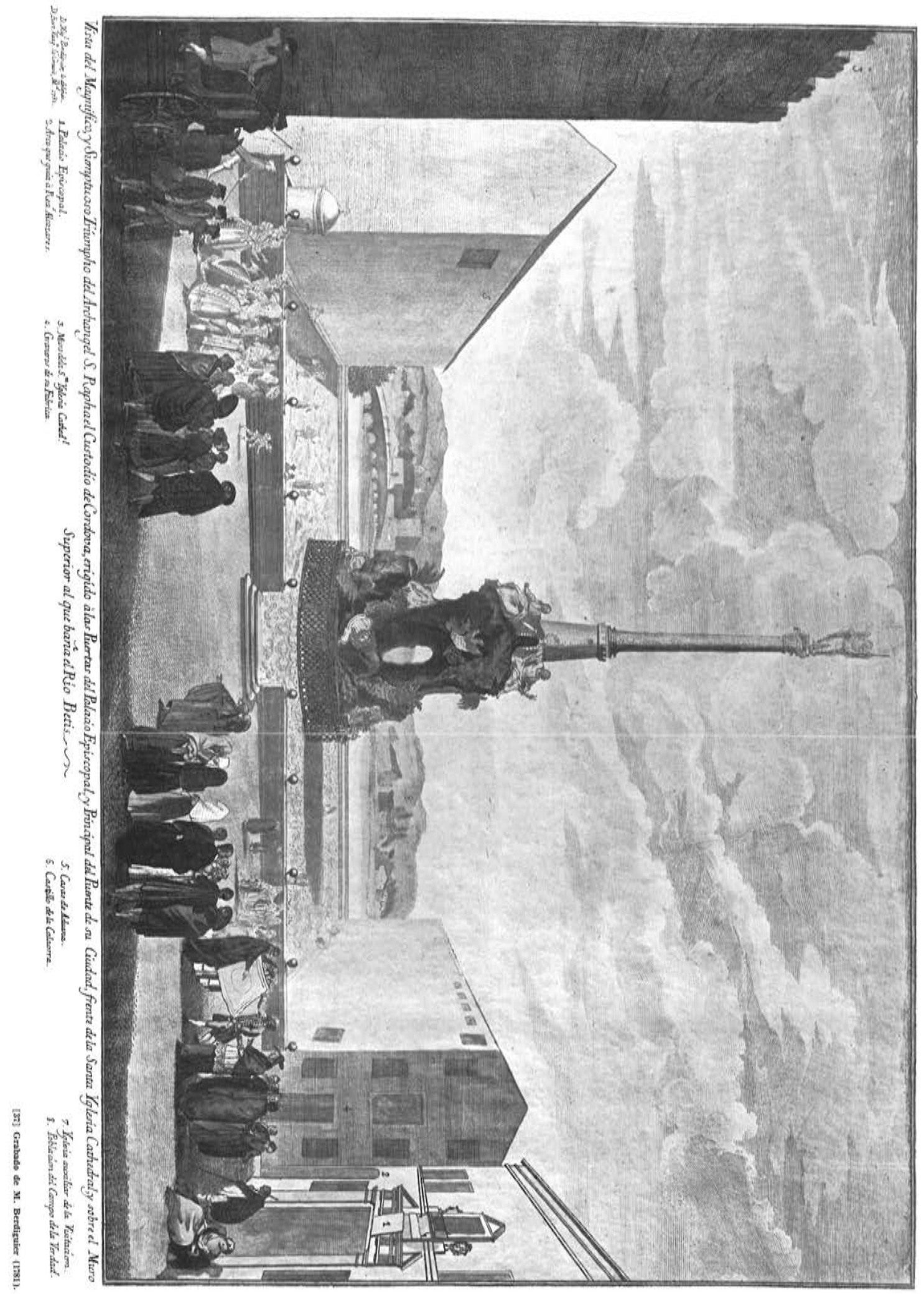




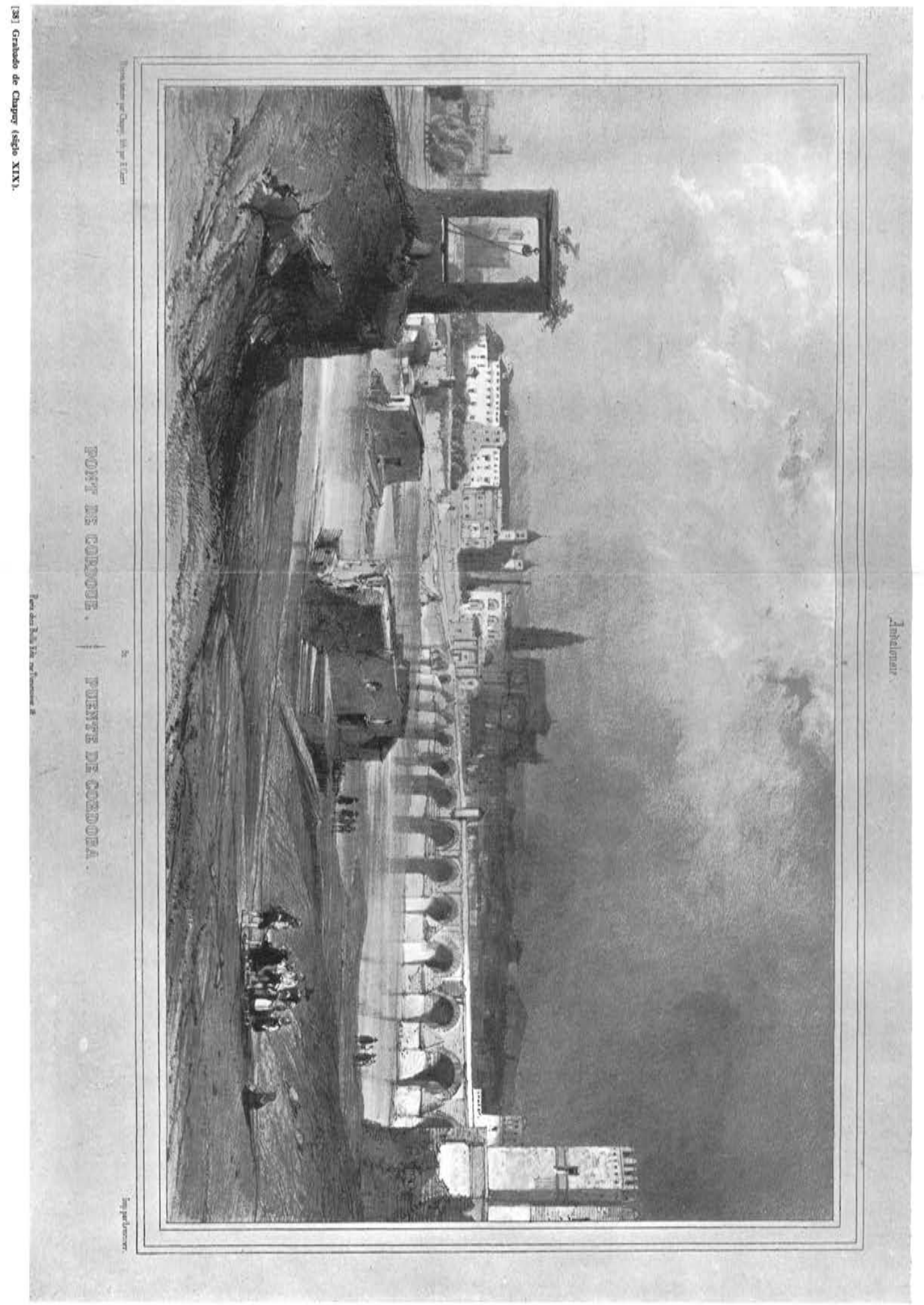




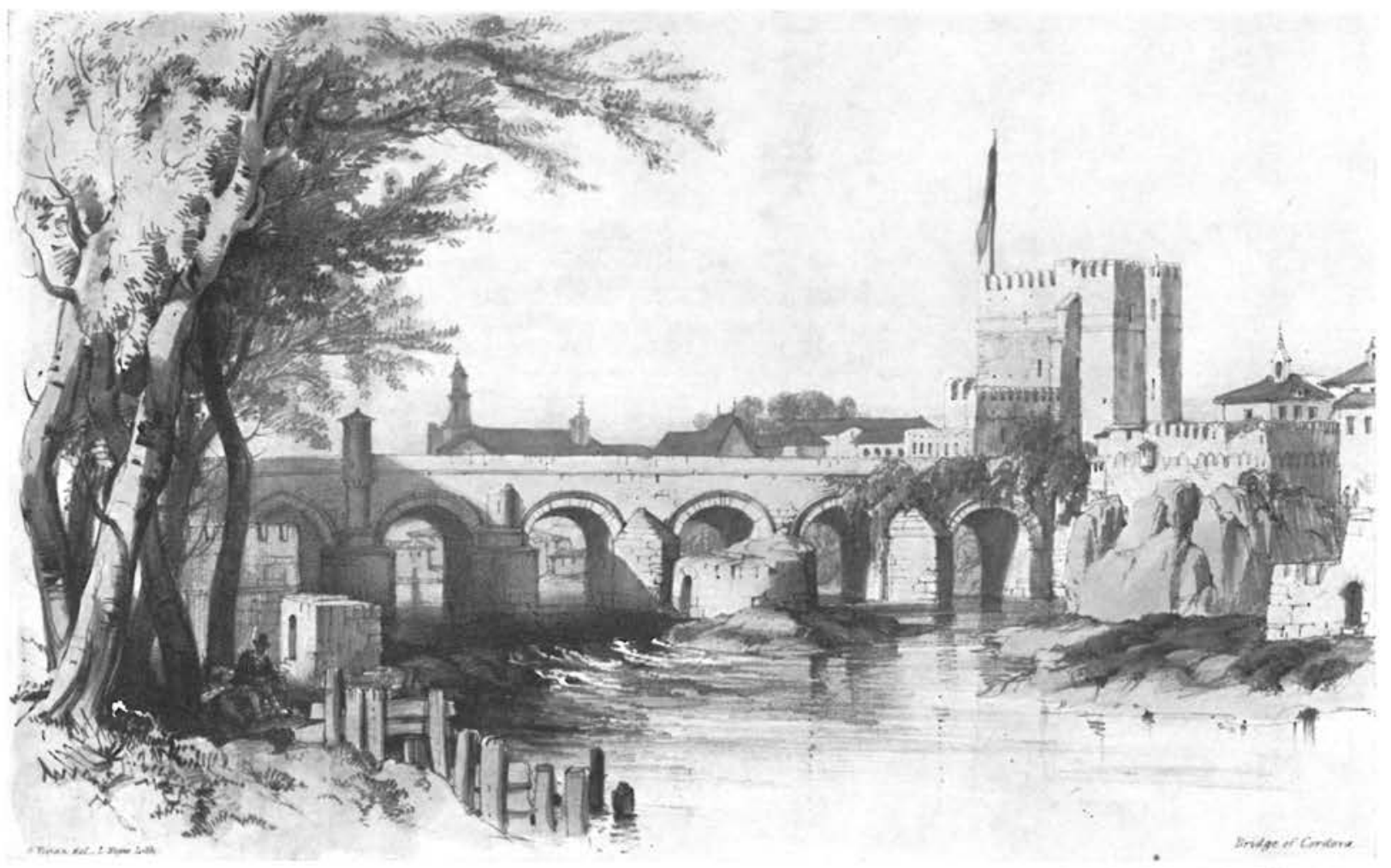

[39] Grabado de G. Vivian (1833).

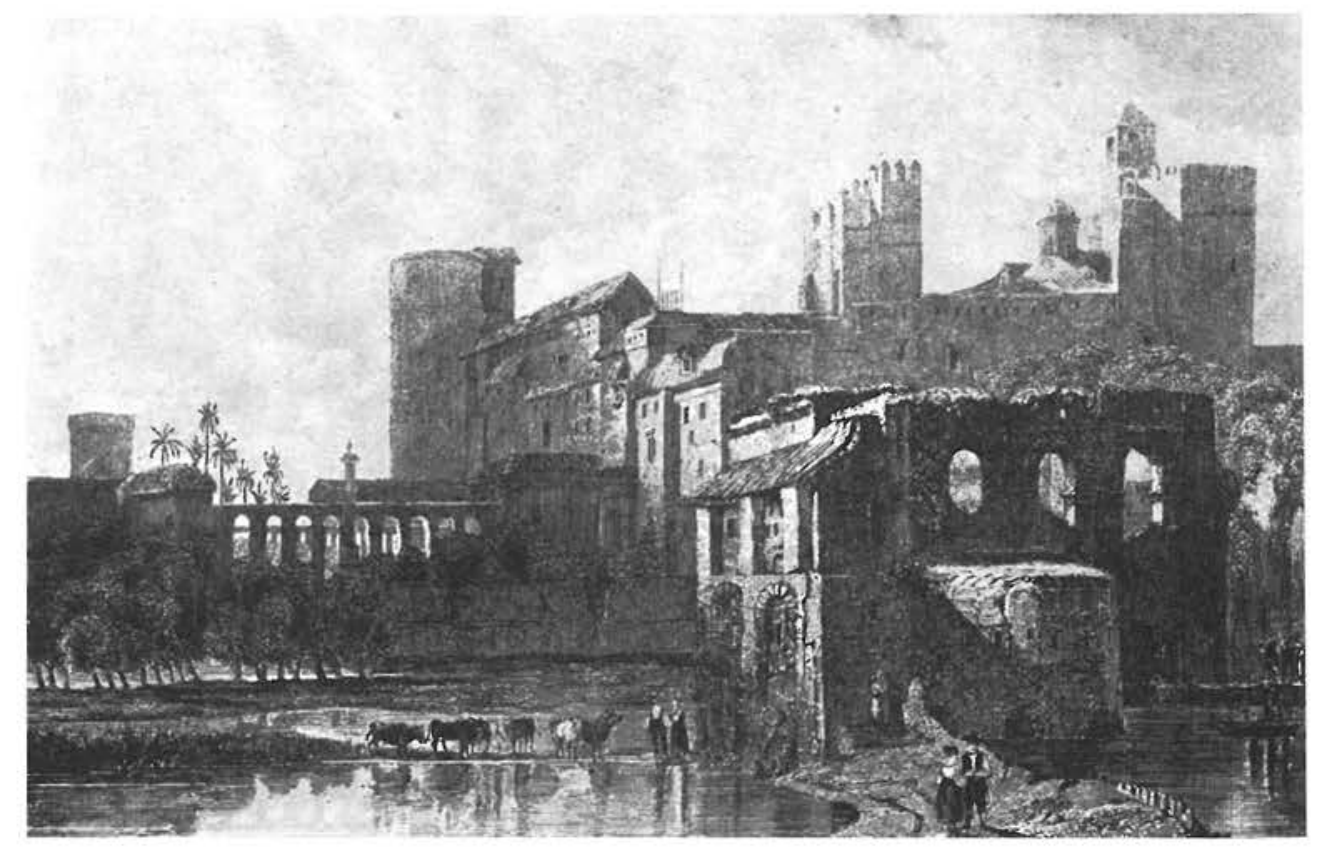

Prisan de ti Inquisition a Gordouel

Carcel de la lnquisicion en Cordoba

[40] Grabado de Lemaitre. 

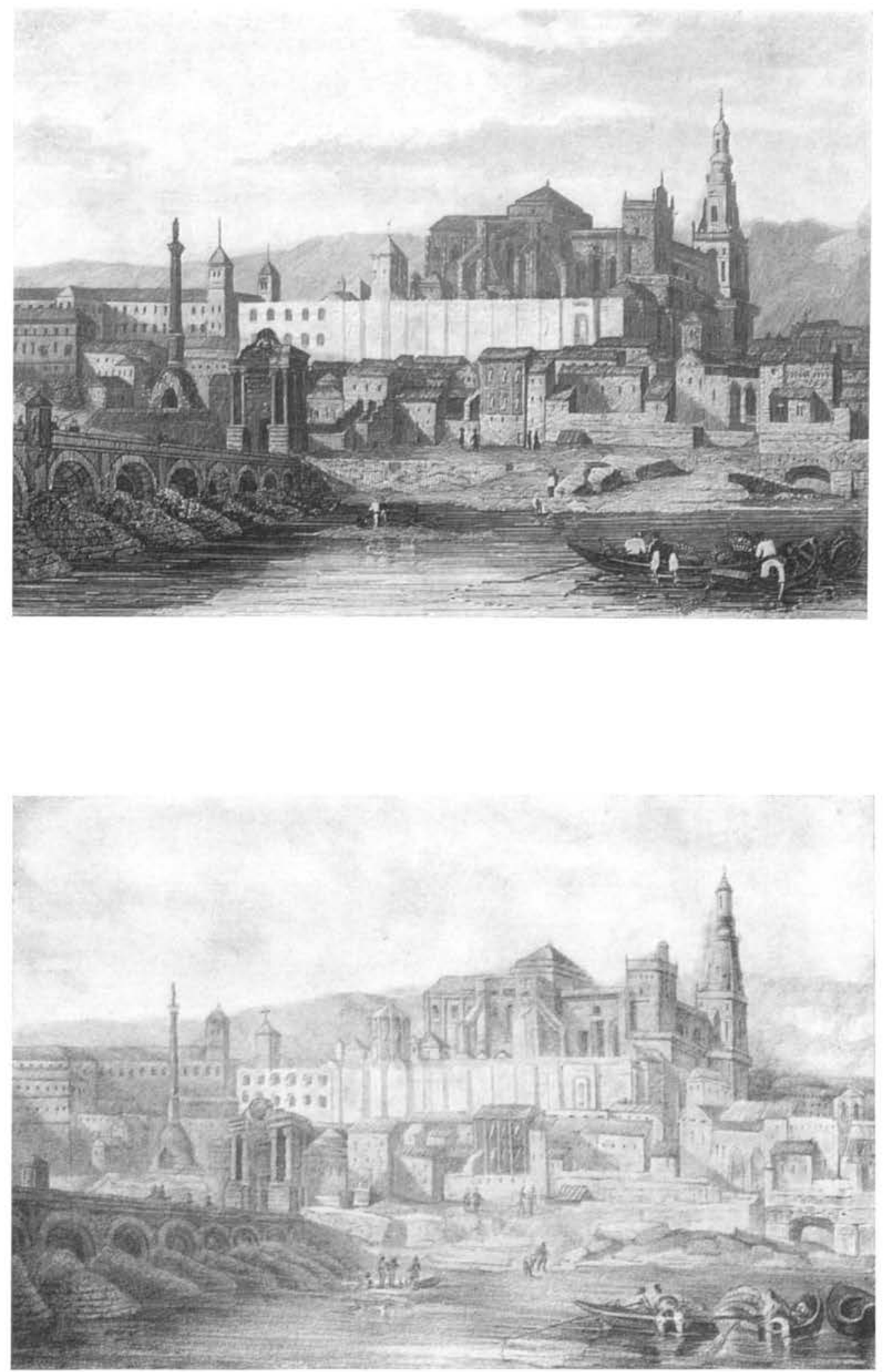

[41] y [42] Dos grabados del siglo XIX. 


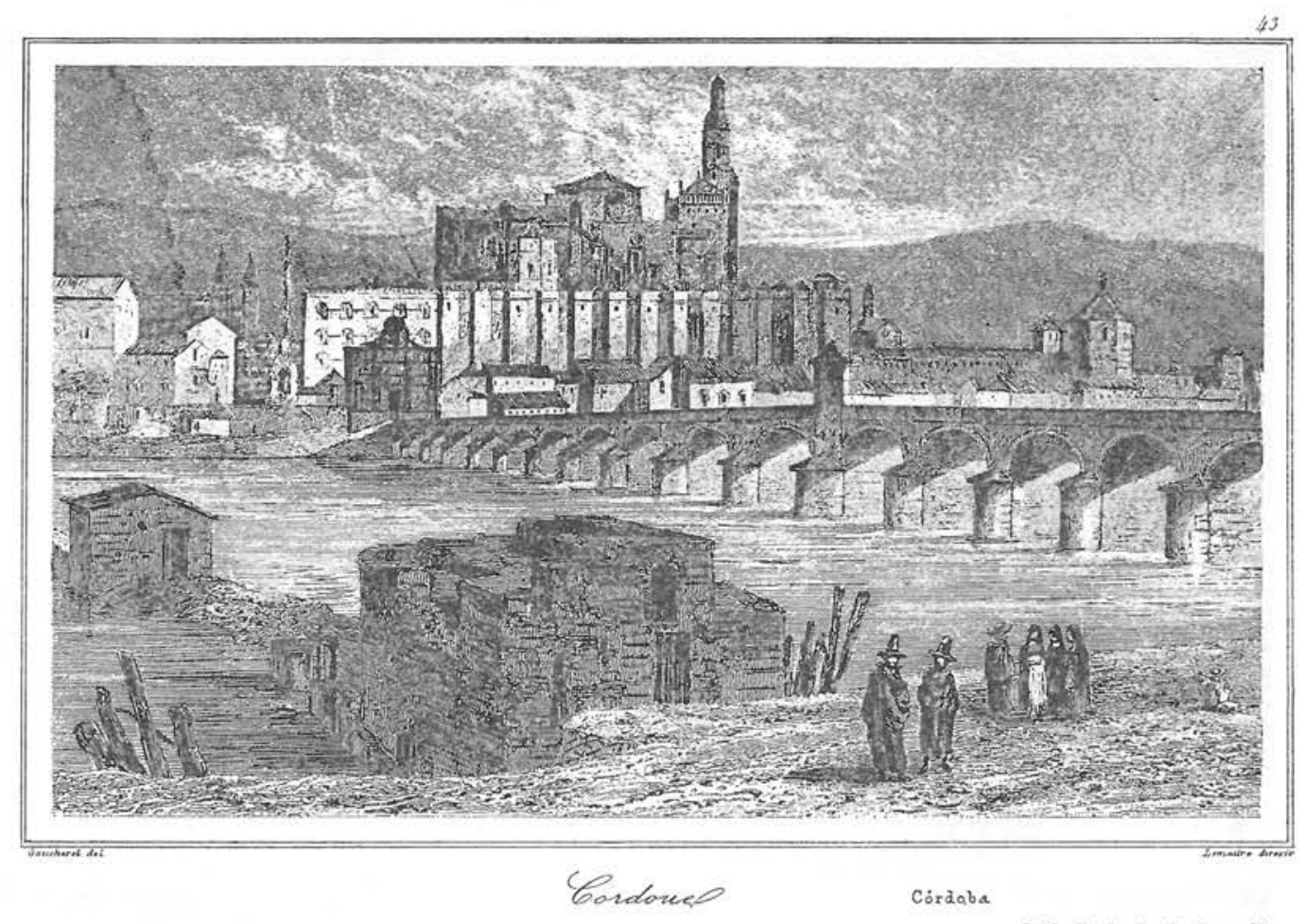

[43] Grabado de Lemaitre.

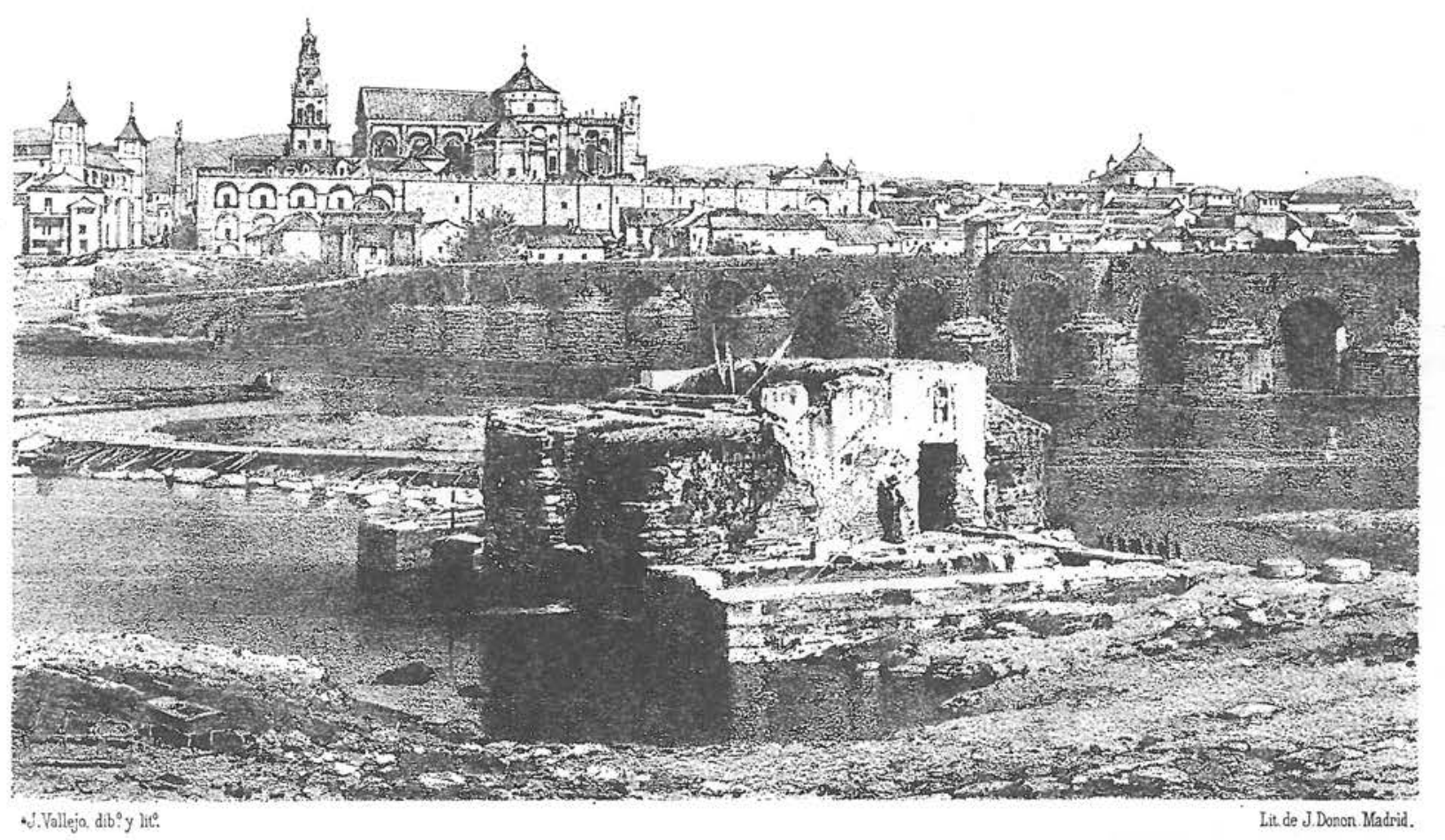

[44] Litografia de J. Vallejo. Siglo XIX. 


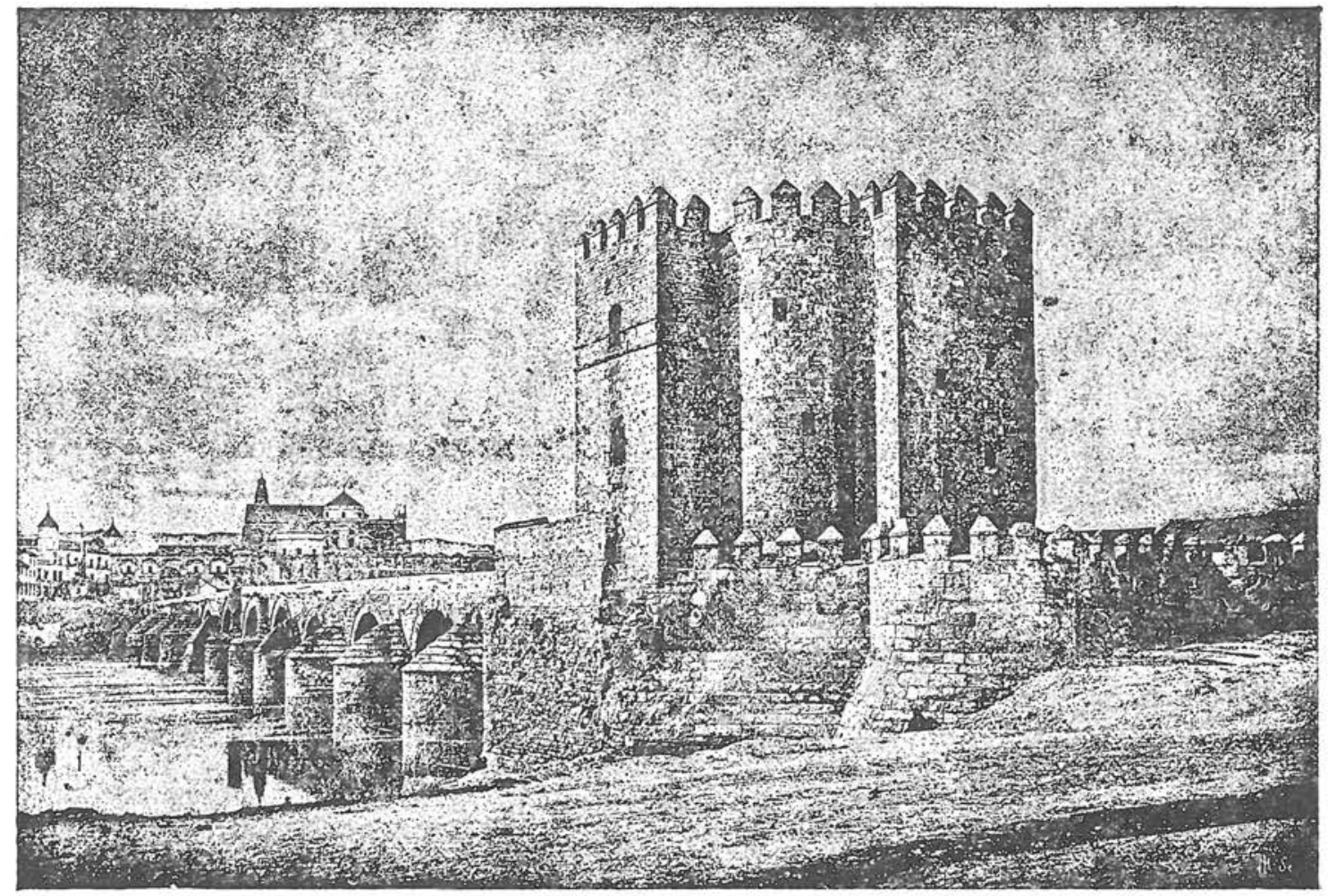

Castillo de la Calahorra y Puente

[45] Heliograbado de «España, sus monumentos y artes» (1886).

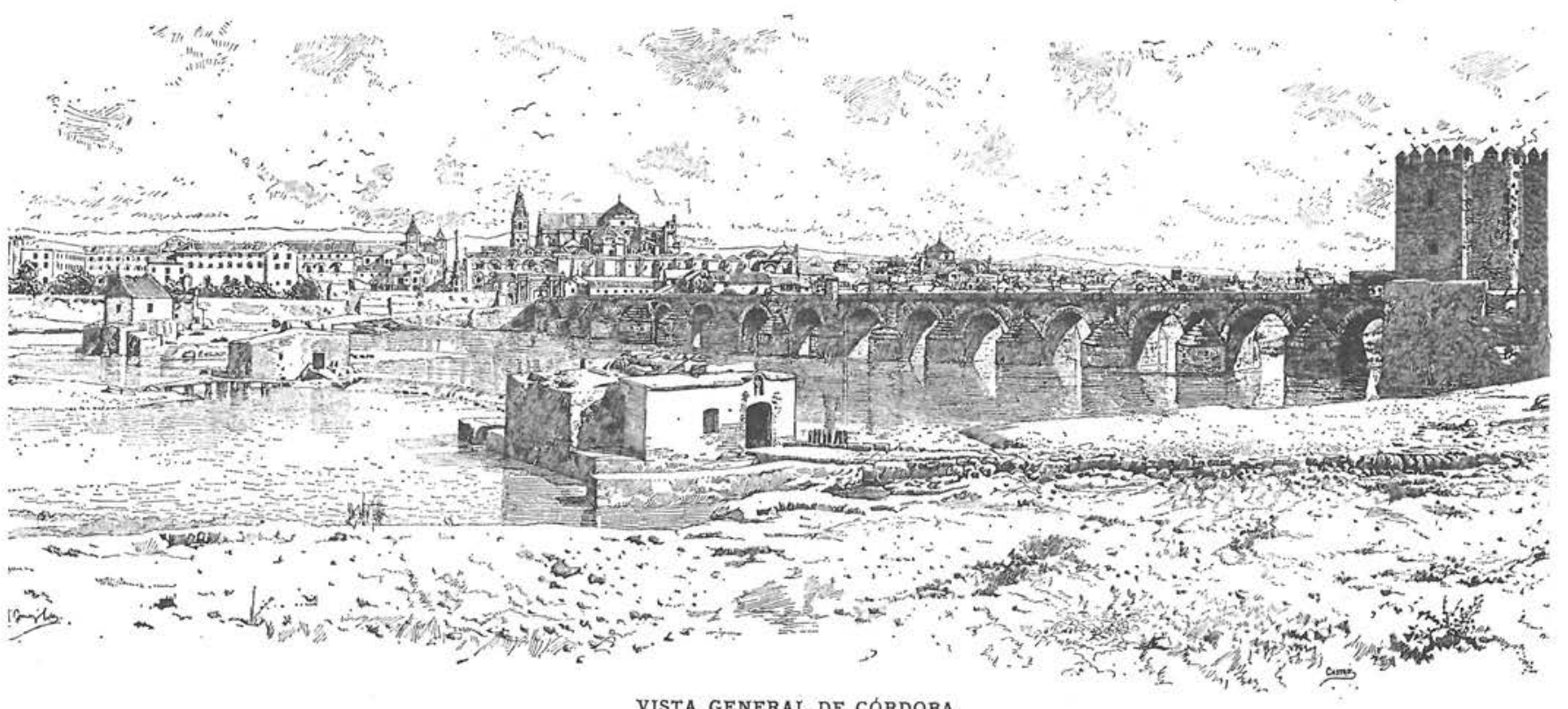

[46] Litografía de F. González. 
Las hacen pasar por un determinado número de ojos pero entran en el conflicto obligado con él en cuanto llegan a ser avenidas, pues se les ha mermado la superficie de paso y se les obliga a encauzarse por vanos más o menos inadecuados a su libre circulación, pero que producen contracción en la corriente con los aumentos locales de velocidad, es decir, poder destructivo, y además cambio de régimen desde la continuidad al de remolinos con el ataque directo a los elementos pétreos de la fábrica, y lo que es más grave al terreno del lecho menos resistente $\mathrm{y}$, por consiguiente, más erosionable y con una mayor trascendencia, ya que se mina la base de la construcción. Es una servidumbre del puente con sus fundamentos metidos en el río, fundamentos que producen ellos mismos las alteraciones que pueden serles fatales. La gran ventaja del puente actual en la superación de luces que le corresponde, estriba en exponer mu chas menos pilas a la corriente, a veces ninguna y, además, estas pilas son menos obstáculo en sí y mejor arraigadas en el lecho.

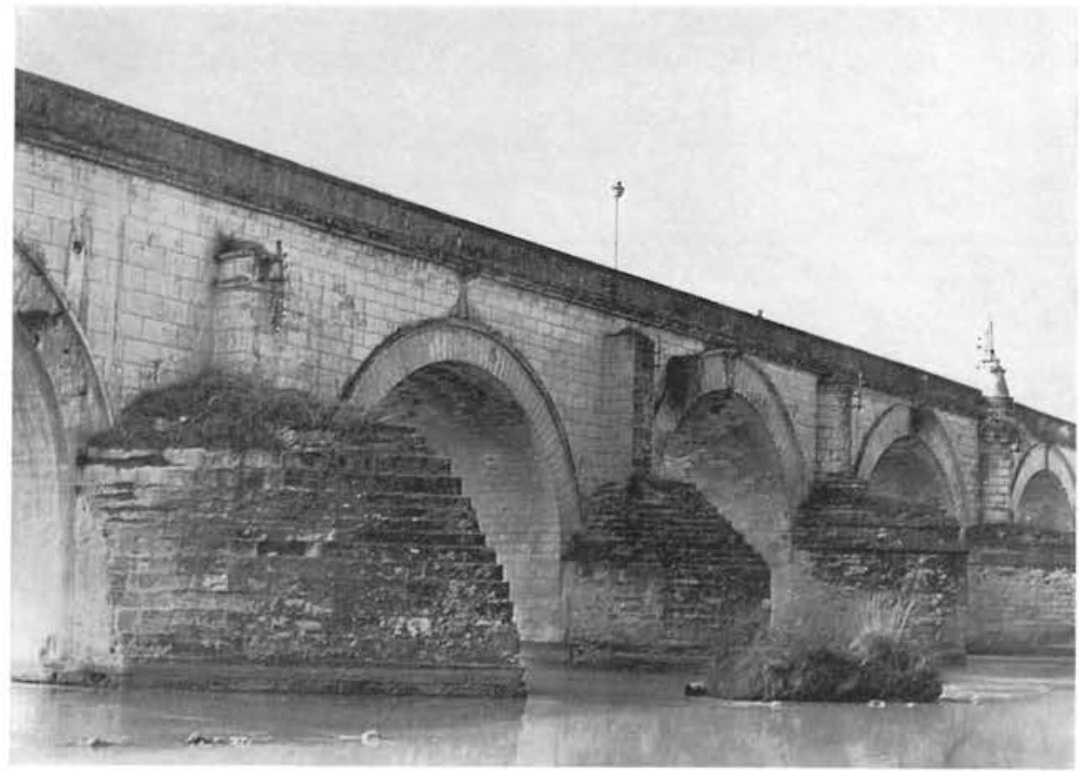

Arcos 12 a 9 desde aguas arriba.

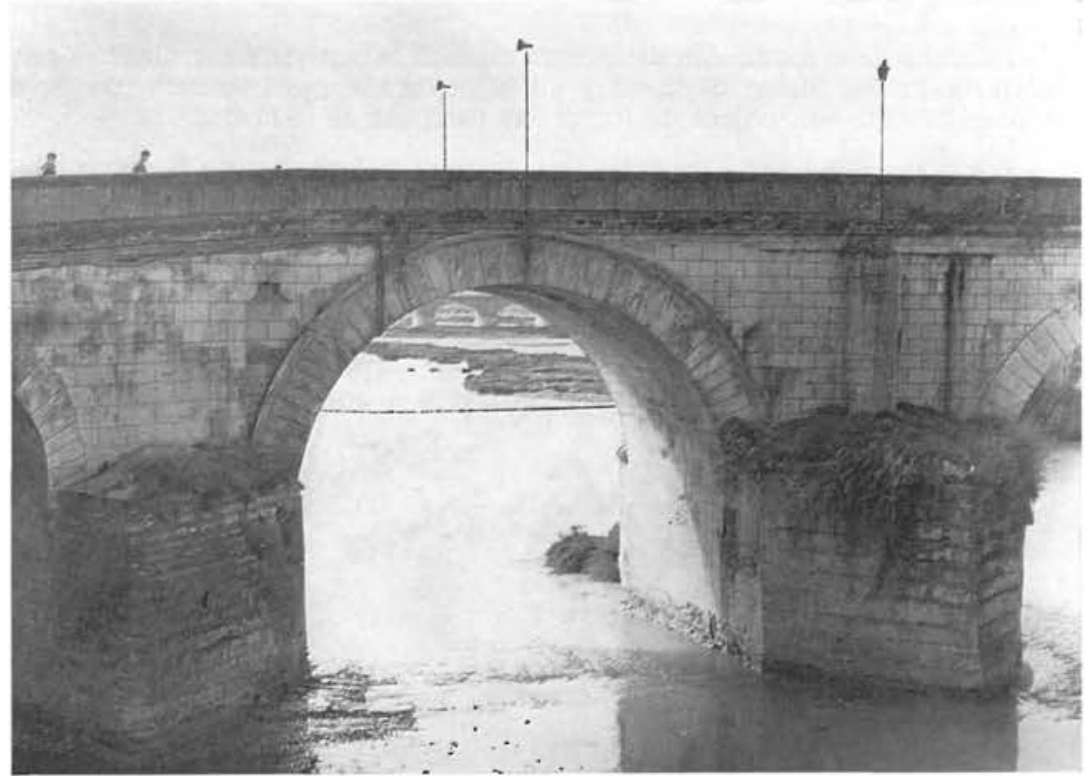

Arco número 15 desde aguas arriba.

Vista general desde aguas abajo y margen derecha.

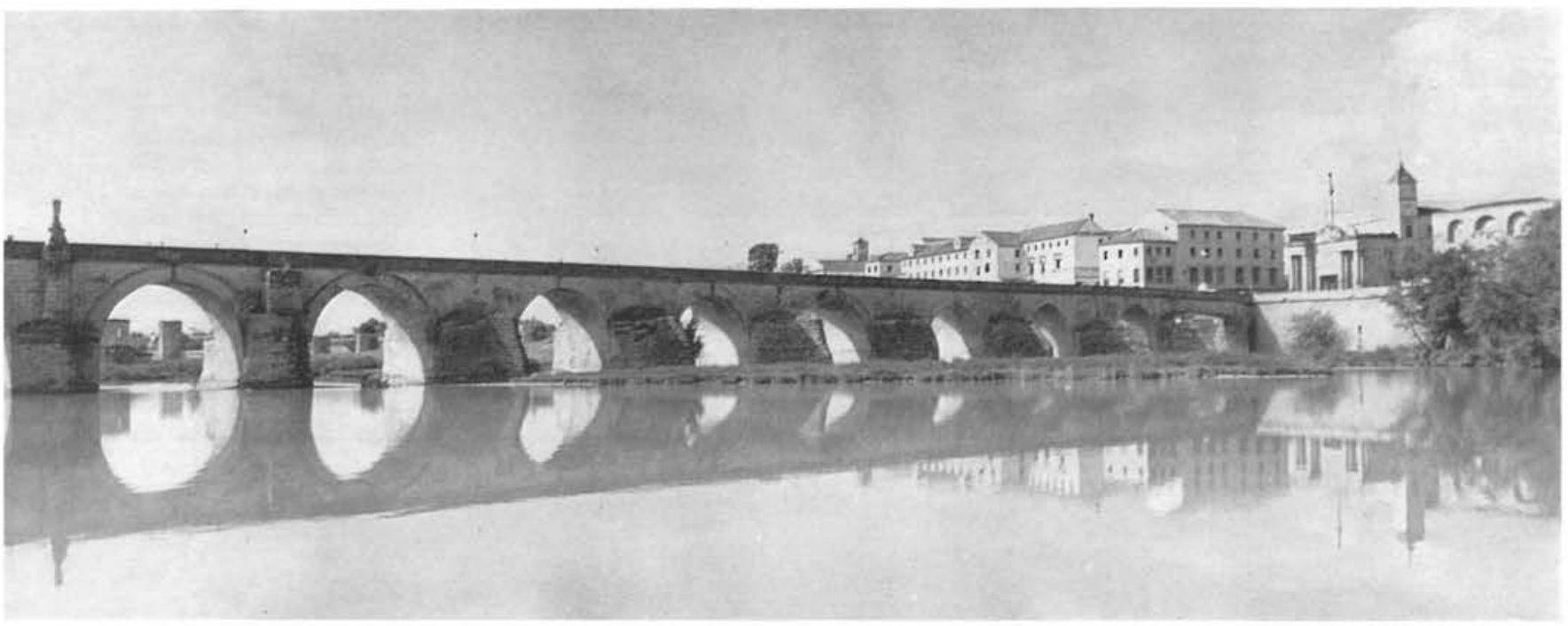




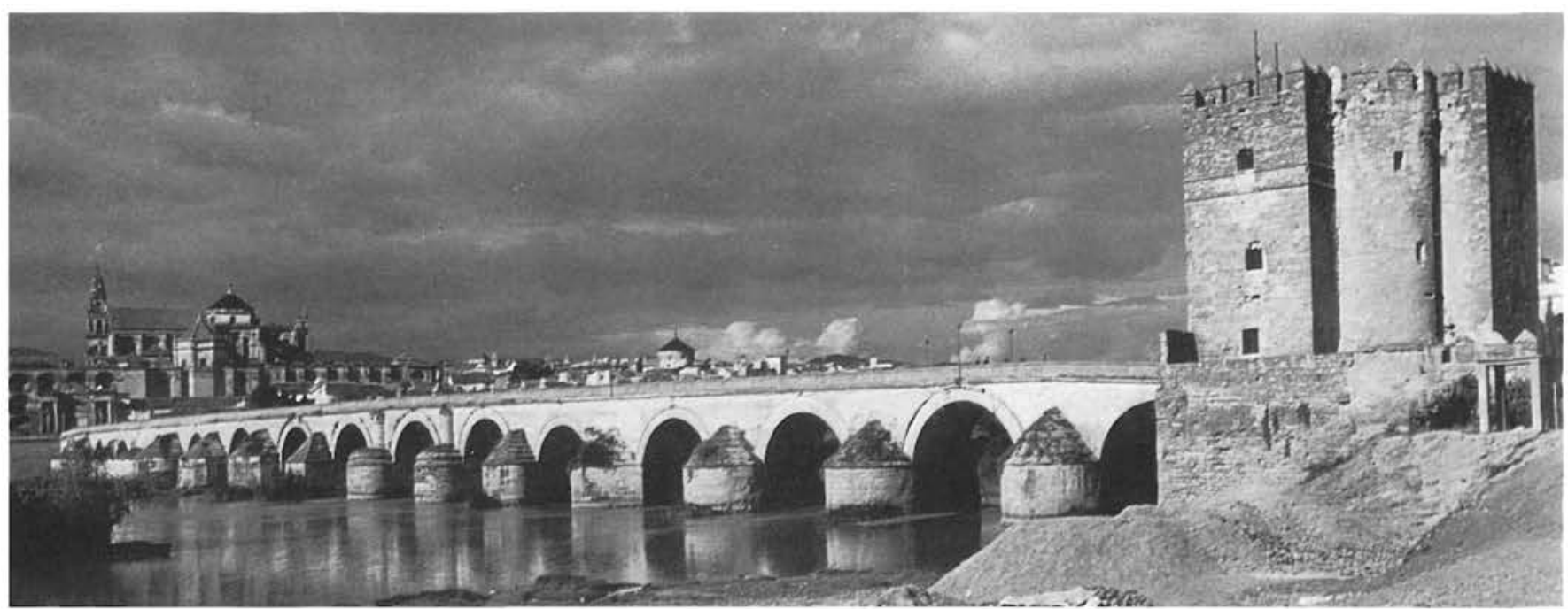

Vista general desde aguas abajo y margen izquierda.

La fecha de construcción del puente no está garantizada por ningún documento epigráfico, ni referencia literaria. En las luchas de César y los hijos de Pompeyo aparece con puente, pero pudo ser provisional y precisamente con objeto de forzar las defensas de la ciudad.

Por la magnificencia y los detalles estilísticos parece obra de la época de Augusto y además realizado de una sola vez, aunque las reconstrucciones hayan cambiado la fisonomía de algunos arcos. Es muy verosímil que tuviera un arco más del lado ciudad, que desapareció al ensanchar la calzada de la orilla derecha que siempre existió, y el muro de encauzamiento a lo largo de esa orilla.

Ya los romanos debieron realizar algunas reparaciones, aunque el zampeado general, que data de primera época, debió defender bien de la socavación las cimentaciones de las pilas. Lo que sí resulta casi seguro es que los visigodos dejaron el puente en condiciones de mal uso, siendo necesarias sucesivas reparaciones de los musulmanes para conseguir su utilización, empleando sillares de la muralla antigua y aun ladrillo. Una reparación importante fue

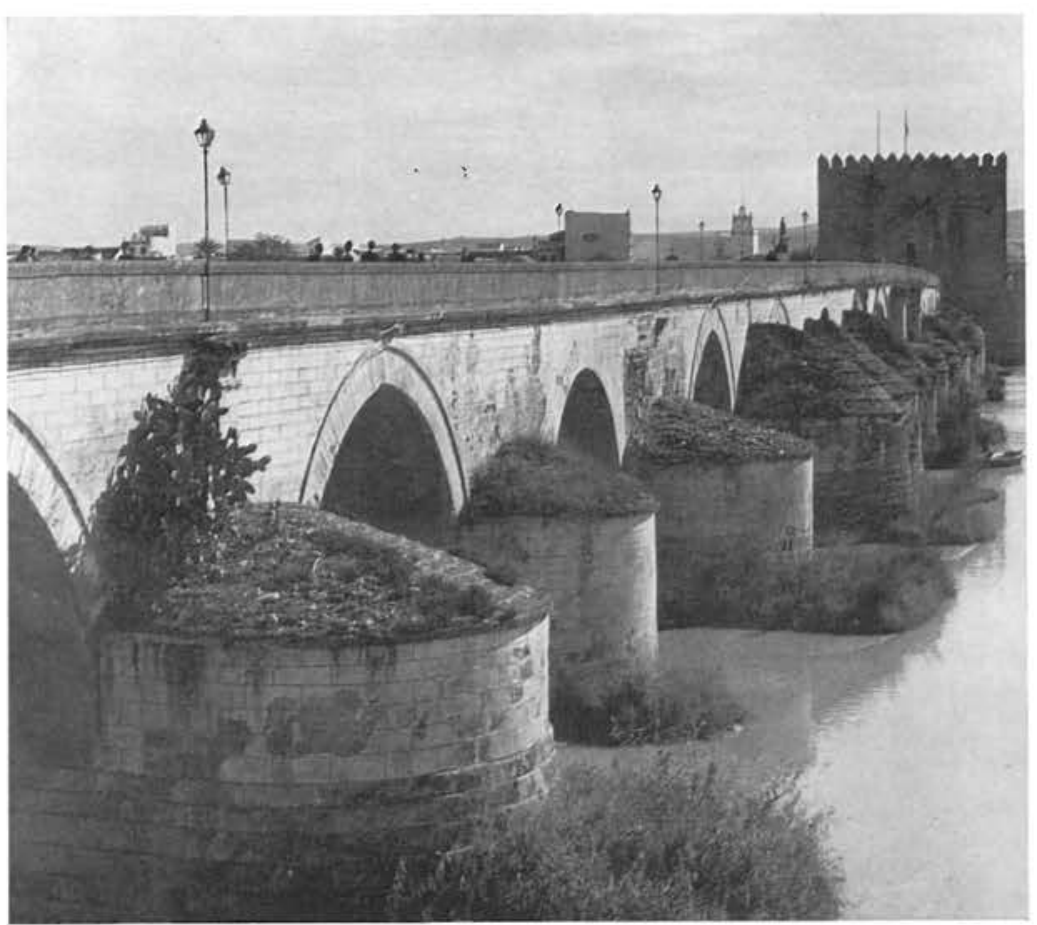
la de Histiem I, en el 789 , en la época de grandes construcciones de la ciudad, entre las cuales figura una ampliación de la mezquita. De estas reconstrucciones, así como de las que se hicieron posteriormente hasta nuestros días, nos ocupamos a su tiempo, utilizando el magnífico trabajo ya mencionado del Ingeniero de Caminos Luis Sáinz Gutiérrez.

Así, quedó la muralla delimitando el recinto de la ciudad unos 800 metros a lo largo de la orilla derecha del río, con una sola puerta en la alineación de ésta, que se denominó puerta del Río. Del otro lado la calzada que salía de ésta se bifurcaba con una hacia Sevilla por Ecija y otra hacia Elvira.

Arcos del lado ciudad. 
Castillo de La Calahorra. Vista desde el castillo.

Triunfo de San Rafael.

Para los musulmanes era una obra pía trabajar en la reparación de puentes. Hay documentalmente un cierto número de reparaciones; pero nunca se sabe en qué consistieron, pues resulta tópico que el que pone una pequeña parte la amplíe en los documentos con todo el énfasis que pueda, para lo cual generalmente no se hace constar lo realizado. Es preciso recurrir a documentos de archivo y examinar las cuentas desmenuzadas en capítulos y asignaciones para poder determinar cuál es su verdadera aportación, que resulta ser mucho menor que la que cómodamente se consigna en inscripciones y documentos simples. Así el énfasis puede llegar a atribuirse la obra total a costa de una corta reparación, y así ha existido la teoría de que el puente con que tratamos actualmente se debe a los musulmanes, que se lo encontraron completamente arruinado, pero basta que se destruyan varios arcos y alguna pila, no uno sólo, que se repone fácilmente con madera, para que se inutilice la obra.

En la Edad Media las reconstrucciones de musulmanes y cristianos eran obligadas, pues la Reconquista tuvo que suponer la destrucción de algún arco. En cualquier conflicto este puente completa la organización defensiva de las murallas, convirtiéndose en puente levadizo al destruir un arco, que sería siempre el mismo, probablemente el inmediato a la ciudad.

En la Edad Media tenemos ya referencias más directas gracias al estudio documentado del ingeniero Sáinz.

\section{Problemas arqueológicos}

El puente de Córdoba plantea un problema que ya hemos tocado en los puentes más importantes que han pasado hasta ahora por nuestros artículos: es una entidad con una construcción inicial, en nuestro caso, romana, sin género de duda, pues aunque los romanos no inventaron los puentes, los que se construyeron anteriormente no han tenido posibilidad de pervivencia hasta nosotros. Esta entidad va
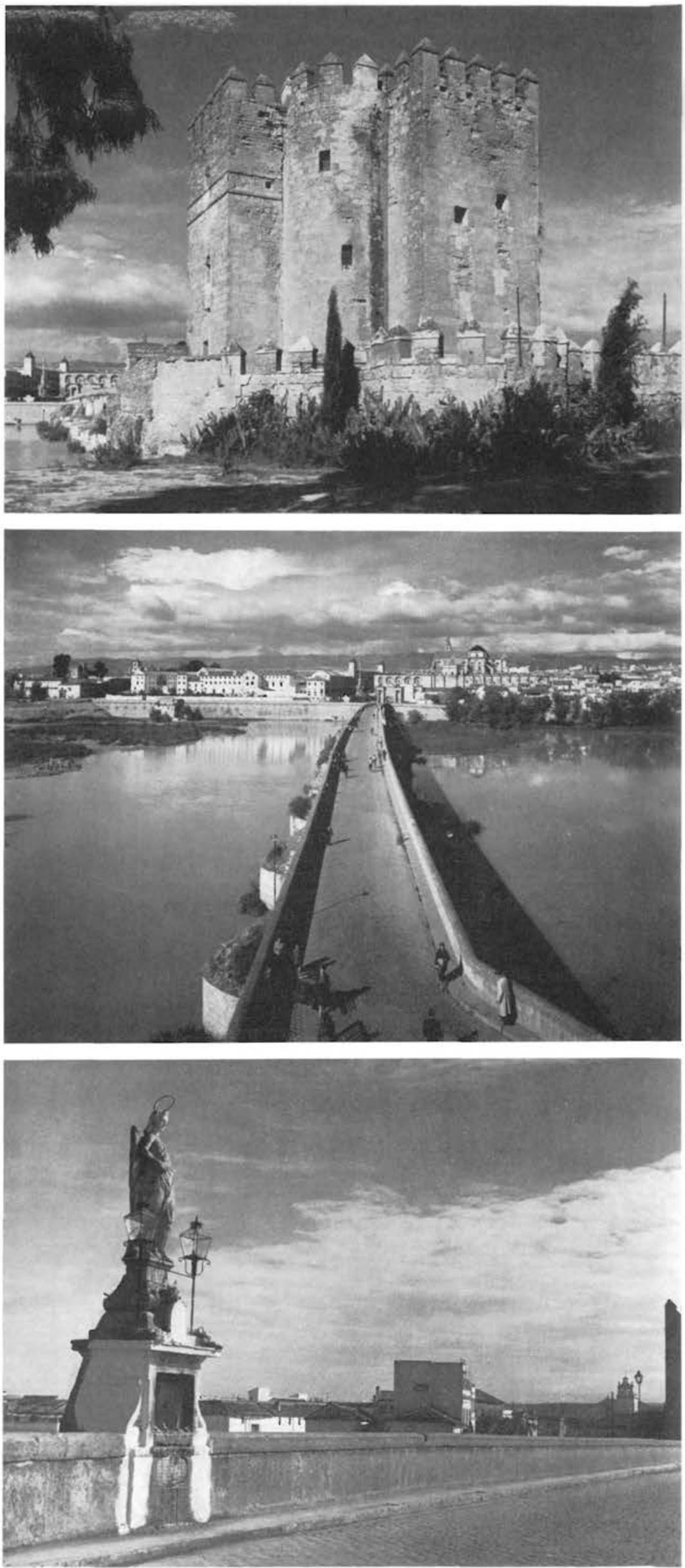

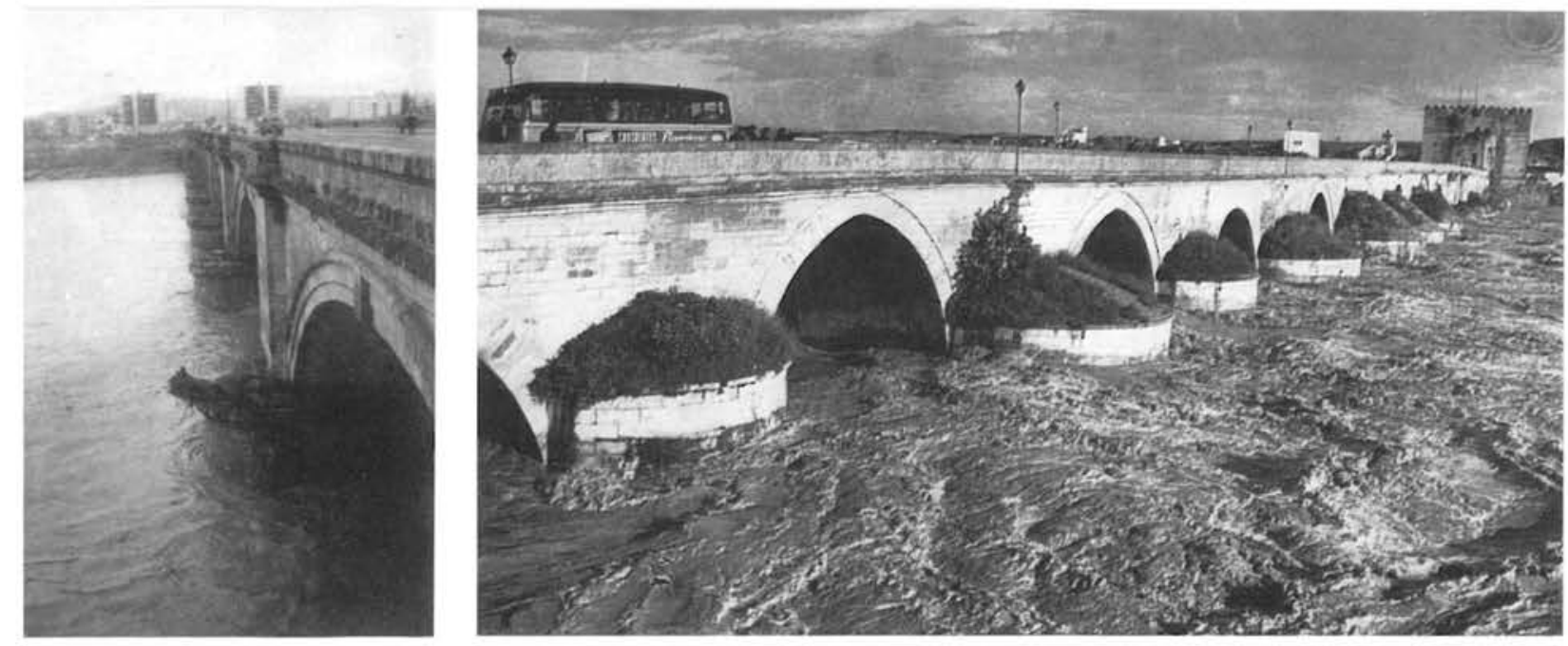

Aguas abajo desde la ciudad.

Vistas del puente durante las últimas avenidas.

transformándose históricamente por necesidad de regenerar las destrucciones que el ataque continuado de la corriente normal va produciendo en pilas y cimentaciones, ataque acentuado en etapas cortas, pero mucho más violentas, que además dejan la obra, especialmente en sus cimientos, más vulnerable a las condiciones normales de agresividad del río, a lo cual hay que añadir la actuación esporádica, pero más eficaz del hombre destruyendo por necesidad o barbarie algunos de los elementos esenciales de la obra. También, aunque en este caso de puente romano es menos importante, tenemos el propio uso de la obra, desgastándose materialmente por el roce de las ruedas comiéndose la superficie de rodadura, rom. piendo alguno de los elementos desgastados, o por choques producidos a causa de las discontinuidades en la superficie. Este ataque local de elementos con pesos comparables, carro y sillar, puede llegar a desarticular la trabazón necesaria en los elementos vitales, que son los arcos. Pero, sobre todo en los puentes romanos, el peligro viene de abajo, de las cimentaciones, que unas veces ceden desde el principio a lo largo del tiempo y otras bruscamente por disminuir la sustentación al ser socavadas.

La obra, sin duda alguna inicialmente romana, va cambiando de entidad, algunos sillares se deterioran por las acciones que hemos enumerado, a veces son elementos más importantes como una pila que asienta o se inclina, o un arco que se articula primero y luego se rompe al asentar estas pilas o volcarse al actuar los empujes sobre un elemento deficiente en cuanto a estabilidad.

Esto ocurrió desde el principio y cuando todavía los romanos eran los "propietarios» de la obra y ellos mismos reponían los sillares deteriorados, recalzaban los cimientos disminuidos, rellenando los huecos que había producido la erosión, bien en el terreno de asiento, bien en la
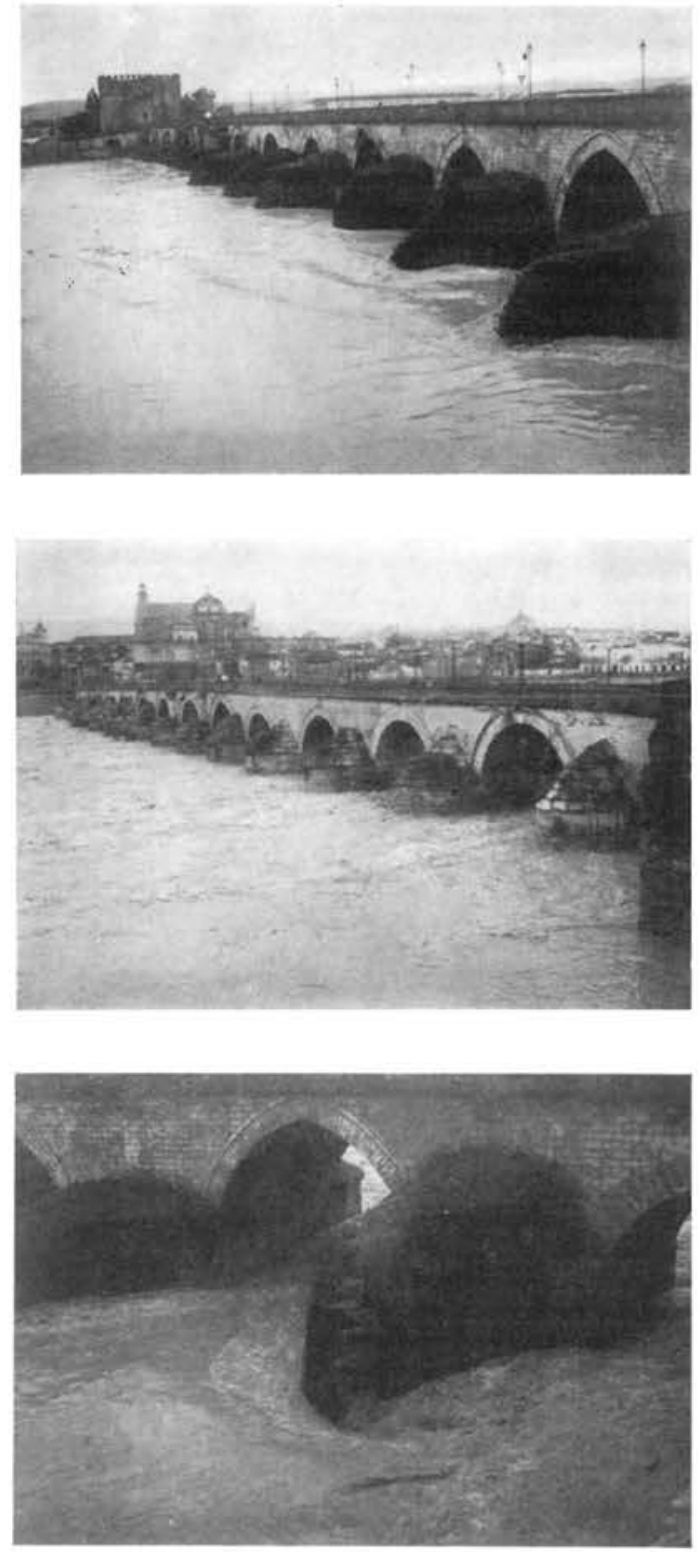


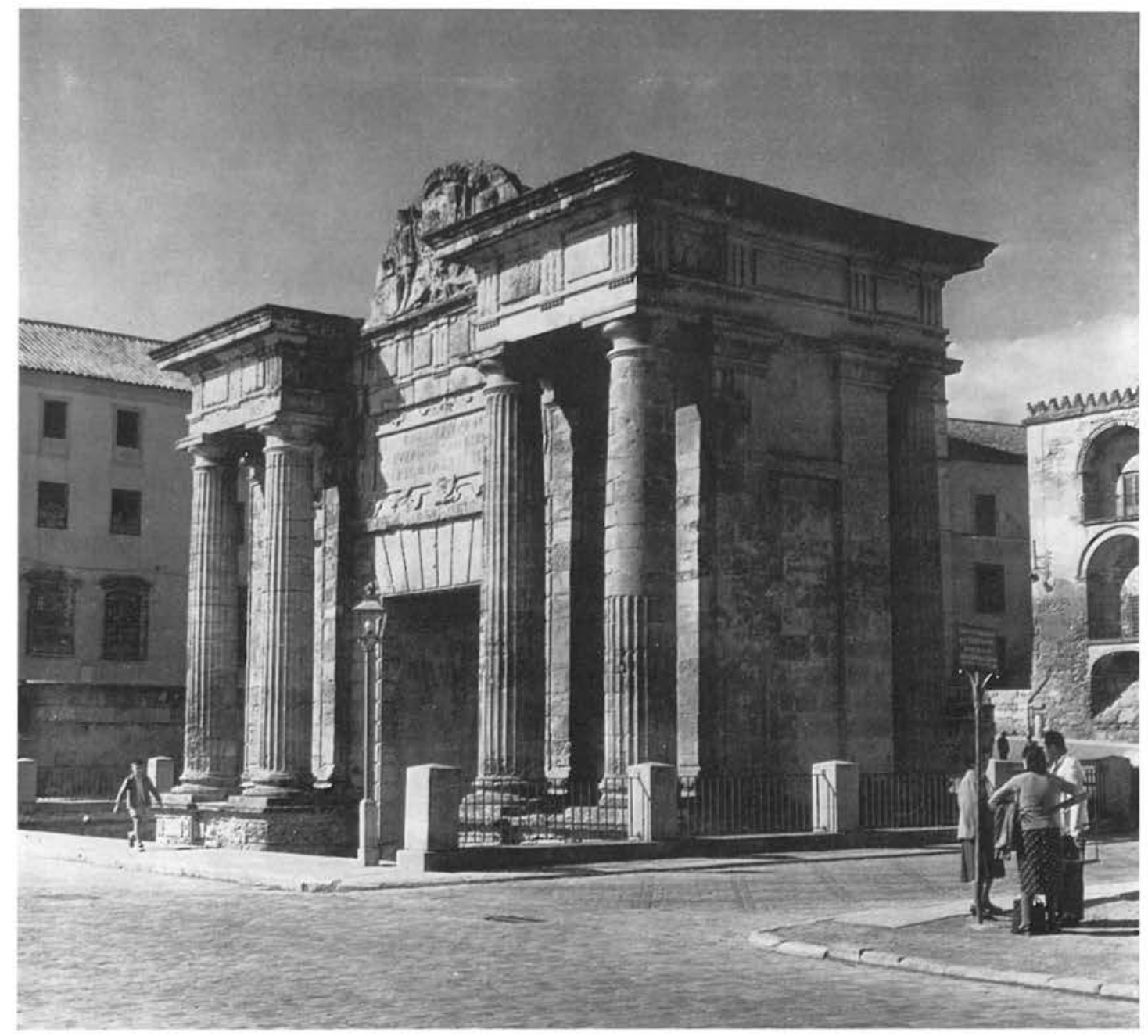

Puerta del Puente. Siglo XVI.

propia obra; reconstruían los elementos estructurales, arcos o arcadas completas; en ciertos casos desmontaban y volvían a montar un grupo de ellos dejando la obra en condiciones casi análogas a las primitivas, pues las pilas variarían poco de forma y los arcos serían también de medio punto con todos los sillares anteriores o algunos nuevos, pero conformados en la misma agrupación. En estas condiciones, y sin género de duda, podemos decir que el puente sigue siendo auténticamente romano, pues son romanos sus constructores y el proyecto con pequeñas reformas es el mismo.

El problema teórico se complica cuando los romanos han pasado y nos encontramos ya con los visigodos o con los musulmanes. Si no hay variaciones en la forma de las pilas o de los arcos, lo cual muchas vecse es lo más fácil ya que normalmente pueden recuperarse algunos sillares y además tienen como pauta para la reconstrucción los otros arcos que no han fallado y que con su presencia son mucho más útiles que cualquier silueta trazada sobre plano. Entonces el diseño sigue siendo el romano primitivo y únicamente la mano de obra es diferente; pero esta mano de obra quizás sea tan hispánica como la que utilizaron los romanos, los modos manuales de construir habrán cambiado muy poco, y además los materiales son los mismos o de la misma procedencia, por lo cual el puente sigue siendo esencialmente romano.

Variación importante supone el cambio de diseño en cimentaciones, pilas o arcos, como cuando so pasa del medio punto a la ojiva, o cuando se cambian los tajamares ampliándolos con la idea de cortar mejor las aguas; casos que se dan en nuestro puente. 
No cabe la menor duda de que si todos los arcos hubieran pasado de medio punto a ojiva tendríamos un puente ojival, es decir no romano, aunque se hubiesen usado los mismos sillares. En cambio, la conclusión no sería tan clara si la variación se redujera a los tajamares, ya que en general éstos recrecen a los antiguos y además en la mayor parte de los casos es una falsa mejora, pues el problema de atacar a la corriente no consiste en presentarles frentes desmesurados que por otro lado, con nueva cimentación sobre un terreno removido, en el mejor de los casos llevan la remoción unos metros aguas arriba, donde generalmente la cimentación deficiente y el gran peso del tajamar da lugar a un despegue de éste, separándose de la pila un trozo de fábrica descomunal con todas las condiciones de inestabilidad en proceso aumentativo. Además de variación accidental, es en la mayor parte de los casos un empeoramiento de las condiciones del puente. Sin más disquisiciones aparece el arco como una parte esencial del puente, mientras que los tajamares son secundarios y en el caso de adición verdaderamente yuxtapues. tas e innecesarias, visto el problema desde el momento actual. En nuestros puentes no es la importancia de los tajamares lo que se pide a una pila, sino precisamente su insignificancia, lo cual se consigue con su reducción a lo estrictamente estructural y su amoldamiento sencillo a las condiciones hidrodinámicas.

Por consiguiente, como norma general para la inclusión de los puentes en una determinada época, los consideraremos romanos en cuanto la variación de su estructura no haya afectado de un modo total a su silueta vanos y macizos, silueta que en definitiva se debe a los arcos. Por consiguiente, si éstos en su mayoría siguen de medio punto, como es el caso del nuestro, lo consideraremos entre los romanos, aunque la parte transformada, es decir los arcos ojivales, y en todos los casos los tajamares ampliados, los estudiaremos particularmente con los puentes de la época que les corresponde.

\section{descripción de lo romano}

El puente de Córdoba consta actualmente de 16 vanos, habiendo desaparecido uno, que era el extremo de la derecha, al realizar el encauzamiento de esta margen (lado de la ciudad) que redujo la longitud total proporcionando espacio para situar una vía marginal a lo largo del río por fuera de las murallas del recinto primitivo. Para hacer un recuento morfológico de los arcos los ordenaremos desde la orilla derecha a la izquierda, advirtiendo que su numeración disminuye en una unidad con respecto a los del puente primitivo:

1 arco rebajado oblicuo estribado en la muralla que oculta la pila;

2 y 3 arcos ojivales con pilas muy anchas reforzadas con tajamares muy desarrollados;

4 arco de medio punto más bajo que los anteriores y con pilas muy desarrolladas, de las más importantes del conjunto;

5 y 6 otros dos arcos ojivales con pilas también importantes;

7 arco de medio punto sin archivolta con clave hasta imposta superior;

8 y 9 medios puntos normales con pilas algo ampliadas, pero con tajamares menos desarrollados prolongados en pilastrillas;

10 y 11 medios puntos normales, así como sus pilas, que llevan pilastrillas cilíndricas;

12 y 13 medios puntos normales con pilas ensanchadas y tajamares importantes con pilastrillas;

14 arcos sin archivolta y pilares análogos a los anteriores;

15 arco normal con pilas algo ensanchadas y contrafuertes más acusados;

16 arco especial desarrollando sus bóvedas en tres alineaciones, pues atraviesa la zona en ensanchamiento para dejar en medio de la calzada el castillo de La Calahorra.

Tiene este puente tres alineaciones de $104,55 \mathrm{~m}, 107,30 \mathrm{~m}$ y $62,30 \mathrm{~m}$. 
Las luces de los arcos son $12,82 \mathrm{~m}, 9,48 \mathrm{~m}, 9,75 \mathrm{~m}, 10,31 \mathrm{~m}, 10,49 \mathrm{~m}, 10,78 \mathrm{~m}$, $11,12 \mathrm{~m}, 11,88 \mathrm{~m}, 11,88 \mathrm{~m}, 11,98 \mathrm{~m}, 10,21 \mathrm{~m}, 10,00 \mathrm{~m}, 10,03 \mathrm{~m}, 10,40 \mathrm{~m}, 10,40 \mathrm{me}-$ tros, $7,93 \mathrm{~m}$; el total desagüe es de $171,46 \mathrm{~m}$, según datos de Sáinz Gutiérrez.

Las boquillas de las bóvedas enrasan en plano de paramentos, pero quedan acusadas en todo su contorno superior por archivoltas toscas, a excepción de las 7,14 y 16 .

Los tajamares de pilas son normalmente triangulares simétricos en planta aguas arriba y redondeados $\mathrm{u}$ ojivales hacia aguas abajo, a excepción de uno de éstos casi cuadrado y otros de aquéllos con variantes en ojiva o asimétricos aguas arriba. Las pilas están ensanchadas, es decir, quedan emparedadas entro dos recrecimientos que se continúan por los tajamares de gran desarrollo tanto aguas arriba como aguas abajo. Creemos que ninguno de éstos es de los primitivos, que debieron ser en diedro muy recogido aguas arriba y semicilindricos en medio punto aguas abajo.

Una característica especial que aparece en las boquillas de los arcos es la archivolta que rebordea el trasdós, detalle que no se encuentra en ningún otro puente de los que hemos estudiado, ya que la disposición clásica es la continuidad plana de los paramentos. En puentes de Italia tenemos el de Augusto, en Rimini, y el de Narni, también de Augusto, con archivoltas análogas, y el del puente Elio, es decir de Elio Adriano, en Roma, que cruzaba el Tíber frente a su mausoleo, la Mole Adriana. En España tenemos arcos con archivolta en algunos monumentos triunfales: el arco de Cáparra, al que ya nos referimos en la Lusitania; el de Medinaceli. el de Bará y siendo detalle característico de todos los arcos y puertas monumentales en Italia y otras regiones del Imperio. Aparece ya en los arcos de puertas monumentales etruscas, siendo ejemplares la de Marte en Volterra y la de Perugia.

Creemos que estos arcos de boquilla con dovelas muy alargadas, en número de 40 a 50 y espesor de 1,35 a $1,50 \mathrm{~m}$, con sección trapecial, bien aparejados y labrados y rematados por archivolta sencilla, son los primitivos del puente, habiéndose llevado a cabc todos los reconstruidos con arreglo a dicho modelo. Algunos creen que es tipo musulmán por tener archivoltas, aunque más complicadas, los arcos de puertas de la mezquita. Pero aparte de las referencias directas que hemos dado a otros puentes de la época de Augusto, principalmente, es muy lógico suponer que algunos de los medios puntos son originales, ya que no iban a haberse destruido todos, salvo $\operatorname{los} 7$ y 14, que no tienen archivolta, y aquilatando más sólo dejamos el 14, ya que el 7 está en una zona donde seguramente se destruyeron todos los arcos, puesto que está en la mitad del puente más atacada por las aguas. Por lo tanto, creemos que de la otra mitad habrán subsistido algunos, y nos inclinamos a que todos, salvo los 10 y 11 de los cuales hay referencia documental de su destrucción y reconstrucción, nos dan lo auténticamente romano además del ejemplo que sirvió para reconstruir los demás medios puntos. Como actualmente los paramentos presentan un recubrimiento continuo sobre el que se ha remarcado el aparejo oculto no podemos aquilatar en los aparejos, pero en las fotos anteriores al revoco se aprecia que los últimos arcos junto a La Calahorra (tres o cuatro al menos) tienen muchas probabilidades de ser auténticos.

En cuanto a los tajamares, ya hemos indicado nuestra opinión de ser posteriores, reformas medievales avanzadas o de Edad Moderna aprisionando dentro los primitivos. Las fábricas de tímpanos tienen soluciones de continuidad correspondientes a las reconstrucciones de arcos, y reparaciones locales de arreglos de la propia fábrica, pues la piedra es poco consistente.

En cuanto a la cimentación, debe persistir la romana rehecho el zampeado general en bastantes zonas y desaparecido en las centrales de los vanos que llevan el peso de las avenidas. 


\section{puente de Alcantarilla}

Está sobre el arroyo Salado de Porcuna, cerca de la actual carretera de Sevilla a Cádiz, y debió pertenecer a la vía romana que unió Hispalis y Gades. También queda cerca de la estación-apeadero de la línea férrea que une ambas ciudades, y que lleva el nombre de La Alcantarilla que le dio precisamente el puente.

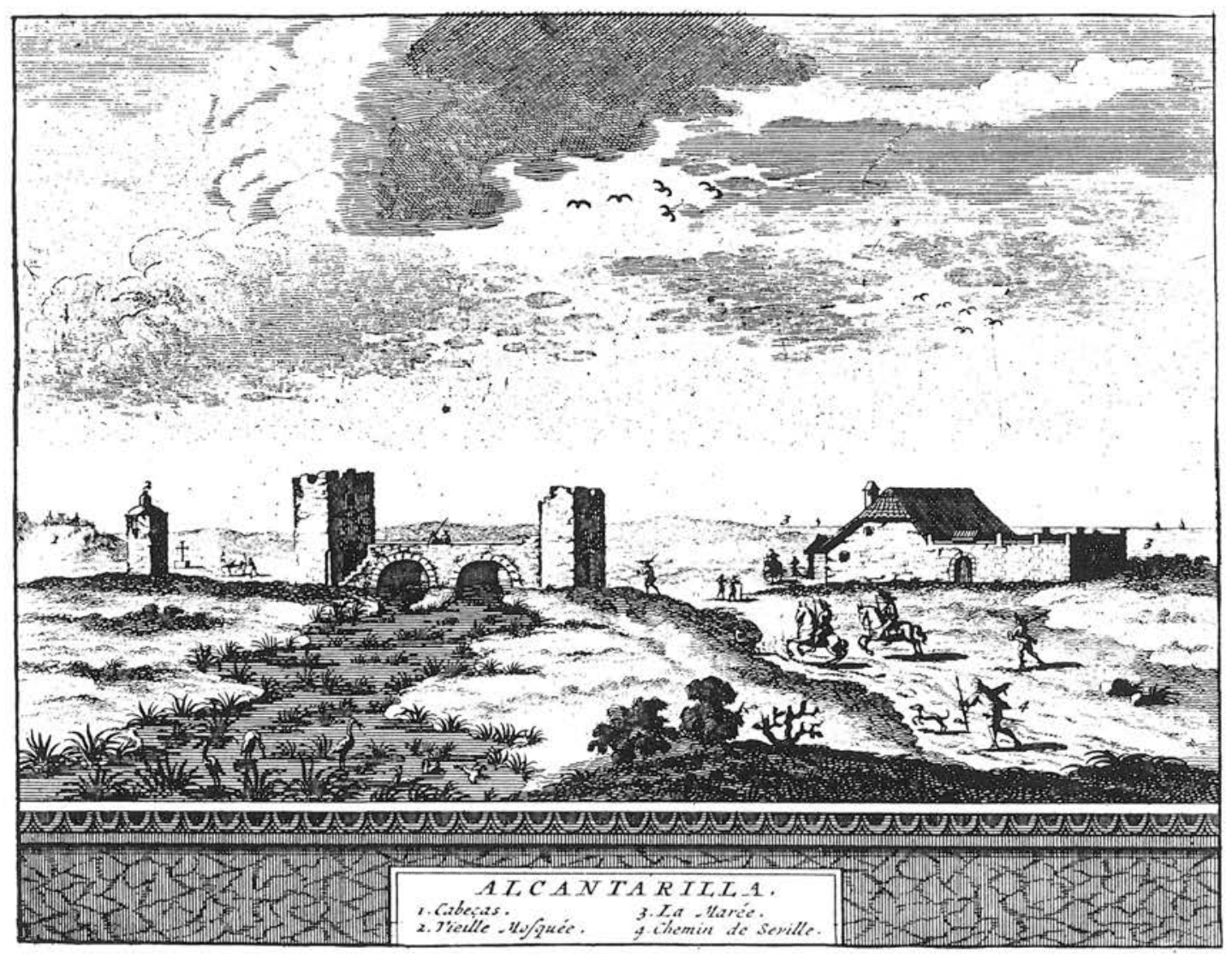

[47] Grabado de «La Galerie Agreable du Monde» (1720).

En una de las reformas de la carretera, que se había implantado sobre la vía romana cumpliendo el mismo objetivo, quedó fuera de servicio, pero después de cierto tiempo volvió a utilizarse incorporándolo a la nueva carretera desde la estación de La Alcantarilla a Utrera y entonces se realizó una importante reparación en el puente para acomodarle al nuevo tráfico. 
Vista desde aguas abajo.

Vista desde aguas arriba.

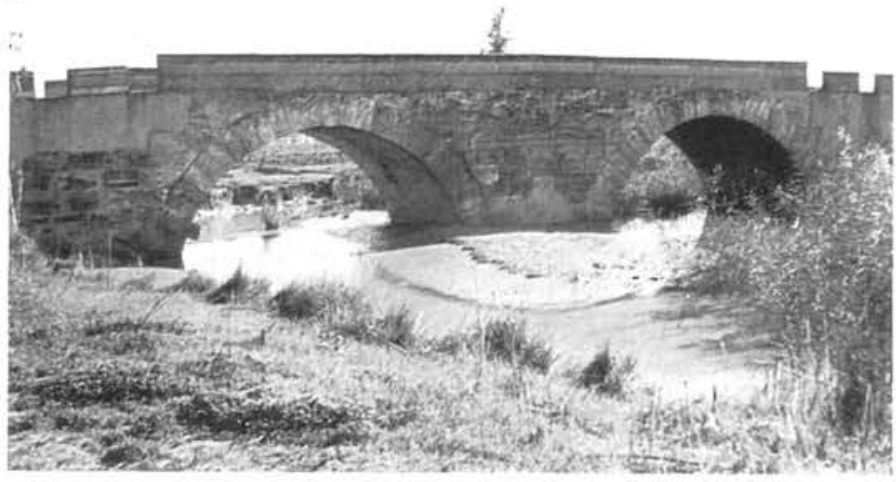

Foto actual
Consta de dos arcos con lu ces de 5,40 y $5,70, \mathrm{~m}$, separados por pila intermedia de gran anchura, que en realidad es relle. no de tímpanos entre las boquillas y que antes de la reforma aludida quedaba perforada por un hueco rectangular centrado, análogo a los arquillos de aligeramiento de tímpanos que hemos considerado típicos de los puentes romanos de época republicana. Sin embargo, queda otro hueco análogo en el estribo derecho. Debió tener rasante horizontal.

Los alzados no pueden ser más simples, los paramentos son planos únicos desde extremidad a extremidad de la obra de fábrica no habiendo resalto en boquillas ni en estribos, no pudiendo decirse nada respecto a la cornisa, pues la coronación es de época muy posterior a la romana. Para simplificar más la reforma última hizo desaparecer los huecos intermedios. Sin em bargo, quedan en la pila restos de los recuadros que sobre di cho hueco existian en los dos paramentos del macizo interme dio, e incluso una parte de la cornisa que lo delimitaba en el paramento de aguas abajo. Es tos recuadros tenían inscripciones hoy desaparecidas, pero con restos apenas legibles antes de la reparación, de los que según Gómez Moreno se deducían dos palabras "Augustus pontem" en la línea superior que parecen indicar la datación del puente. En la segunda línea se leía LPSR y TAUC, y en la tercera VIOCOS, siendo muy dudosa la primera letra de esta última que podría haber sido también M.

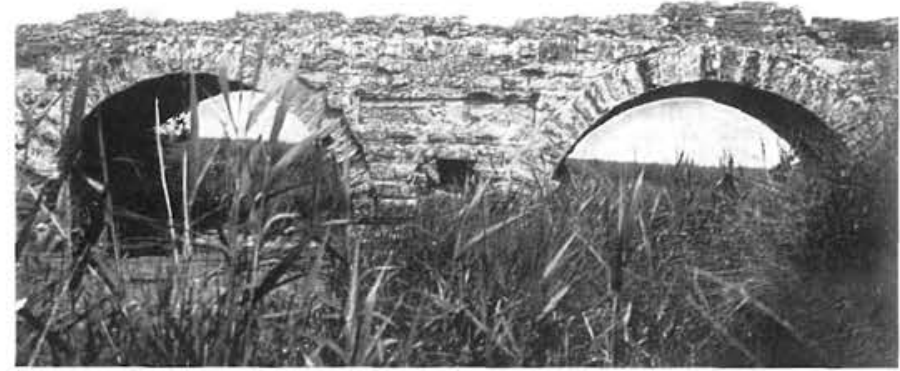

Foto antigua.

Foto actual.

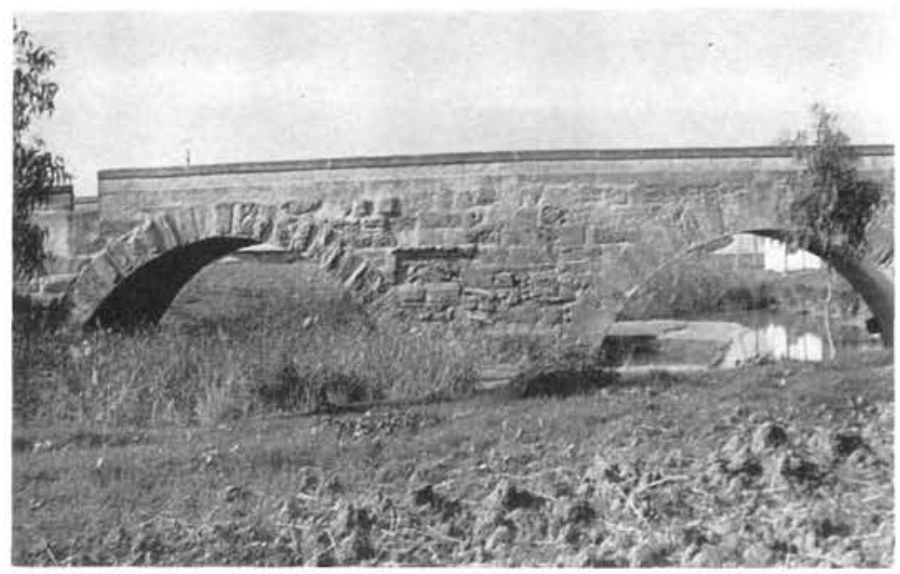

Foto antigua.

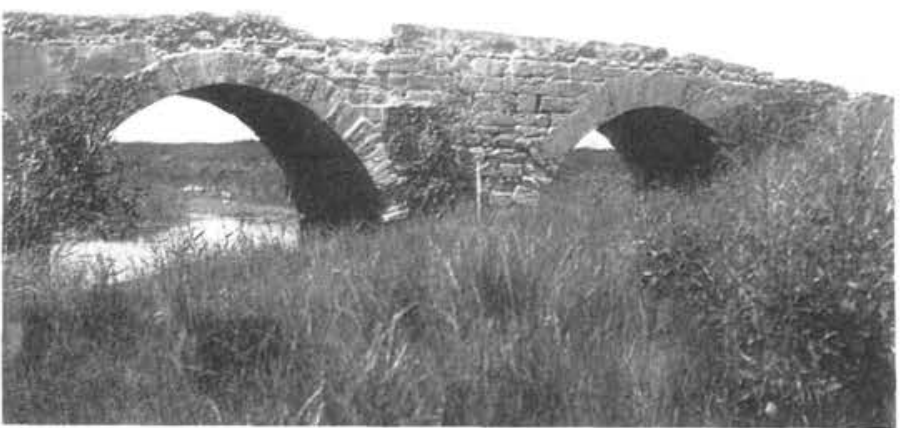



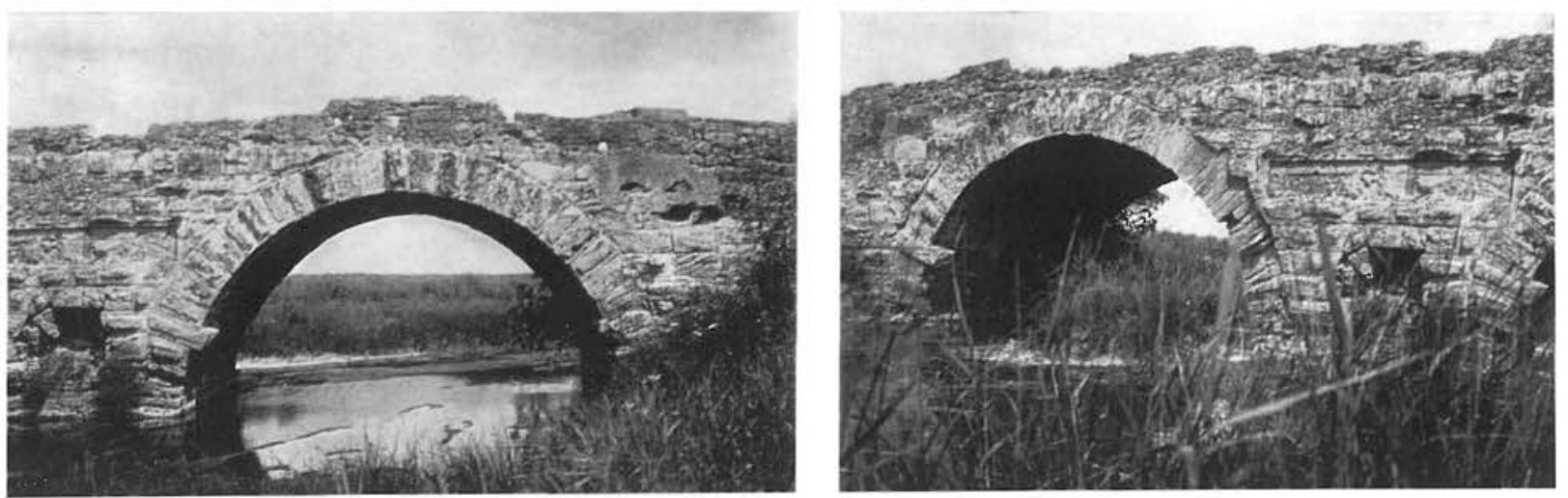

Las fábricas primitivas son de sillería poco cuidada con terminación superficial a lo rústico según Gómez Moreno. En los sillares auténticos que se conservan y particularmente en las dovelas, pues en gran parte se han sustituido o reparado, tenemos la labra tipica de la época de Augusto con recercado completo a nivel exacto, dejando la zona interna de cada sillar o do. vela con desbaste premeditado de más o menos abultamiento, pero con espesor del recrecido muy uniforme. Otro detalle cu-
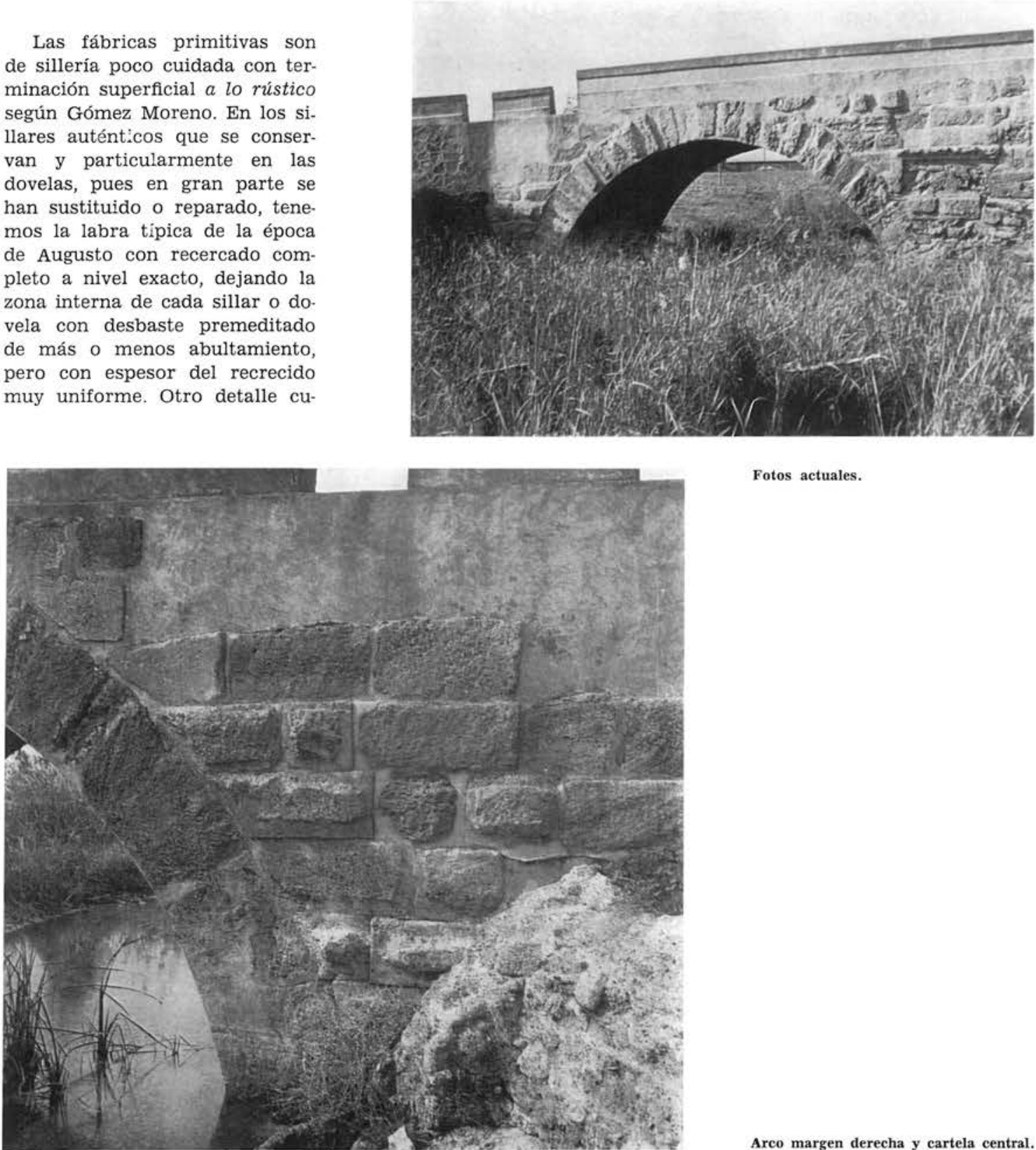

Fotos actuales. 


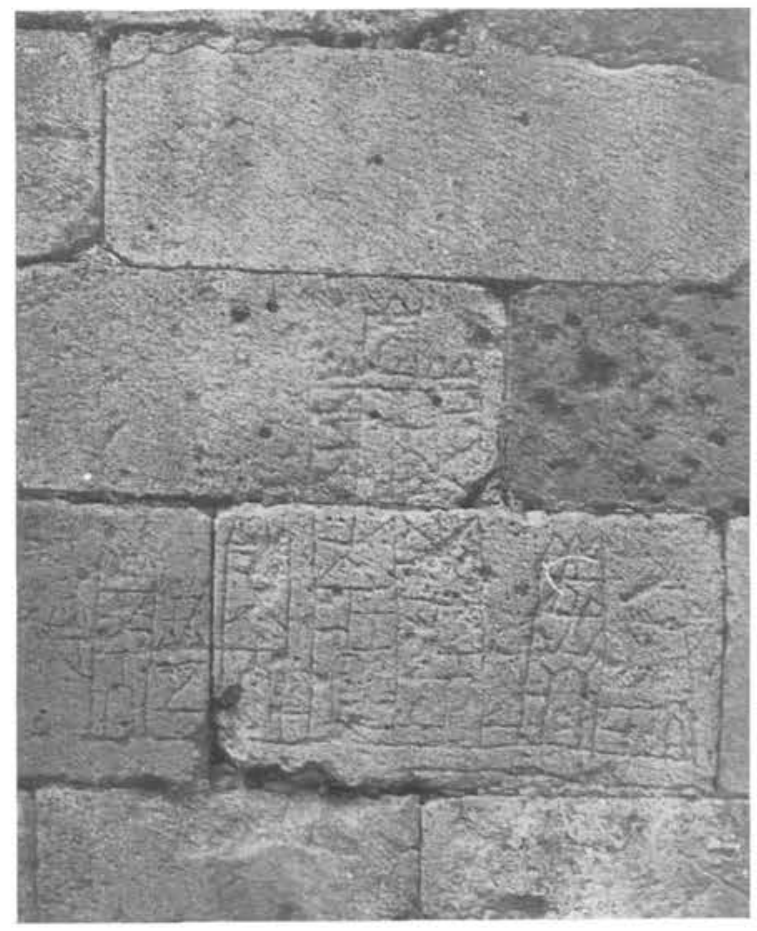

Dibujos incisos en sillares de aguas arriba. (Foto Gómez Moreno.) rioso muy típico de la época augustea es la prolongación de dos dovelas simétricas de las boquillas a la altura de riñones, que encontramos por ejemplo en Pont du Gard. Existen dovelas y sillares con terminación plana, pero se ve claramente que son de reformas posteriores modificadas por sustitución o relabra.

La inscripción y las fábricas casi aseguran que es un puente de Augusto. Tenía torres defensivas a ambos lados que se derrumbaron a principios de siglo. Las cita C. Espinosa en 1878. Quedan ruinas de una fortaleza medieval edificada con sillares romanos, que defendía la entrada del puente, y que aparece en el grabado que se reproduce.

Debemos al ilustre maestro D. Manuel Gómez Moreno las fotografías de la obra antes de la reforma, que permiten conservar detalle del hueco desaparecido con la reforma, y las interpretaciones de las inscripciones hoy más deterioradas que entonces. Sirva esta referencia de homenaje a su memoria.

Es monumento histórico figurando con el número 826 en el Catálogo de Monumentos Nacionales.

Fortaleza medieval que defendía el paso. (Foto actual.)

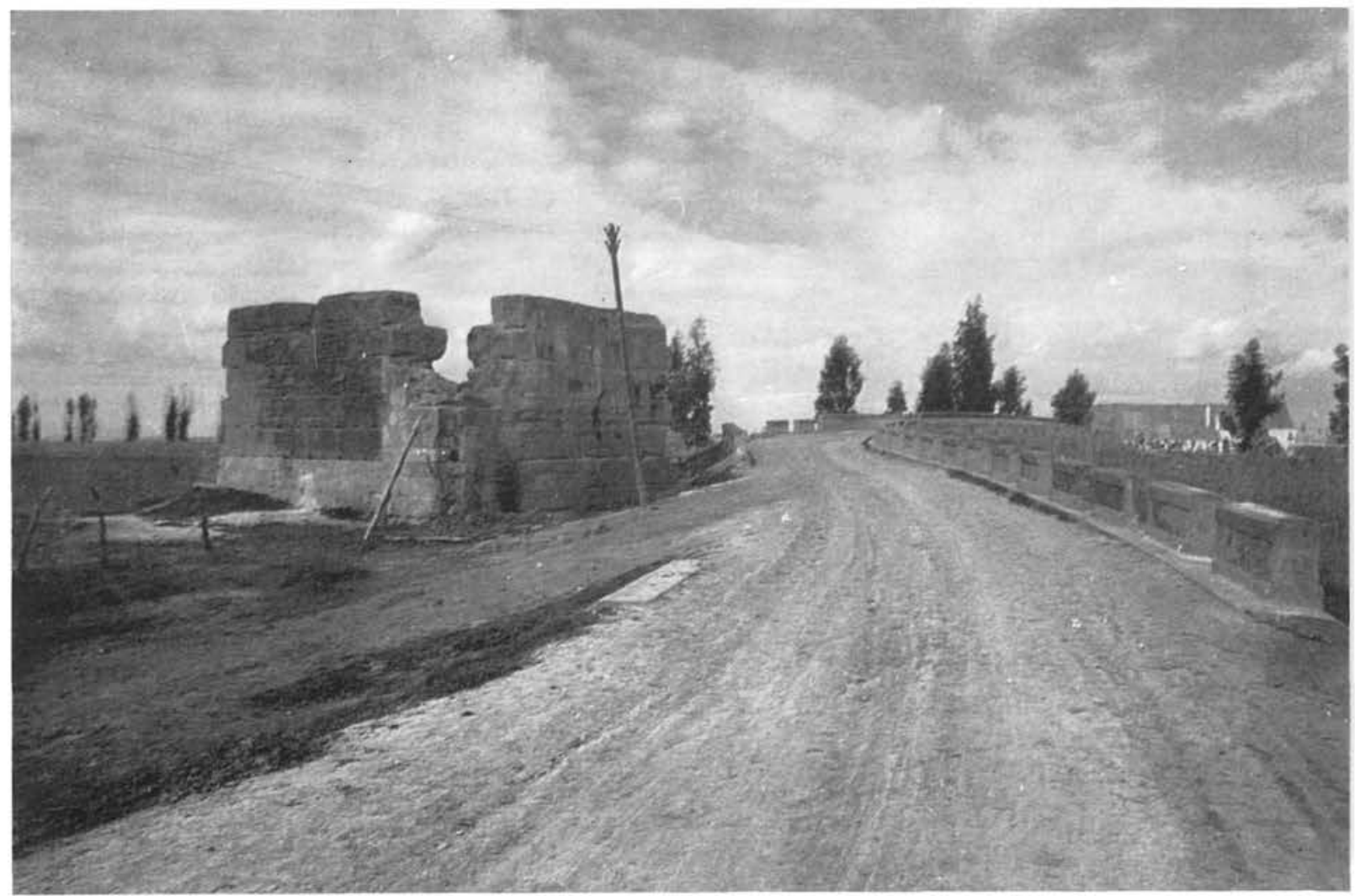




\section{puente de Rabanales}

Está situado a unos $3 \mathrm{~km}$ de Córdoba, junto a la carretera de Andalucía, a la cual servía hasta el año 1928, cuando entre las mejoras llevadas a cabo en dicha carretera por el Circuito Nacional de Firmes Especiales, se hizo una modificación de trazado para evitar el pequeño rodeo que este puente suponía.

Tiene cinco arcos de luces que deberían ser iguales a 10 pies, aunque probablemente por construcción son ligeramente diferentes. Los arranques de los arcos están al nivel del terreno, y aunque algunos dan menos del medio punto será debido a la elevación del terreno por sedimentación en los años transcurridos desde su construcción.

Es todo de "opus quadrata", a excepción del pretil, que es obra típica del siglo XVIII, de simples dados de piedra rematados en baquetón. El aparejo de los sillares y dovelas es muy cuidado, aunque la superficie de las mismas se ha deteriorado por meteorización. El juego de paramentos no es característico de los puentes romanos, pues se escalonan tres planos: uno, el más rehundido, correspondiente a boquillas y enjutas; el segundo corresponde a pilastras en los macizos dejando libres estrictamente las boquillas; y el tercero en coronación tangente a claves a todo lo largo de la obra entre estribos, los cuales definen un cuarto plano con ligero avance. Por último, una segunda cornisa, ésta ya corriendo de extremidad a extremidad de la obra de fábrica, sobresale y sostiene el pretil.

Es muy posible que esta última cornisa sea como el pretil del siglo XVIII. Los arcos tienen 25 dovelas perfectamente trapeciales. Las enjutas llevan cuatro o cinco hiladas de distinta altura y las

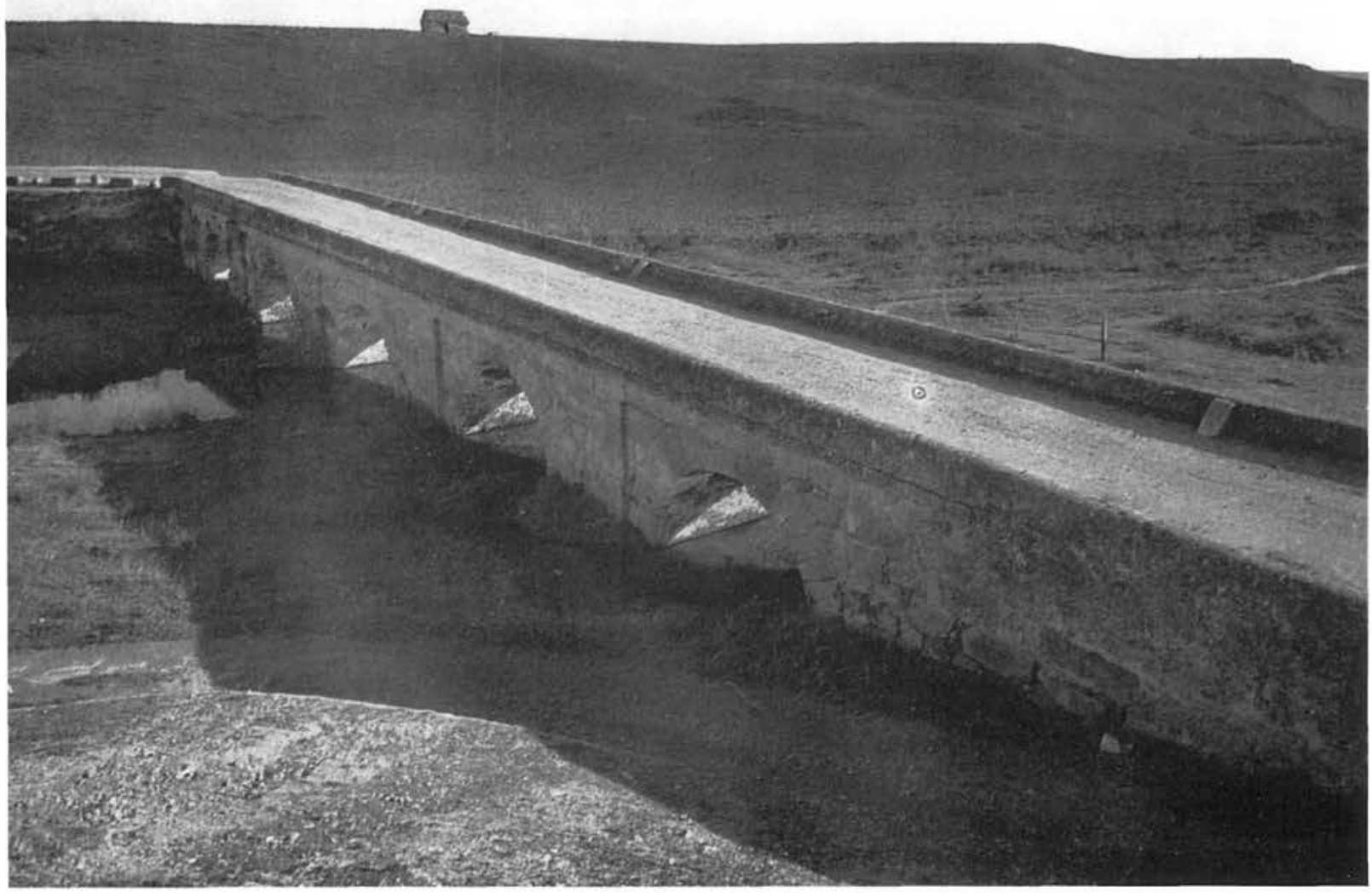

Vista general desde aguas abajo. 

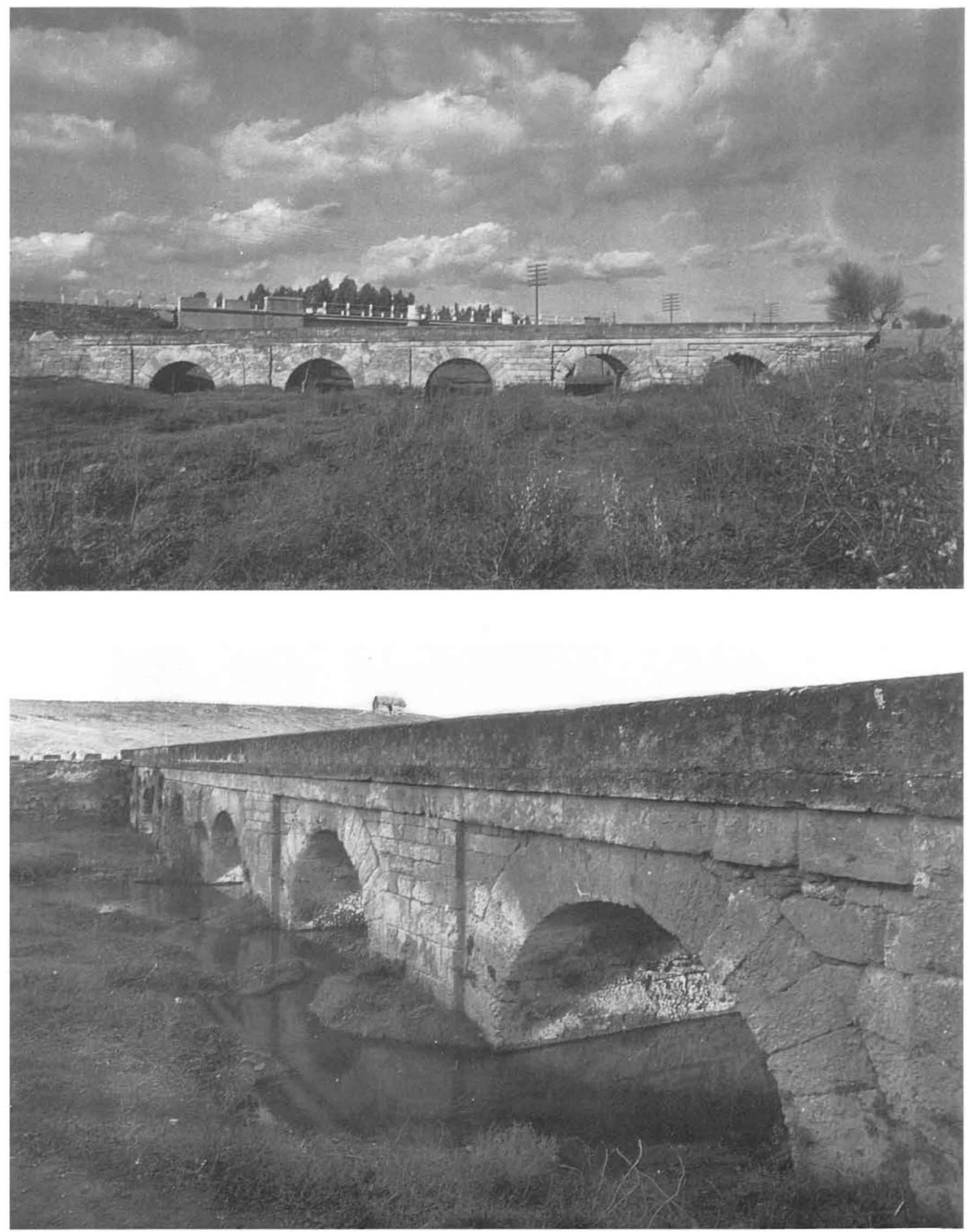

Vistas generales desde aguas arriba $\mathbf{y}$ desde aguas abajo. 


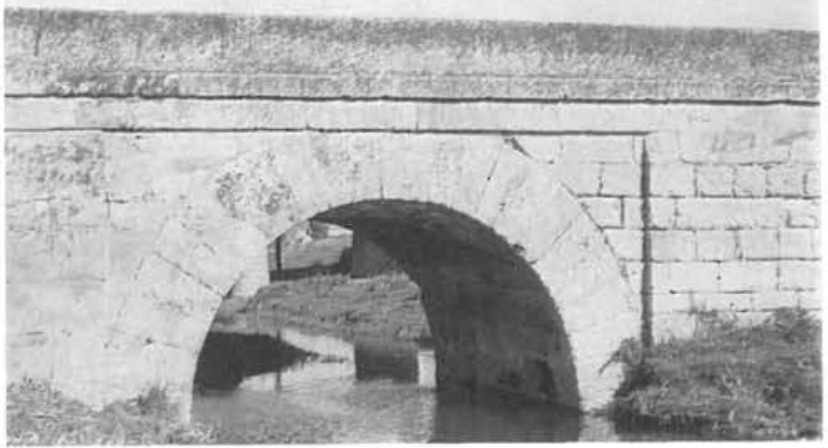

pilastras siete $u$ ocho con gran irregularidad en las dimensiones.

La fábrica se conserva bastante bien, exceptuando las boquillas de aguas arriba de dos de los arcos extremos y los tímpanos intermedios.

También la sillería de las bóvedas correspondientes están restauradas a trechos con fábrica de ladrillo. Al construirse la variante de carretera con un nuevo puente, ha dejado de prestar servicio.

Detalles del último arco de margen derecha.

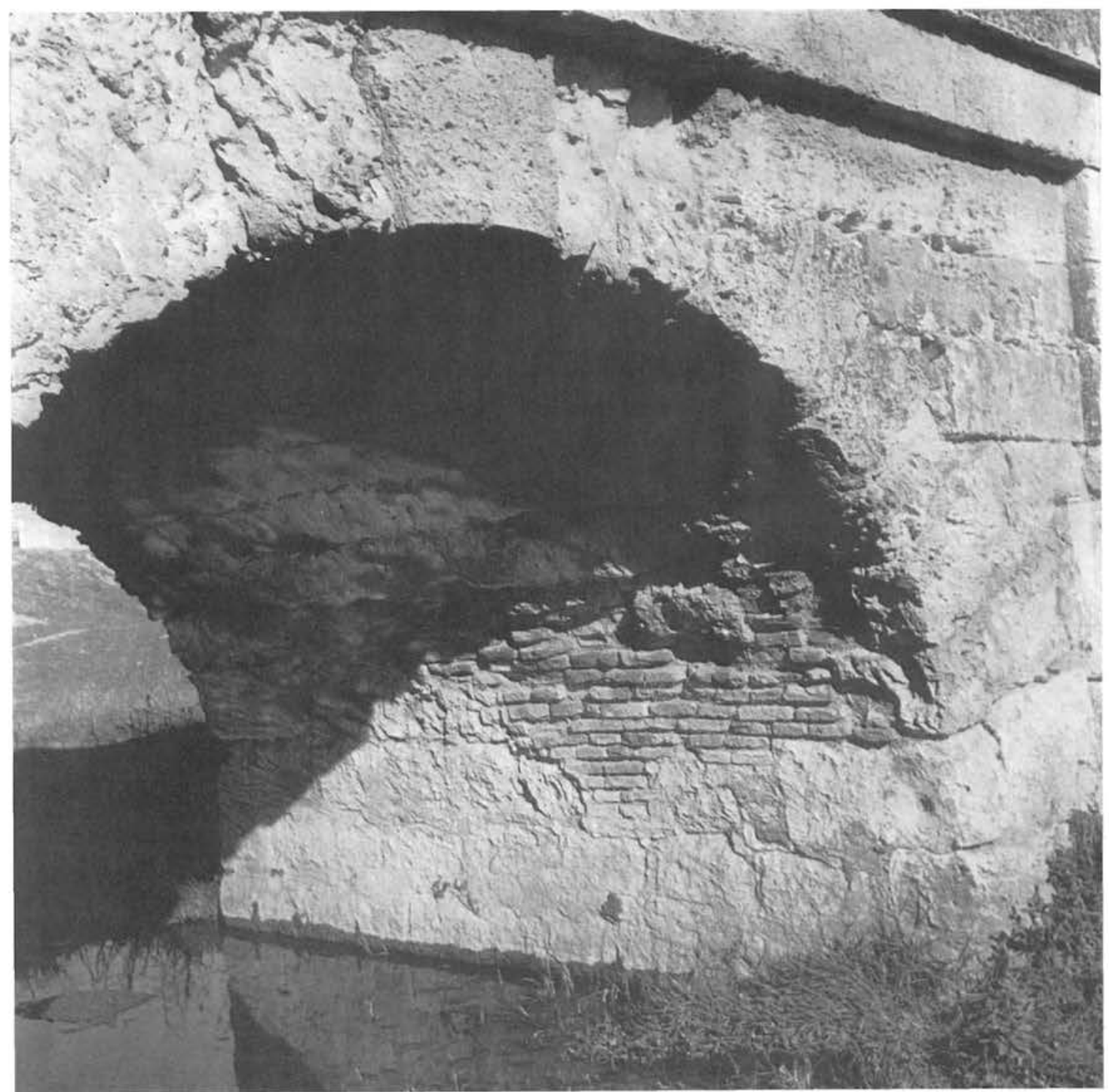




\section{puentes de Ronda}

Ronda, que se denominó Arunda en la época romana, aprovecha la situación estratégica que supone la diferencia de nivel de cerca de $200 \mathrm{~m}$, producidos por un corte casi vertical, corte que a su vez está dividido en dos al haberse formado la hoz correspondiente al cauce de un río (el Guadalhorce actual) que antes se despeñaba en el escalón de dicho tajo.

Se instaló utilizando los dos accidentes naturales como escarpes defensivos inexpugnables, constituyéndose además en atalaya avizorando el paisaje. Pero estas ventajas tornáronse dificultades para la incorporación a una vida de relación que precisaba mejor enlace, para lo cual el foso que constituía la hoz del río se podía salvar mediante puente en la zona inicial donde el corte era menos profundo y a la vez de menor anchura. Existen tres puentes en Ronda que corresponden a tres etapas en la solución de este problema, de los cuales el puente de El Tajo, por antonomasia, es el del siglo XVIII, que se ha encajado sobre lo que pudiéramos llamar desembocadura de la hoz en el llano. Los otros dos se suceden próximos en la zona alta y con una diferencia de cota de unos $30 \mathrm{~m}$, aunque con envergadura de obra análoga, pues aunque la anchura de la hoz va aumentando a medida que desciende, no ha sido mucha la ganancia en esta zona, y además en el de aguas arriba el arco está a estribos perdidos y en el otro los muros de acompanamiento penetran en el cauce reduciendo la luz del arco.

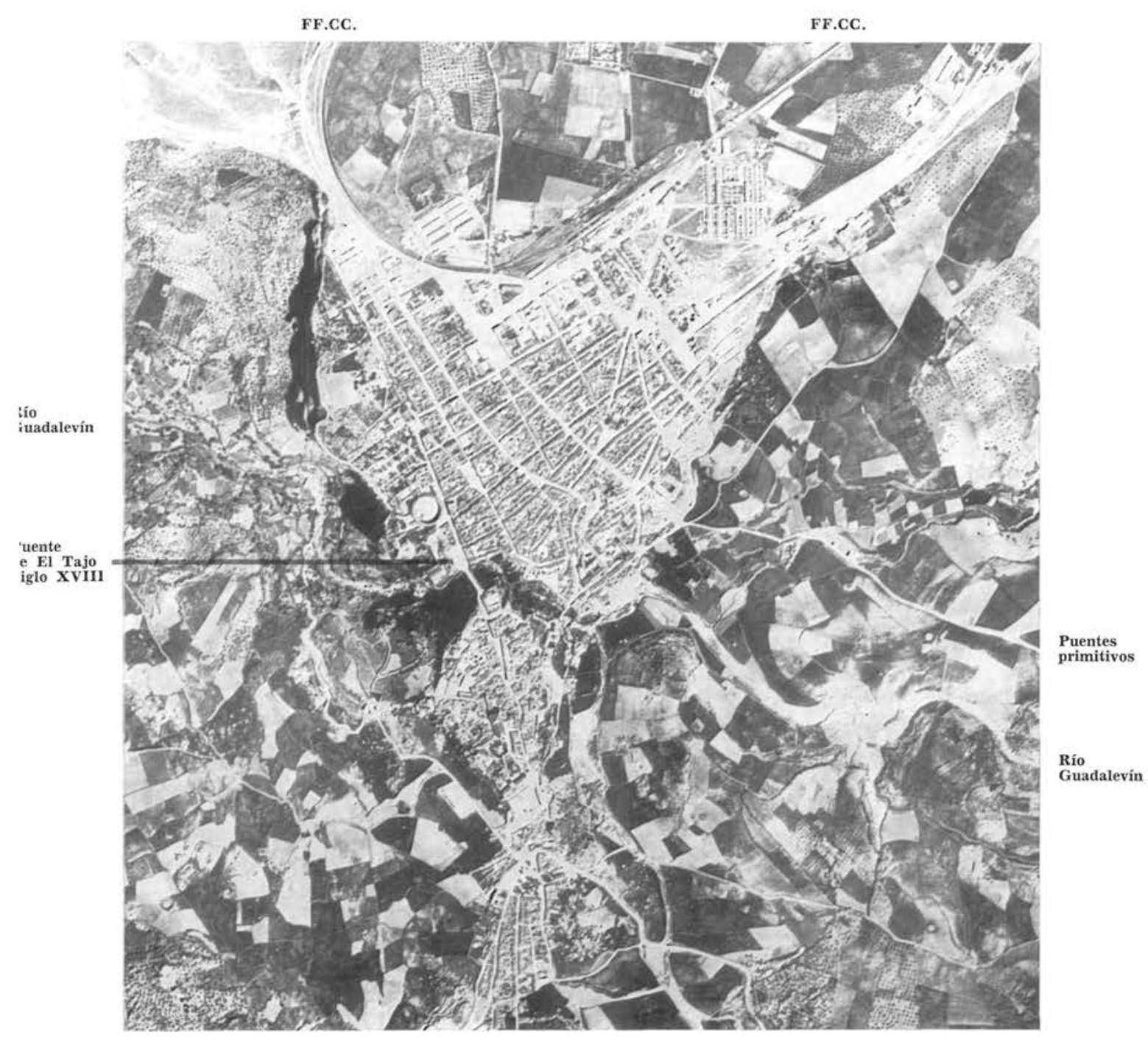

Plano aéreo de Ronda. 


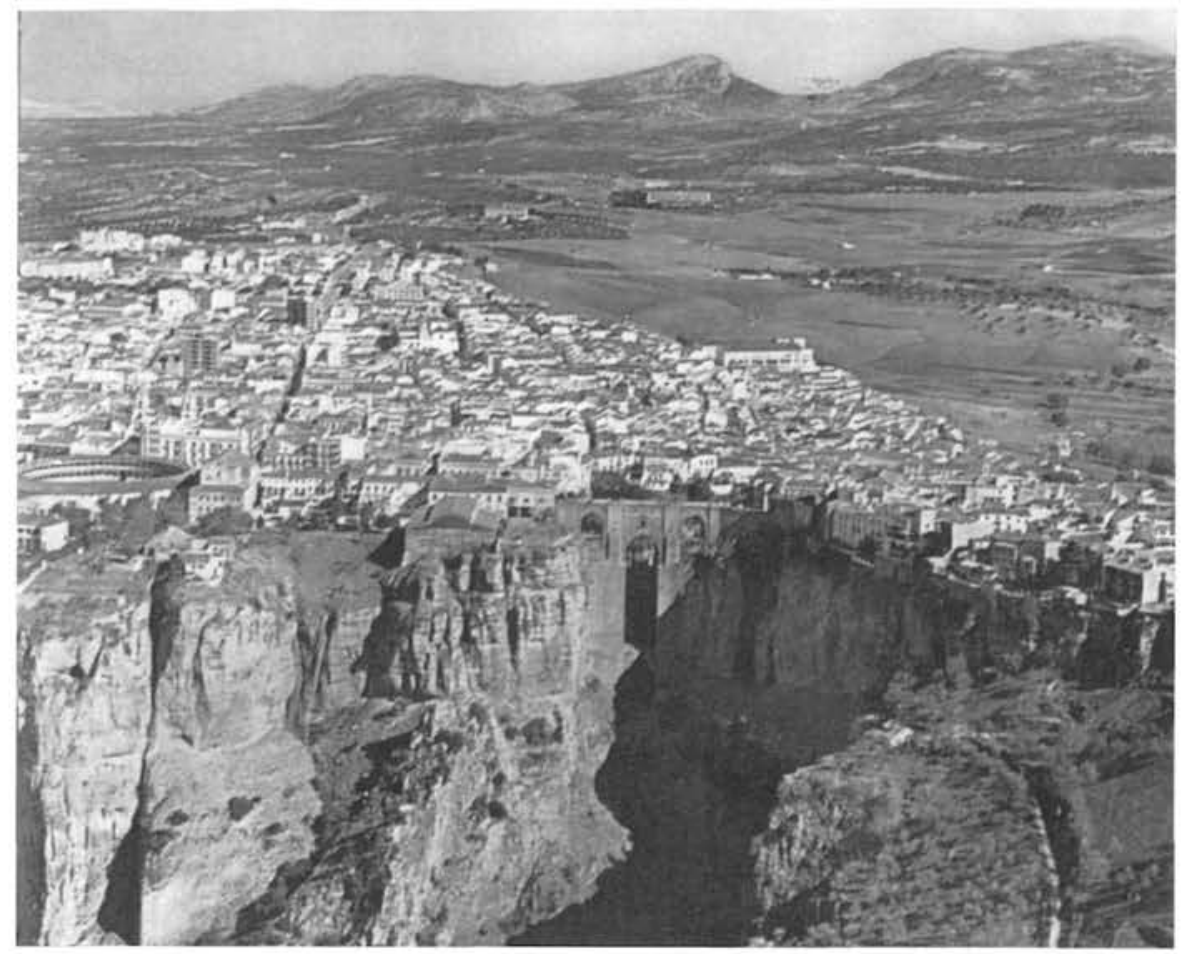

Vista frontal de EI Tajo de Ronda.

Rampas de bajada desde la zona alta del núcleo principal de la ciudad has

El puente principal es, naturalmente, el del XVIII, ya que apareció para unir los dos núcleos de la ciudad que habían ido desarrollándose hasta ocupar primero el islote derecho que es el de la ciudad antigua y después la zona del otro lado del río donde no existe obstáculo alguno para la expansión urbana, que sólo queda limitada por un lado que es el borde del tajo y ofrece además una topografía adecuada para el desarrollo de calles y plazas. Este puente queda para el artículo correspondiente a la época de Carlos III y ahora sólo nos vamos a ocupar de los otros dos.

Fstos dos puentes que están incorporados al mismo paisaje, apareciendo en las fotografías clásicas con un eje común, se denominan árabe y romano sin ninguna base documental ni estilística, ya que en el inferior el estilo es atípico, y el superior con sus dos roscas de sillareio casi en lajas puede ser romano o medieval y en este se-

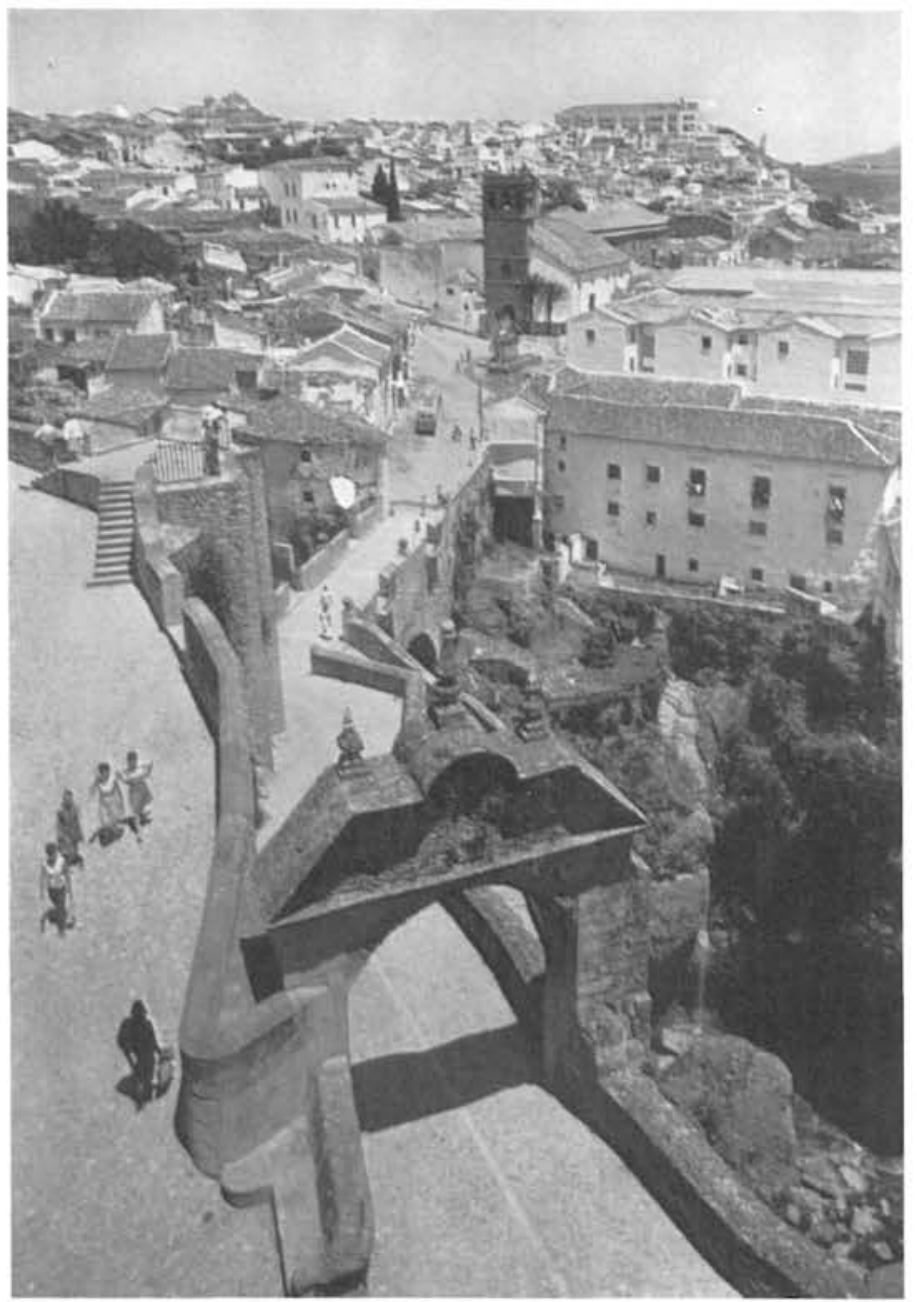


El puente principal de 1776 , reinando Carlos in.

Los puentes más antiguos tal como aparecían antes de la última reforma.

gundo caso árabe o del siglo $\mathrm{XV}$, es decir cuando el primer desarrollo de Ronda cristiana.

E1 puente inferior se introduce en el cauce con muros desde ambas márgenes hasta delimitar una luz de $6,30 \mathrm{~m}$ mediante arco que en el arranque izquierdo se apareja todo él con dovelas bastas radiales, ordenación que luego se continúa en sillares horizontales del mismo tipo, resultando las aristas del muro de acompañamiento.

En el arranque derecho la fábri. ca de sillares bastos que delimita las aristas del muro se continúa en hiladas horizontales de lajas irregulares hasta riñones, donde empiezan las dovelas radiales dando un contorno de intradós más tosco que el del otro arranque.

Los tímpanos en el mismo plano que las boquillas se continúan delimitando el remate primitivo con mayor lomo de asno que el actual, pues se ve claramente en las fotografías antiguas el recrecimiento que ha allanado la plataforma. E1 pretil que se ajusta al plano único de paramentos no es el primitivo y ha debido reconstruirse en diversas épocas.

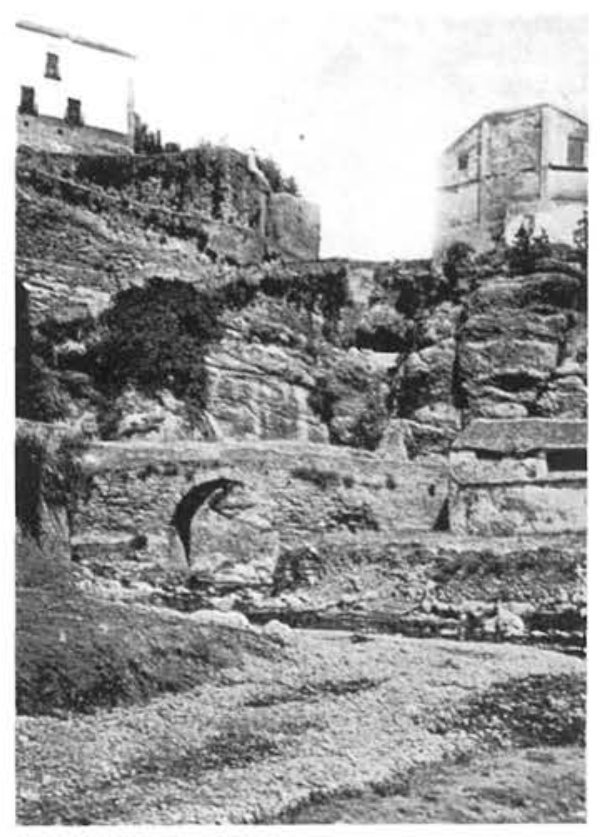
El puente de nivel inferior, aunque intermedio en el
río, de estilo atípico.
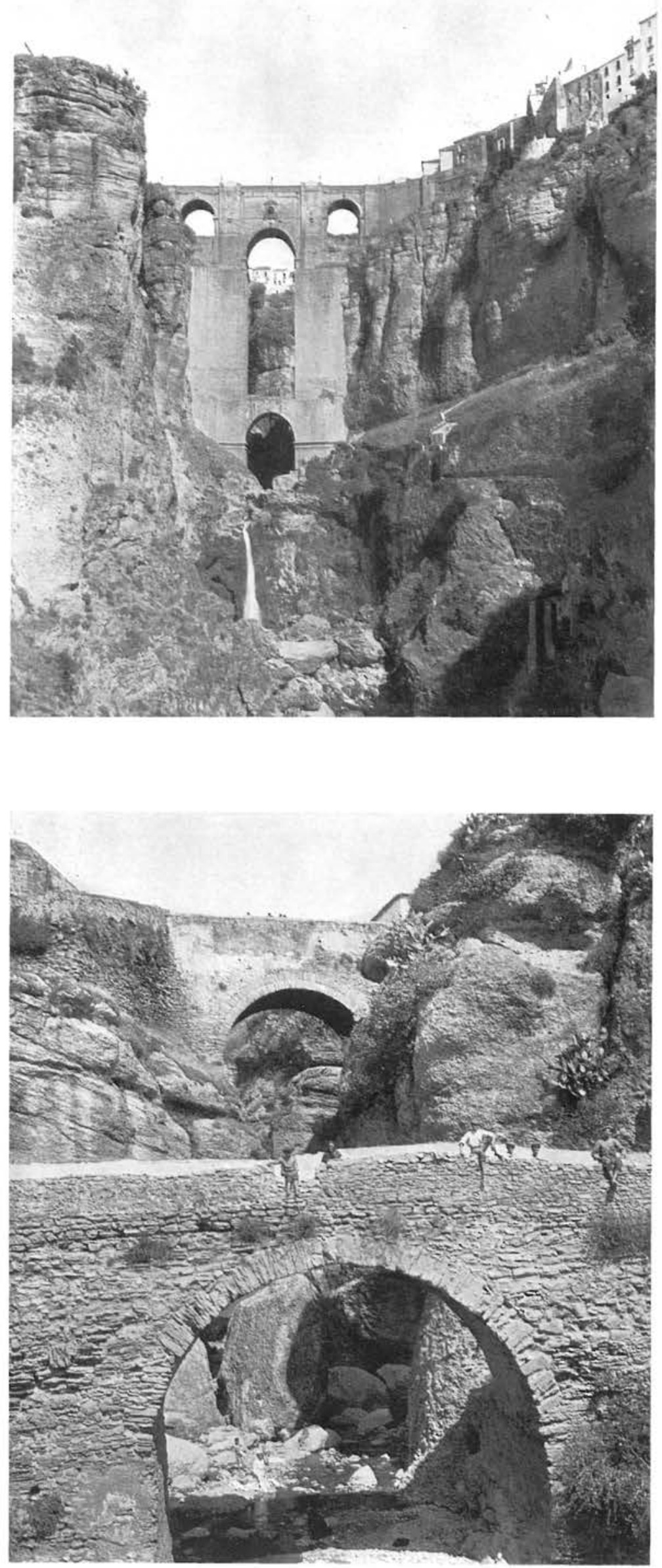


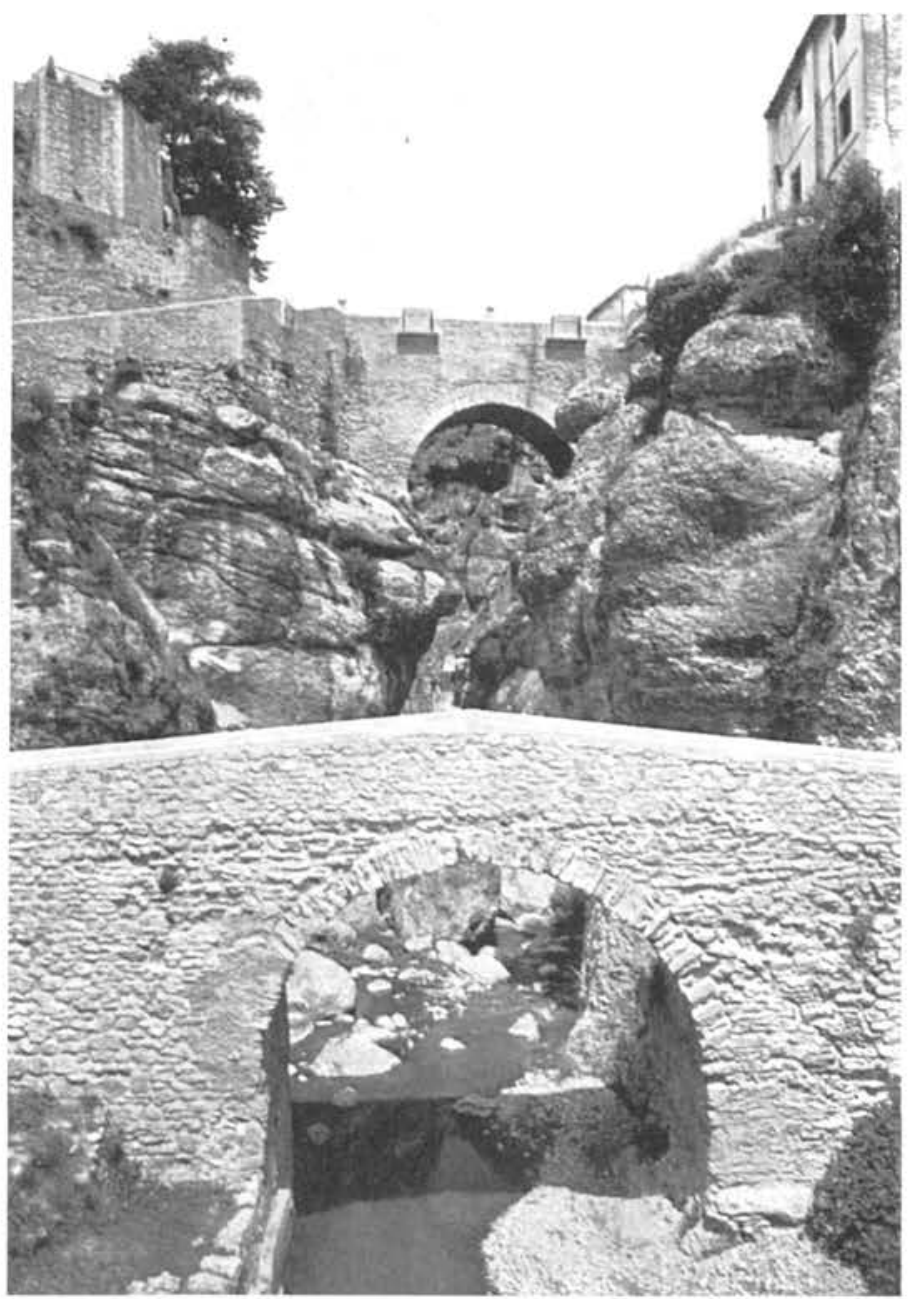

Los dos puentes antiguos en su estado actual.
El puente superior tiene una bóveda mejor encajada en diseño y construcción; arranca directamente desde la roca $\sin$ necesidad de estribación complementaria, por 10 cual en el arranque derecho parece que se continúa en más de medio punto dando la apariencia de un arco de herradura, aunque en el arranque izquierdo, por el contrario, el medio punto se prolonga en vertical. De las dos roscas que forman la boquilla sólo el desarrollo de la inferior corresponde a la descripción anterior, pues la segunda arranca por ambos lados a nivel de riñones.

En las fotos antiguas se aprecia claramente que las enjutas del arco se coronaban tangentes al trasdós de clave que deben ser el nivel natural de las márgenes, pero recrecimientos posteriores de los tímpanos han elevado notablemente el nivel de la plataforma. La última restauración después de nuestra guerra ha recortado dos huecos en el pretil, volando sendos balcones y suporponiéndole tres bolas distribuidas en centro y extremos.

Aunque en algunas referencias se dice que hay sillares romanos en la base del puente del XVIII, no es verdad y además no es lógico que los hubiera. Madoz lo da como romano, reedificado en tiempo de los árabes, pero no hay base material para ello.
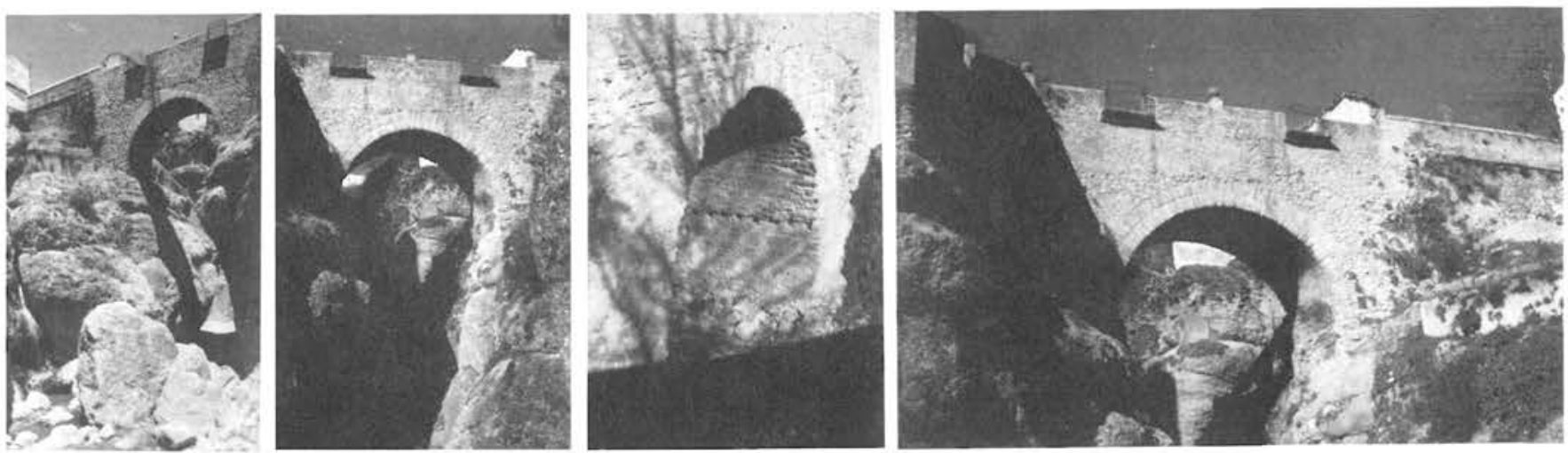

Distintos aspectos del puente, a nivel intermedio, romano o medieval. 


\section{puente de Alcalá de Guadaira}

Este puente sobre el río Guadaira que lo cruza al amparo de una elevada colina, situación estratégica que dio lugar a un castillo en época árabe para defensa permanente del paso y de la ciudad que se había asentado aprovechando la concentración de circulación que el puente supuso. Madoz lo califica de romano y resalta la importancia que tiene para la comunicación hacia el sur en invierno.

Es un magnífico puente con cinco arcos principales, todos de la misma luz y con sus claves a la misma altura y sendos arcos laterales en las márge nes de luz mucho más reducida (la mitad) y las claves mucho más bajas. Parece indudablemente romano por su apostura, la buena construcción y traza y según se deduce de referencias existía ya a la llegada de los árabes.

La clásica disposición de paramen tos lisos $\sin$ resalto de las boquillas, tajamares triangulares aguas arriba con cuerpos coronados a más altura que el arranque inadvertido de las bóvedas y cuerpos cilíndricos en los frentes de aguas abajo coronados, ahora sí, a nivel de arranques de arcos con sombreretes cónicos hasta coronación. Estos cuerpos cilíndricos han desaparecido bajo fábrica de refuerzo en contrafuertes escalonados de todo su diámetro, dejando sobresalir las puntas de sus afilados capirotes. La razón de esta reforma, que hay que situar en el siglo XVI (análoga con la del puente de San Martín, en Toledo) y en la socavación de cimientos y deterioro de las bases a consecuencia del mayor trabajo de la corriente en la zona central del río. También se han retocado las zapatas que sobresalen como basamentos y probablemente en épocas sucesivas. Algunas de las reparaciones deben corresponder a las que se atestiguan documentalmente en el Catálogo arqueológico y artístico de la provincia de Sevilla, datados en los años $1541,1617,1633,1672$ y 1717 , unos por el cabildo de Alcalá y otros por el de Sevilla, al que se recurre. Era muy importante a esta ciudad, pues Alcalá era uno de los pueblos abastecedores de la misma. La reparación de 1780 consta en una lápida existente en la cara de la huerta de La Tapada, sita en uno de los extremos del puente, fijando en 50.700 reales su coste.

En el siglo actual se hizo un ensanchamiento de la calzada por el desastroso procedimiento de volar aceras y sustituir el pretil por barandilla metálica.

Detalle de $\operatorname{arcos} \mathrm{y}$ tajamar a abajo.

Frente de aguas abajo.

Frente de aguas arriba.
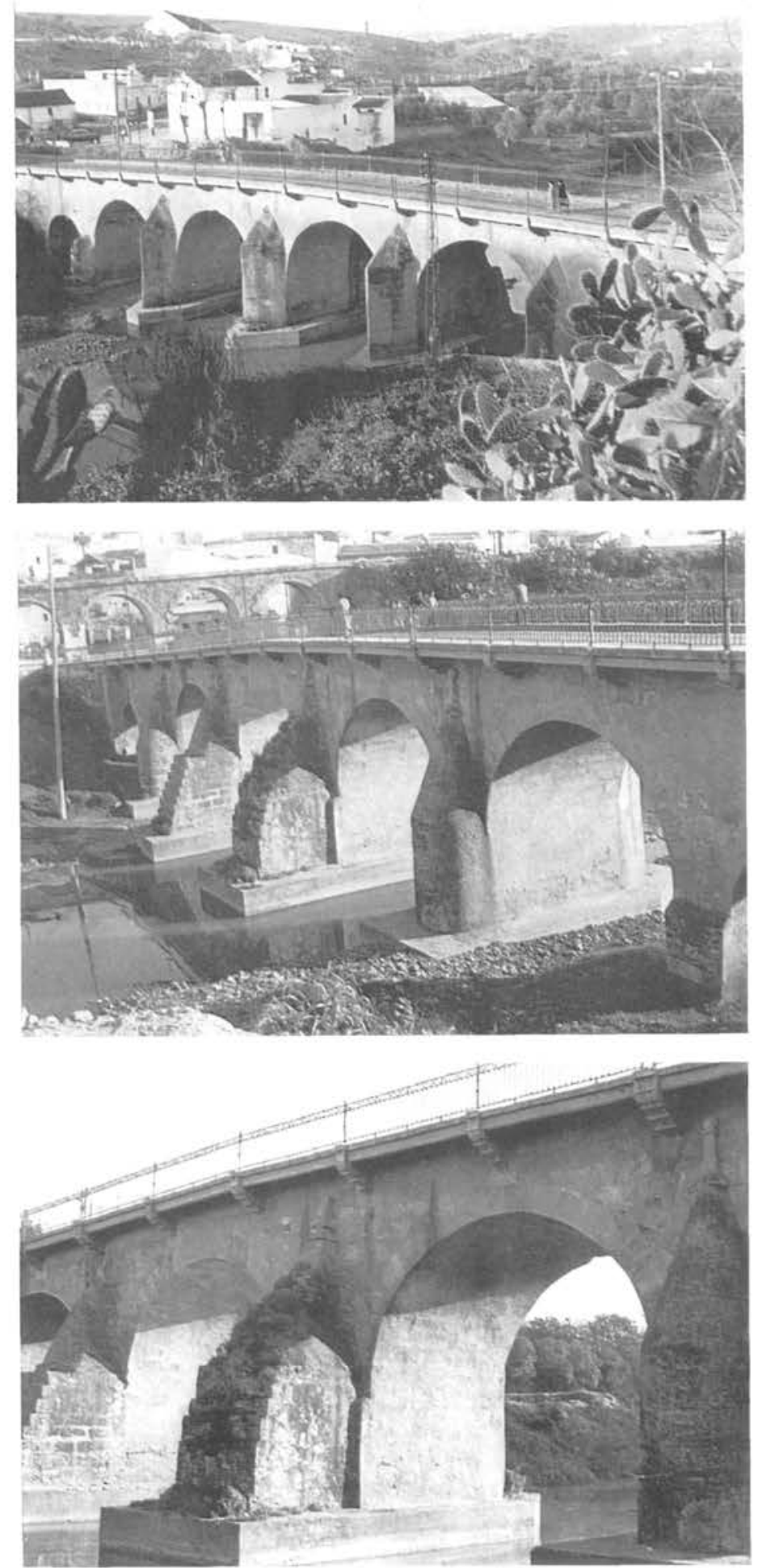


\section{fotoplano \\ Alcalá de Guadaira}

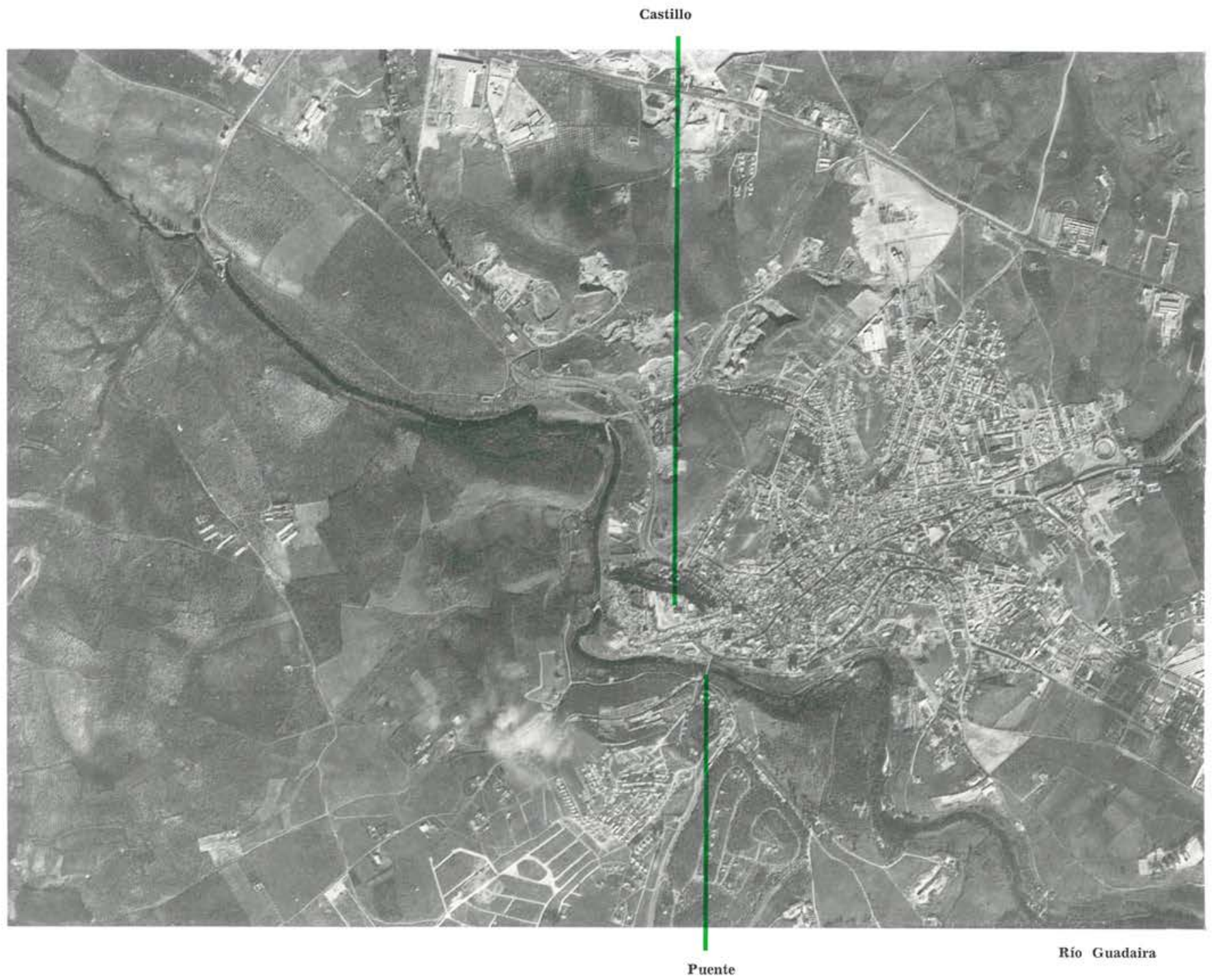




\section{puente de Niebla}

Este puente sobre el río Tinto en su estado actual es una mezcolanza de arcadas de medio punto, ojivales, o con arcos rebajados; las bóvedas son de sillería basta o de ladrillo y tiene rasante horizontal, pero la tuvo a dos vertientes antes de la última transformación, única conocida y documentada, que se realizó recientemente para ensanchar la calzada, volando las aceras mediante una cornisa con mensulones tribolados, de $1,30 \mathrm{~m}$ de avance, de hormigón armado, con lo cual se pudieron trasladar otro tanto los pretiles, quedando en vuelo los paseos. En esta transformación se enfoscaron además todos los paramentos viejos y nuevos (al recrecer los tímpanos) y la obra quedó verdaderamente enmascarada, con lo cual la confusión de épocas se hace más indescifrable. El proyecto de esta transformación era mucho más ambicioso, pues comprendía la construcción de torres a la entrada y salida del puente, torres que seguramente existieron pero de las que no se conserva referencia ni vestigio algunos.

Vista desde aguas arri. ba. Al fondo las
llas de Niebla.

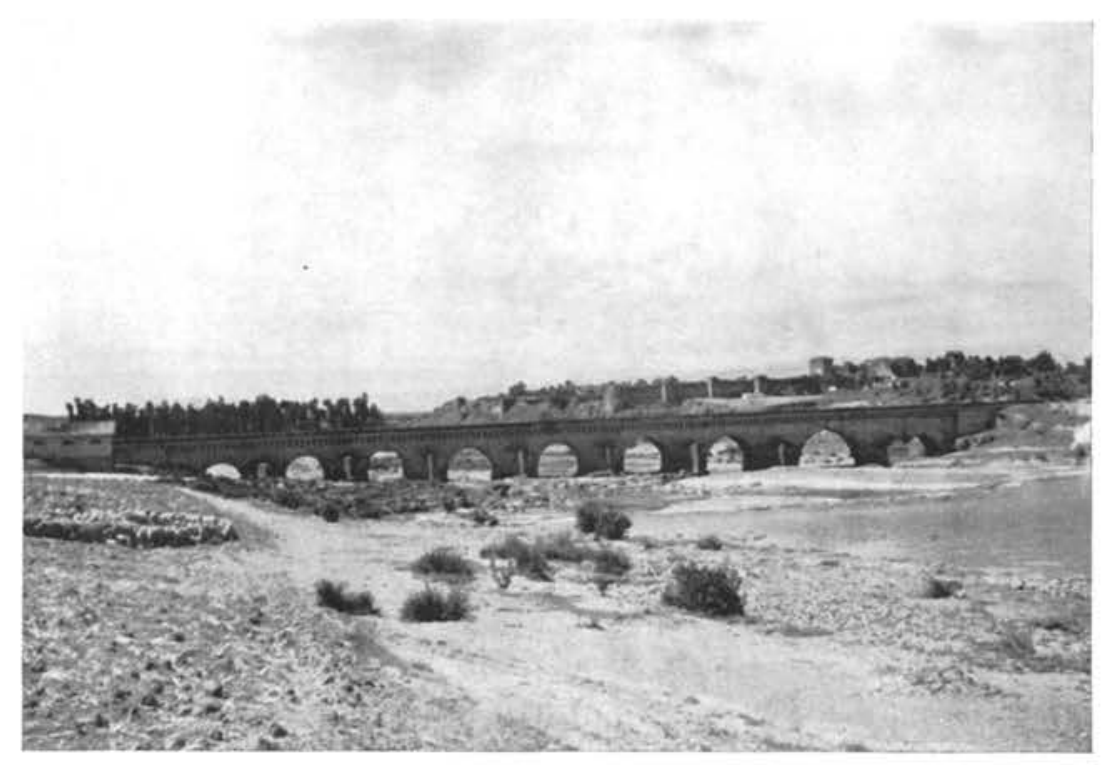

Con respecto a su ascendencia romana tenemos indicios bastante fehacientes, ya que las ojivas son de ladrillo y los medios puntos de sillería, lo cual todavía puede verse en los paramentos internos. Esto quiere decir que el puente tiene su origen antes de la época ojival, y como no puede ser románico, ya que la zona estaba bajo la dominación musulmana en la época correspondiente, no le queda más que ser romano.

Está en la carretera de Sevilla a Huelva, que en esa zona debe coincidir con la vía romana de Ostio Fluminis Anae a Emérita (Ayamonte-Mérida), ya que Onuba, que está reducida a Niebla, era la mansión cuarta de esta vía en el Itinerario de Antonino. Este puente servía al cambio de orilla, ya que luego la vía seguirá paralelamente al río huyendo de las zonas bajas inundadas por él en aguas altas. En el paso el camino se eleva instalándose en una meseta dominante que empieza siendo cabeza de puente defendida por una eminencia que primero castillo se transformará en ciudad amurallada, ya que va a quedar en una línea de tensión cuando el avance de la Reconquista. Al caer Niebla cercada por Alfonso X (1262) en un asedio dificultoso, pues los mu- 

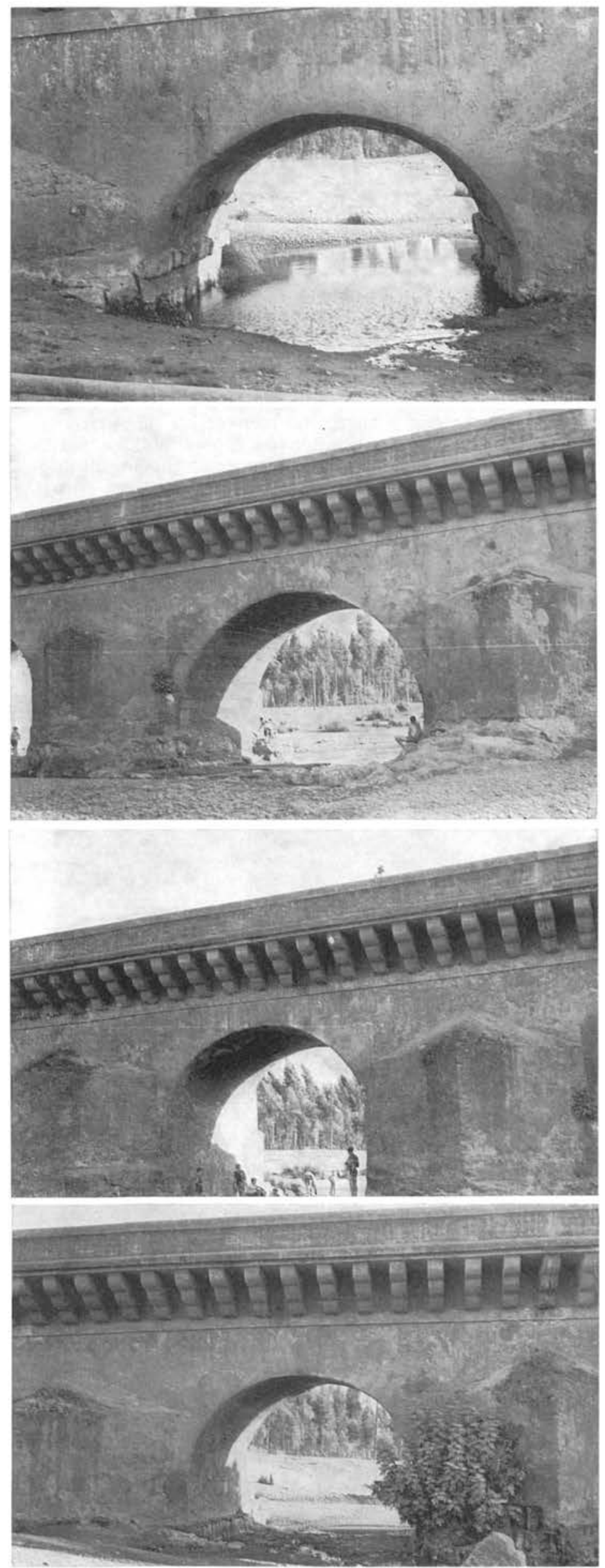

Sucesión de arcos vistos desde aguas arriba a partir de la margen izquierda (los mens
lones que vuelan el pretil son modernos).

sulmanes emplearon artillería (la primera vez en nuestro país), quedó en poder del castellano toda la zona de la calzada hasta Ayamonte y Faro.

Vamos a analizar las características de las arcadas, vano a vano, desde aguas arriba, empezando por la izquierda. (Esta es la posición que adoptamos normalmente, pues el río tiene sentido vectorial y no es lógico ponerse en desacuerdo con él, a contracorriente). La rasante sube, pues el cauce es asimétrico y hay una notable diferencia de nivel entre las márgenes; ya hemos indicado que al cruzarlo el camino tiende a situarse ventajosamente en altura, pero primitivamente debía existir un quiebro de rasantes que, aunque no llegaba a conseguir dos vertientes, establecía una transición ritual. También la rampa de entrada era más fuerte, lo que se contrasta actualmente por la variación de las alturas de tímpanos sobre las claves, disminuyendo, sucesivamente, con la nueva rasante única establecida en la última reforma ya indicada.

El primer arco, que tiene la luz mínima, es menos de medio punto y arranca casi del nivel de aguas, dejando lugar a bastante tímpano hasta el nivel de cornisa. Su sillería destaca netamente en el intradós de la bóveda, con dos hiladas de dovelas en saliente, una marcando los arranques y otras dos aproximadamente a los tercios de la flecha. La boquilla aunque enfoscada transparenta su espesor.

En el segundo arco el nivel del cauce ha descendido $y$ el medio punto, aunque de mayor diámetro que el anterior, tiene altura para desarrollarse integro y aún dejar 
Arcos vistos desde aguas abajo.

Sexto, con arcada ojival de ladrillo.

Séptimo, con boquilla escalonada peraltada. Detalles de fábrica en arco séptimo.

Arco noveno en extremidad.

que la bóveda se prolongue en hastiales verticales, merced a la elevación de sus arranques. Aunque concienzudamente enfoscada deja ver su fábrica de piedra muy alterada y sustituida en zonas por remiendos de fábrica de ladrillo, especialmente en el arranque derecho.

El tercero eleva su clave hasta tocar la cornisa, lo que le permite destacar la silueta de las dos pilas que le corresponden. También están muy enfoscados sus paramentos, pero las boquillas transparentan sillería.

La cuarta bóveda vuelve a tener aparente el trasdós, aunque con mucho rejuntado entre dovelas, cuya piedra se ha deteriorado menos. La clave de su boquilla queda a corta distancia de la cornisa, no llegando a encajar el medio punto al arrancar desde dos asomos de roca sana en los que sus dos pilas quedan directamente sustentadas. Las boquillas transparentan unas hermosas dovelas.

El arco quinto central de la ordenación está reconstruido en hormigón, a consecuencia de nuestra última guerra civil; la destrucción debió ser completa, pues los nuevos tímpanos llegan casi hasta los ejes de pilas, en cambio los tajamares no parecen afectados.

El arco sexto es el primero apuntado, aunque con ojiva tímida, y de fábrica de ladrillo que aparece muy clara en las boquillas, cuyos vértices superiores llegan a la cornisa.

El arco séptimo es un arco indeciso peraltado respecto al medio punto, y tan ligeramente apuntado que no puede calificarse de ojival, con una característica muy medieval en su boquilla que se descom-

Arcos vistos desde aguas arriba.
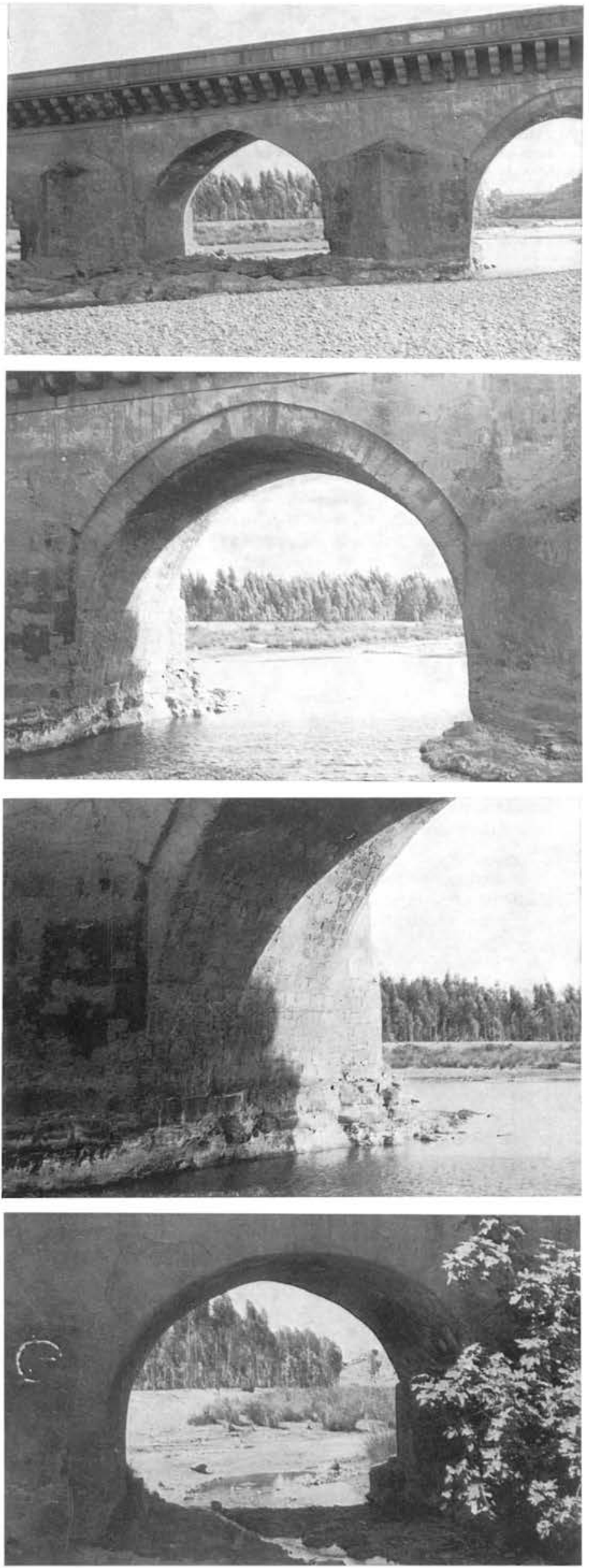
Vistas sucesivas desde aguas abajo: Arcos primero y segundo.

Arcos quinto a tercero.

Arcos noveno a sexto.

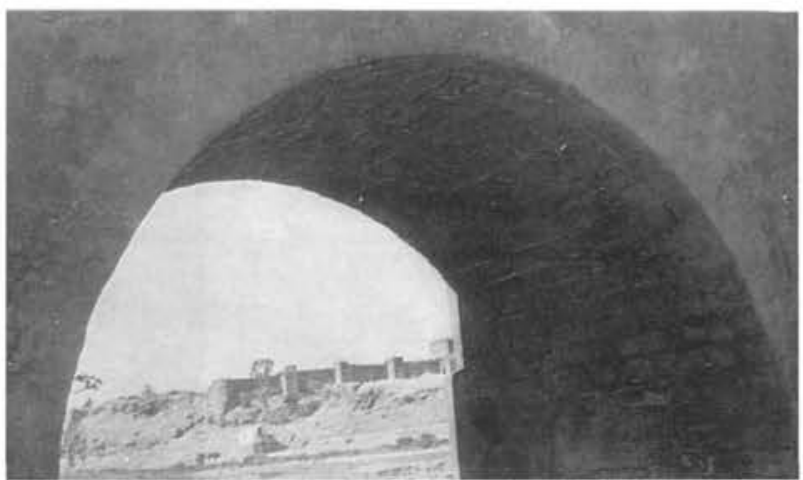

pone en dos roscas, la inferior rehundida con respecto al plano general de paramentos y la superior enrasada ya con este plano de menor espesor, pues tiene sillares casi cuadrados. La alteración de la piedra es menos fuerte y no se ha enfoscado nada más que la superficie de tímpanos, Las pilas arrancan también de roca sobre la superficie de aguas medias. Se observa una gran diferencia entre los sillares que aparecen en los basamentos de las pilas y los de la bóveda propiamente dicha.

Los arcos octavo y noveno son de sillares y su forma tiende al medio punto pero con una factura mucho más descuidada; tienen reparaciones en fábrica de ladrillo. Están bien cimentados, pues la roca aparece superficial.

Si analizamos los elementos complementarios, tajamares y frentes de aguas abajo los encontramos muy ajustados a las normas romanas, prismas triangulares aguas arriba y cilindros semicirculares aguas abajo; quizás han aumentado en planta desde su primer formato, recreciéndose en toda la altura o bien sólo en un cuerpo inferior, prevaleciendo la norma primera para los de aguas arriba y la segunda para los de aguas abajo. En éstos el cuerpo cilíndrico en torreón debe ser posterior, quizás de época de Carlos V. Se han reformado los cimientos en épocas inciertas, y también en la última, pero no son reformas sustanciales, ya que el lecho del río es roca.

En resumen, descartando los ar$\cos 4,5,6$ y 7, los otros cinco no tienen por qué no ser romanos. Volveremos a ocuparnos de aquéllos en los artículos correspondientes a las épocas que les atribuimos. 


\section{puente de Ecija}

Está situado sobre el río Genil junto a la ciudad de Ecija, antigua Astigi, y sirve actualmente a la carretera de Andalucía, habiendo sido originario de la vía de Córdoba a Hispalis, dando entrada a la mansión de la vía Cástulo-Corbuba del Itinerario de Antonino. Lo citan los árabes según referencias de Torres Balbás.

Es lo más verosímil que el puente actual sea transformación del primitivo con la misma ubicación, pero la última reforma en el siglo XVIII, en tiempos de Carlos III, lo enmascaró totalmente con un nuevo recubrimiento de paramentos, y el embalse correspondiente a la presa próxima aguas abajo ha ocultado el cauce, por lo cual no puede asegurarse nada a este respecto.

Tiene once arcos, aunque según grabados parece que en otra época tuvo sólo nueve que son de medio punto; como consecuencia de la subida de nivel debida al represamiento se han sumergido los arranques y no llegan a dar círculo completo al proyectarse en el espejo permanente y casi siempre sereno de la superficie líquida.

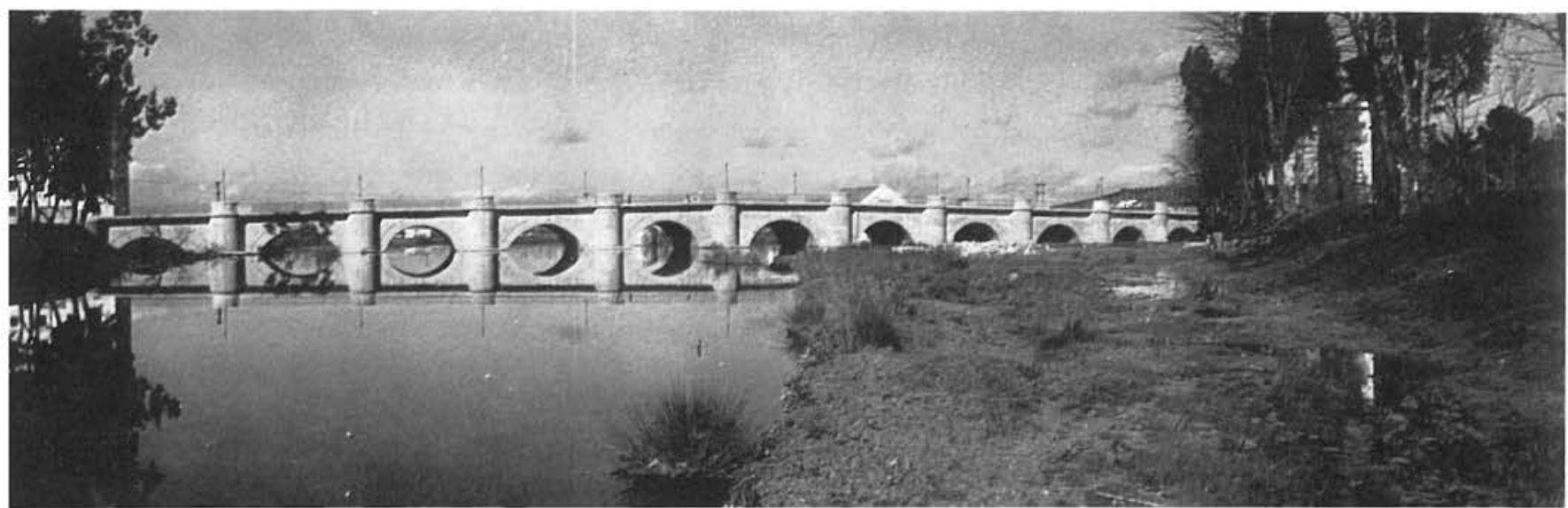

Vista frontal desde aguas arriba.

Escorzo desde aguas abajo.

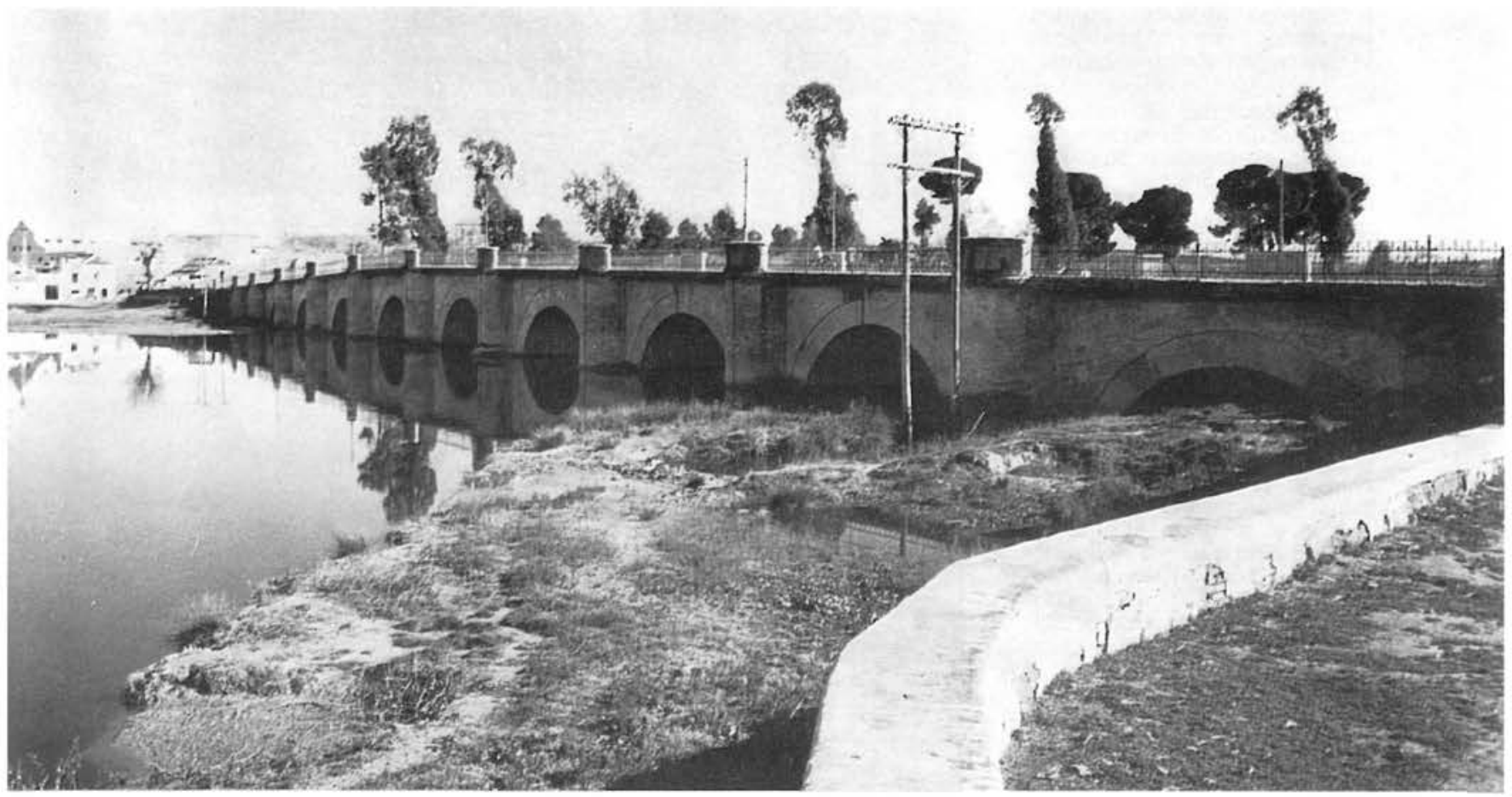




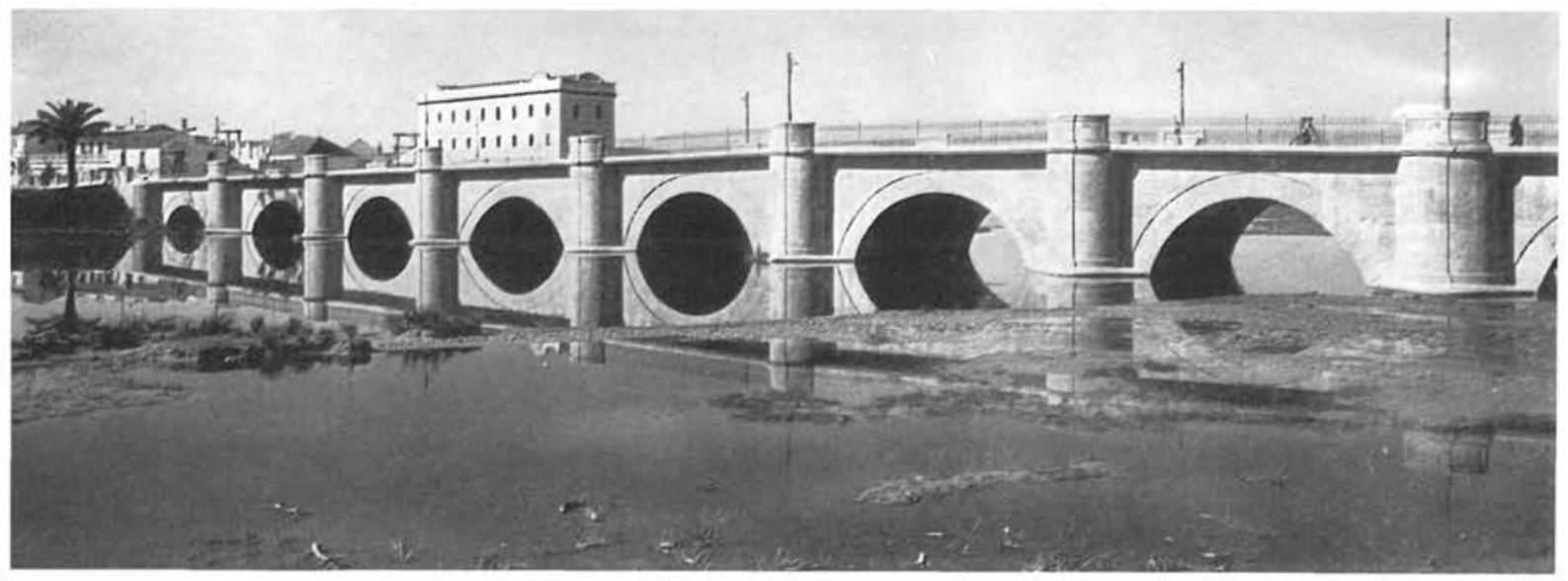

Vista desde aguas arriba. A la izquierda, la ciudad de Ecija.

Los vanos tienen una luz de 10,20 iguales entre sí teóricamente y separados por macizos de anchura igual al tercio de la misma; sus boquillas están rehundidas respecto al plano de paramento y tienen 3,5 pies de espesor.

Las zonas de tímpanos entre arcos están tapiadas por cuerpos cilíndricos cuya planta desarrolla más de medio círculo con salientes en doble anillo formando como basa y capitel, la basa descansando sobre un ensanchamiento de cimientos y el capitel recrecido en un balconcillo con la altura de la barandilla, ensanchamiento y recrecimiento que deben ser obras posteriores, especialmente esta última que puede corresponder al ensanche de la plataforma volando aceras entre los cuerpos cilíndricos sin utilizar todo su saliente y llevando hacia afuera las cornisas que en un primer momento resaltarían simple mente la coronación de tímpanos. Los balconcillos y cornisa volada dejan de ser de ladrillo, teniendo aquéllos un mal revoco sobre hormigón.

Las superficies del fuste cilíndrico de los cuerpos salientes están recrecidas mediante tres fajas verticales de poco relieve, una central en el frente y dos en el empalme con los paramentos de tímpanos adyacentes, El aparejo de las boquillas es de ladrillos a soga y tizón en juntas radiales alternando en juntas circunferenciales.

En los tímpanos tenemos hiladas horizontales continuando las de los cuerpos salientes, pero se interrumpen en falsa boquilla de 1 pie de profundidad que rebordeara todo el saliente correspondiente al rehundido de la au téntica boquilla, con lo cual se establece una transición entre el aparejo de ésta y el de los tímpanos, evitando que las hiladas de éstos queden recortadas con oblicuidades variables por dicho reborde.

Al ensanchar la calzada, obra que debió llevarse a cabo por el Circuito Nacional de Firmes Especiales, se sustituyó el pretil, que seguramente se conservaba hasta entonces, por barandilla metálica entre los balconcillos.

Como el puente en la situación actual corresponde al siglo XVIII, volveremos a él cuando tratemos de los puentes de esta época. Los grabados que reproducimos corresponden el primero a la situación en el siglo XVI con tajamares cortantes muy avanzados; el segundo es una interpretación directa del anterior, y el tercero es una lito grafía del XIX donde aparece ya la reforma de Carlos III.

Escorzo

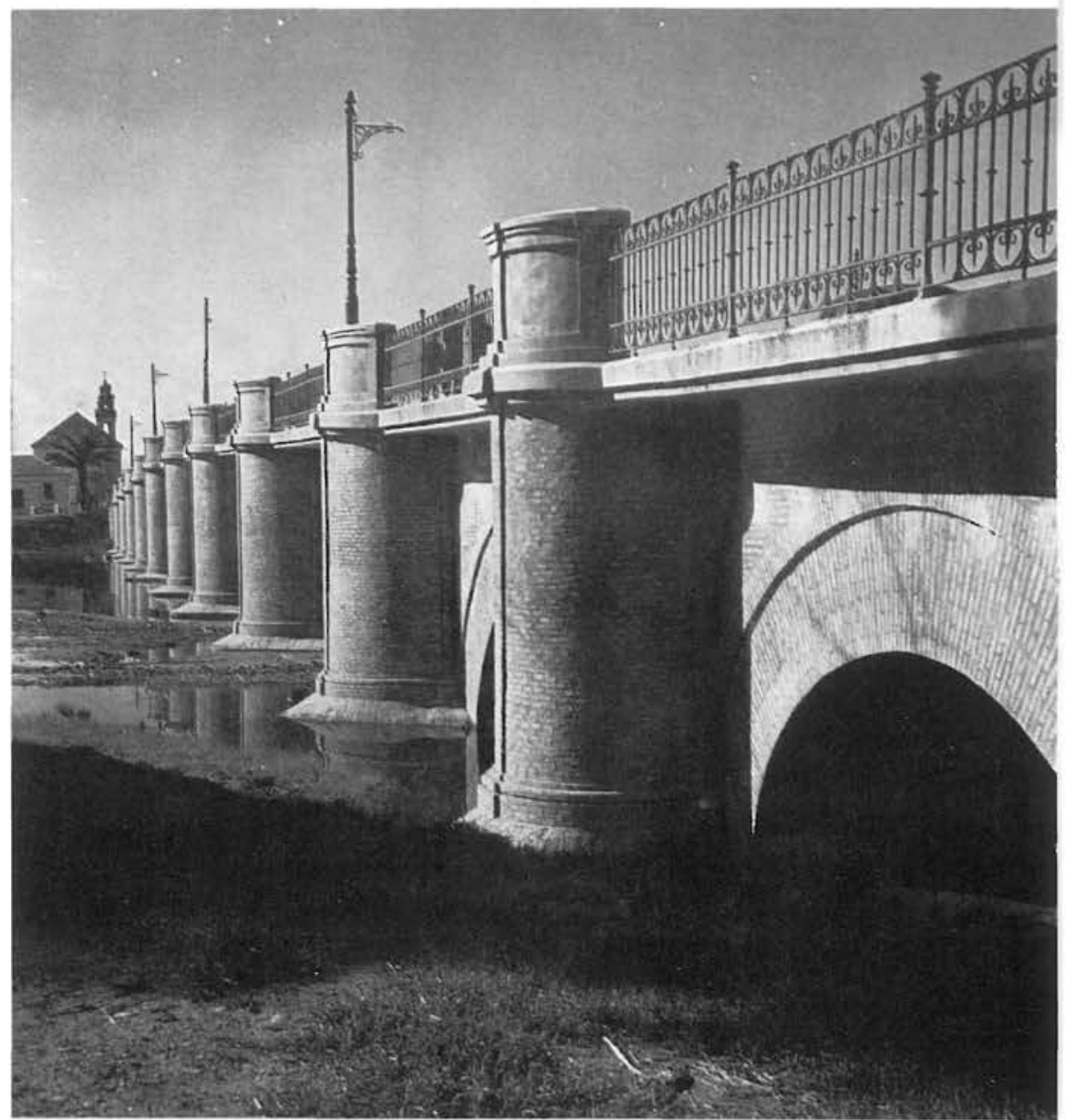



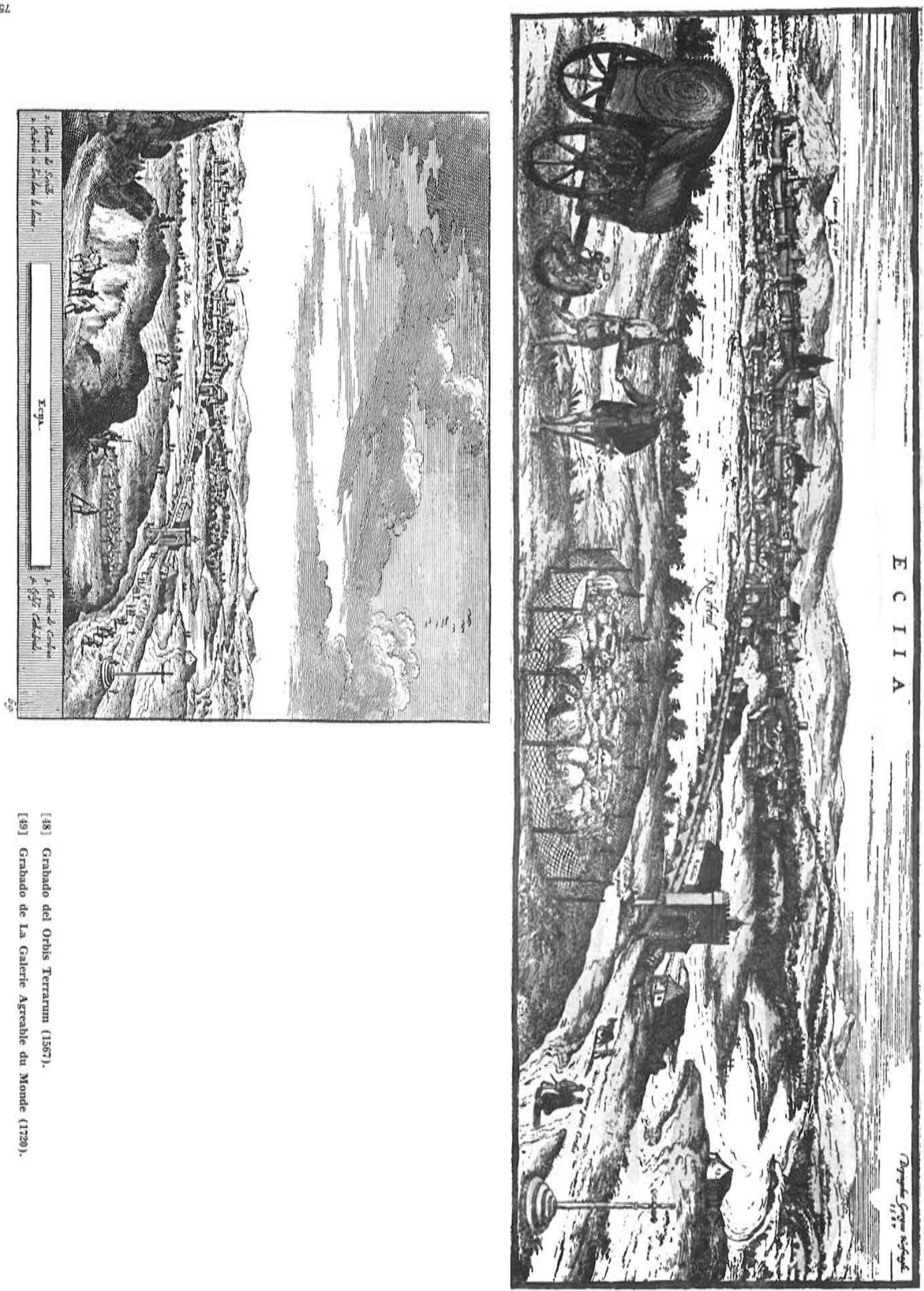


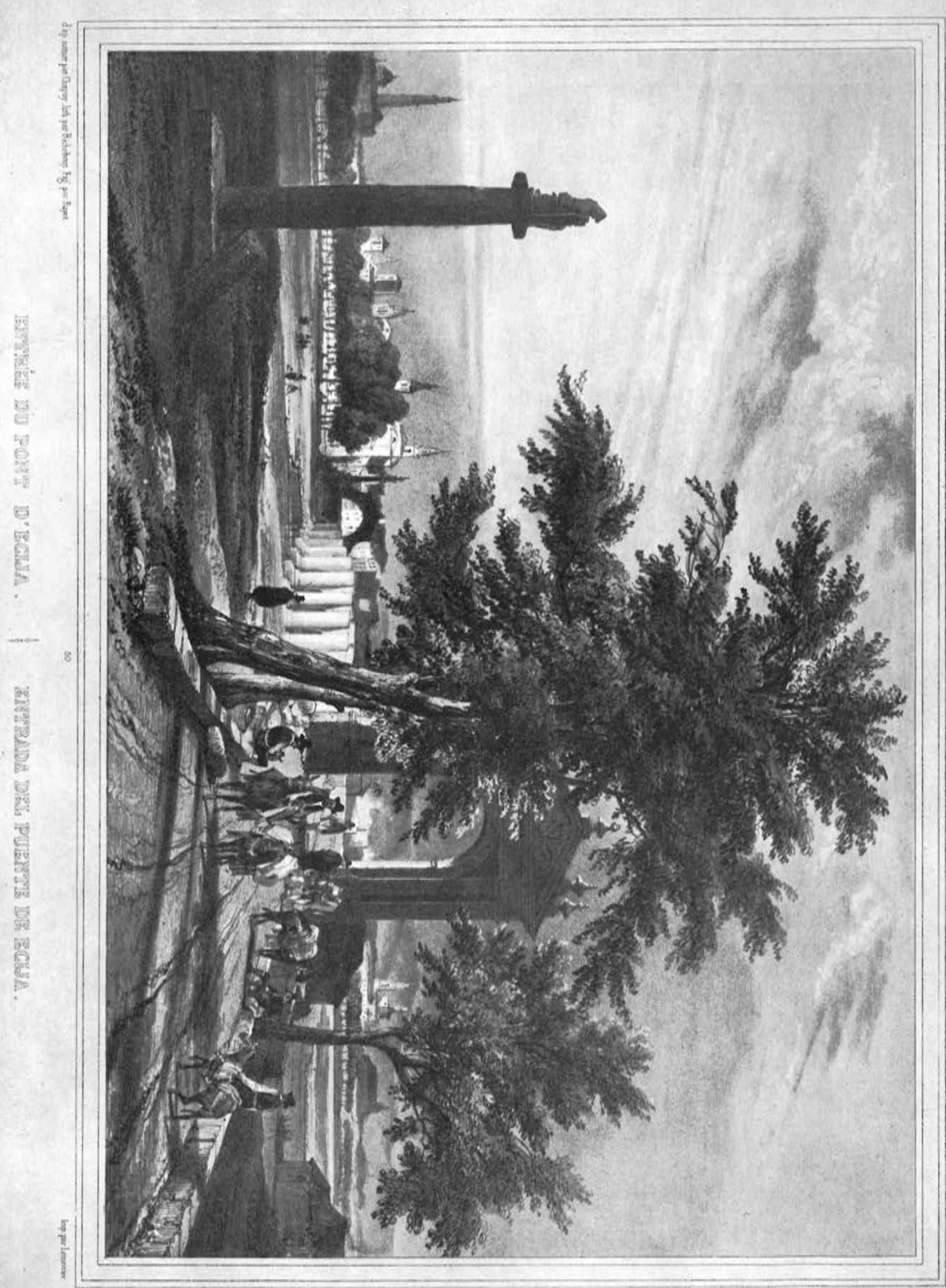




\section{puente de Carmona}

Está situado en la proximidad de la carretera actual, la cual contornea el pueblo ciñéndose con la pendiente admisible a las curvas de nivel, mientras que la via romana se lanzaba a subir directamente hacia Carmona, en seguida de pasar el riachuelo anterior, que es donde divergen vía romana y carretera actual.

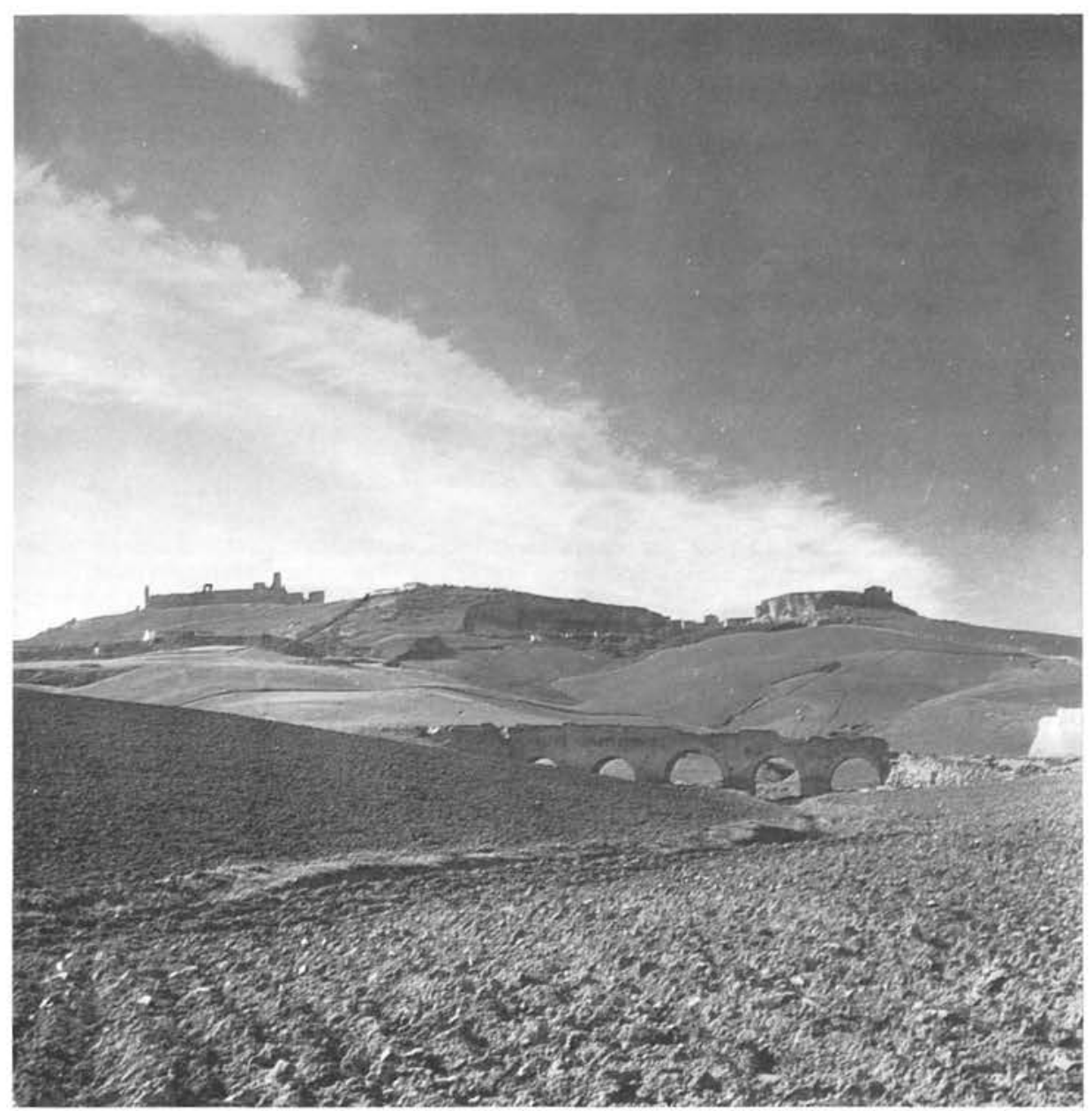

Vista general desde aguas abajo. Sobre el cerro: Carmona.

El cauce que salva es de poca importancia, pues recoge únicamente las aportaciones de dos amplias vaguadas del montículo coronado por la ciudad. El puente sirvió a la carretera general de Andalucía hasta principio de siglo, pero hoy sólo puede servir de atajo a peatones y bestias de carga.

Tiene cinco vanos: el central con la luz máxima de $5,20 \mathrm{~m}$, destacando además por peralte sobre losa; cuatro laterales que deberían tener igual luz de $3,80 \mathrm{~m}$, aunque uno de los extremos la rebasa en $0,40 \mathrm{~m}$. El macizo de las pilas es aproximadamente 


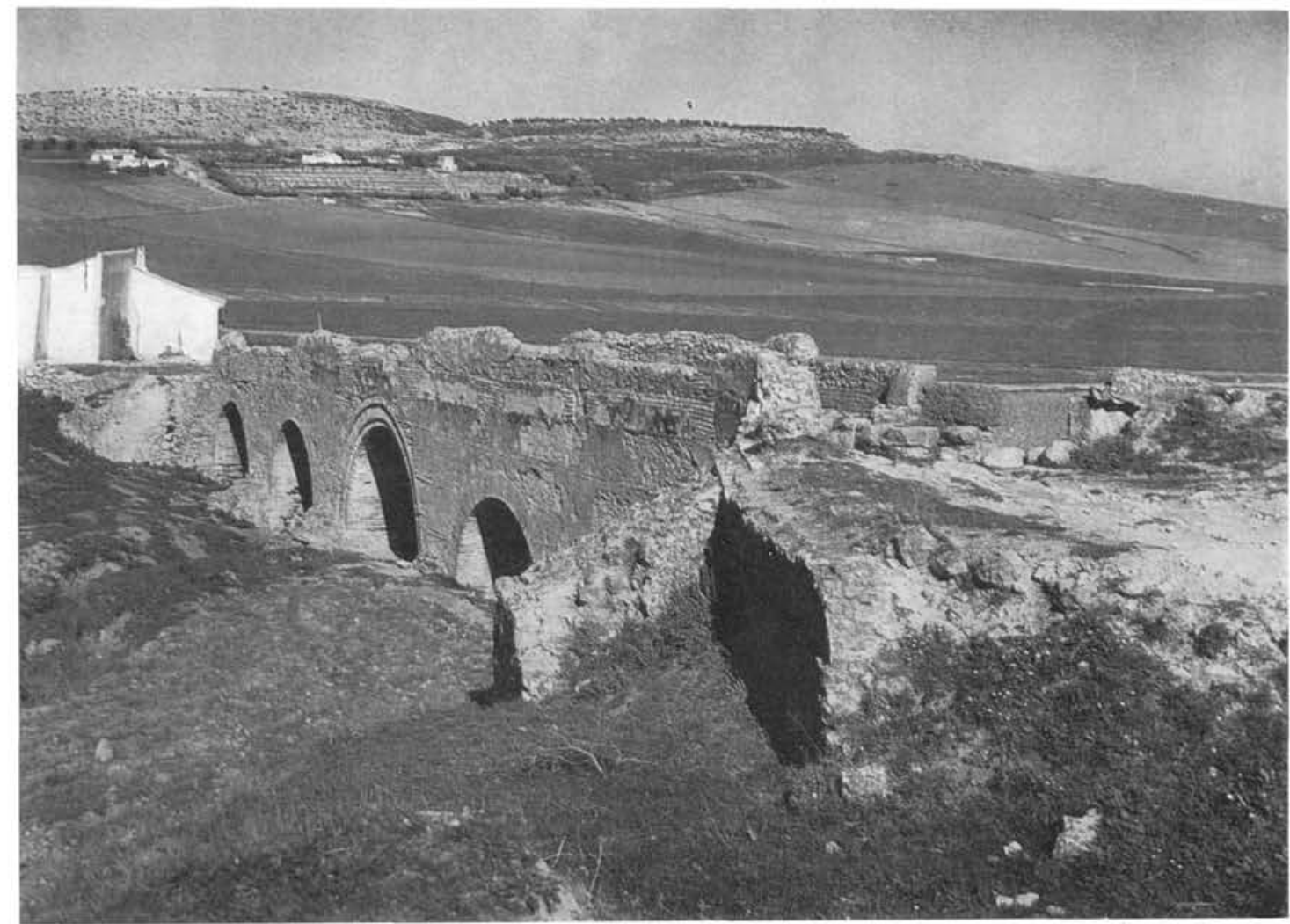

Vista general desde aguas abajo.

igual a la mitad de los vanos. El paso de aguas ha debido desplazarse hacia la margen izquierda, dejando muy disminuido el desagüe de los dos arcos de la derecha cuyos tajamares han quedado enterrados especialmente aguas arriba. En esto ha debido tener parte un contrafuerte del muro de acompañamiento correspondiente, que parece ser obra posterior a la romana.

Unicamente las bóvedas son de opus latericium, pues los tímpanos son de opus mixtum y las pilas de opus cuadratum descuidada en superficie, con un núcleo de opus cementicium. También era de esta

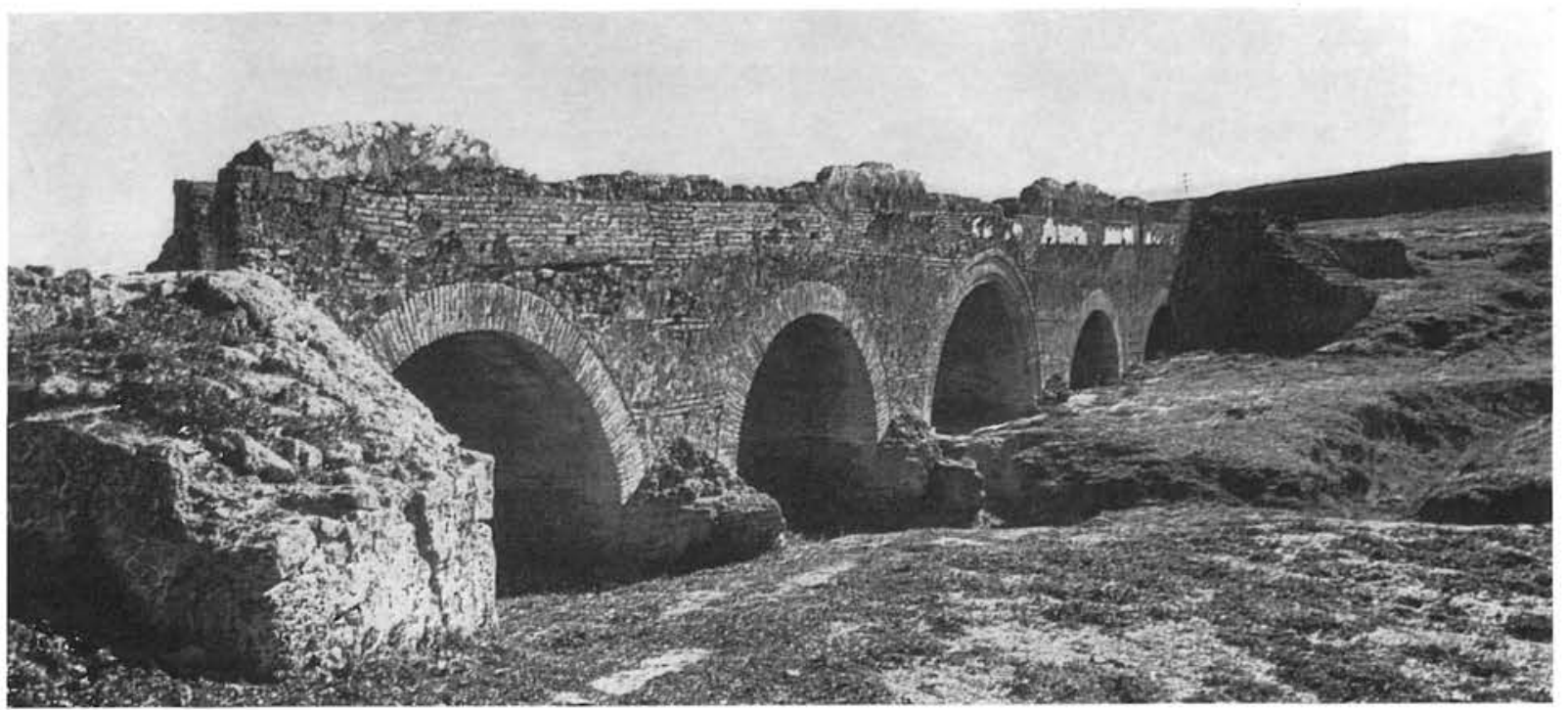

Vista general desde aguas arriba. 

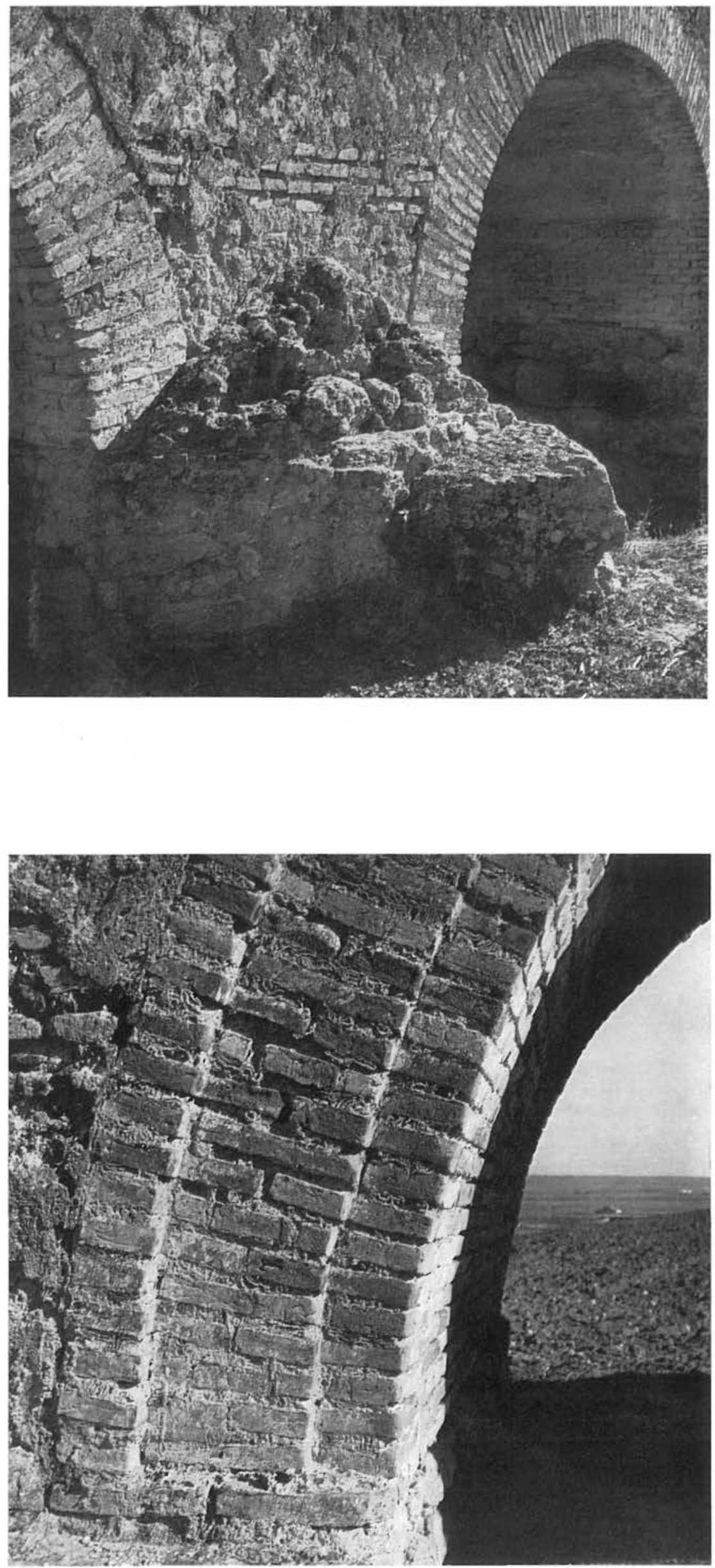

Detalle de la pila $y$ enjutado de tímpanos.

Detalle de la boquilla del arco principal.

última fábrica el relleno de tímpanos. Coronando tímpanos desde el trasdós de clave del arco central aparecen ocho hiladas de ladrillo que hacen de pretil por el lado interno, aunque éste se completa mediante un recrecimiento de mampostería como la de los recuadros de opus incertum en paramentos de tímpanos.

En la calzada aparecen en zona central los trasdosados de ladrillo de las bóvedas desgastados y deteriorados por el tráfico, con rehundidos en la fábrica correspondiente a relleno de tímpanos, y a ambos lados, formando como andenes, unas losas de bastante grueso que no delimitan claramente zonas reservadas a peatones, defendidos del tráfico rodado, por lo cual queda la duda de si en un principio formarian parte de un revestimiento uniforme en toda la superficie de circulación, pues no es lógico que se hubieran dejado los ladrillos al descubierto como pavimento en la zona de rodadura. Refuerza esta opinión la altura tan importante del pretil con una zona inferior de fábrica de ladrillo recrecida por mampostería, fábricas que están enlazadas, sólo por la cara interna, mediante piedras verticales conformadas como ambones para evitar el acercamiento de los vehículos a los pretiles. Otra hipótesis también verosímil es que estas losas y el recrecimiento de los pretiles hayan sido obra posterior.

Los muros de acompañamiento a ambos lados, complementados por con- 


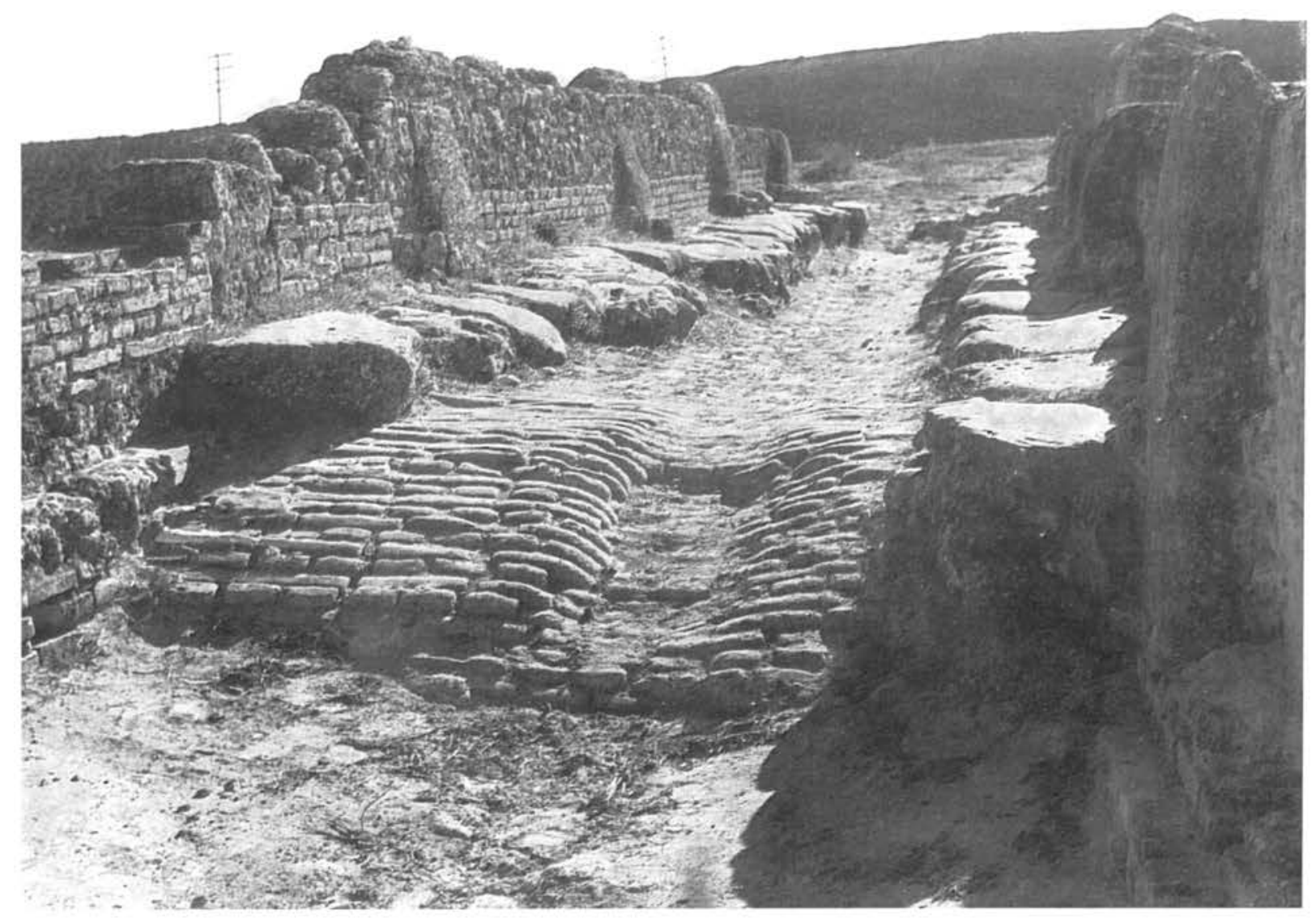

Calzada, andenes y pretiles del puente.

trafuertes de encauzamiento y refuerzo todos ellos de mampostería atípica poco cuidada, parecen ser obras de acomodación posterior.

A excepción de la bóveda central, que tiene la boquilla en tripartición de roscas independientes terminando en planos distintos, las demás poseen boquillas simples enrasando con paramentos de tímpanos que son únicos desde coronación a pilas. Su espesor de pie y medio da lugar a un aparejo muy simple con alternancia de juntas de un modo regular. En el intradós de las bóvedas aparecen las hiladas en superposición de soga y tizón con toda regularidad. En la boquilla del arco central que rompe el plano único de paramentos como ya hemos indicado tenemos boquillas de a pie donde también alternan soga y tizón entre otras dos de medio pie; correspondiendo a una de éstas, la de mayor radio, enrasar con el plano de paramento y quedando rehundidas las otras dos con escalón de unos $6 \mathrm{~cm}$.

La fábrica mixta de los tímpanos se arma con mampostería (opus incertum), recuadrada entre dos verdugadas de dos a cuatro hiladas de ladrillo.

Las pilas son de sillería (opus quadratum) poco cuidada con tajamares triangulares en los frentes de aguas arriba, coronadas de sombreretes piramidales y cuerpos semicirculares adosados aguas abajo. La caliza de que están construidas es bastante cavernosa y se halla muy meteorizada.

A pesar de la deterioración de las fábricas y de las reparaciones torpes que ha sufrido, la obra tiene un empaque que no va de acuerdo con la poca importancia del cauce, al menos en la actualidad. 


\section{puente de Aznalcázar}

Estaba situado en el río Guadiamar cerca del pueblo de Aznalcázar (provincia de Sevilla) y sirvió a la comunicación de Sevilla a Huelva dentro de la vía romana Ostio Fluminis Anae a Emérita (Ayamonte-Mérida) del Itinerario de Antonino.

Según Madoz el puente tuvo «catorce ojos", pero actualmente (año 1952) no quedan más que cinco de la extremidad correspondiente al pueblo que le da nombre. Sufrió numerosas restauraciones, algunas documentadas por las actas del Cabildo de Aznalcázar que se citan en el Catálogo Arqueológico y Artístico de la provincia de Sevilla (ver referencia), en los que se pide ayuda a la capital (1550-1606-1724) para hacer las reparaciones. En la tercera se habla de upuente de pieđran; y aunque parece lo más verosímil que el puente fuera originalmente todo de ladrillo, en algunas de las reconstrucciones se emplearía la piedra para las zonas principales, ya que la altura de rasante sobre el río fue importante en la zona central, 20 varas, según Madoz.

La zona conservada es de muy poca altura y los arcos no llegan a destacar sus medios puntos completos. Es el tipo clásico de paramento enrasado en plano único por ambos frentes, con la variante de que las boquillas se subdividen en dos roscas de las cuales la inferior queda rehundida respecto a ese plano, quedando la superior que es sólo "de boquilla» enrasada a paramento. El espesor de las roscas es de pie y medio, alternando juntas, que es también el grueso de la bóveda real, que aparece al descubierto muy bien trasdosada e independiente del relleno de tímpanos. Estos son de un pie de espesor con relleno de "opus cementiciaen.

El cimiento debió ser bueno, pues aparece la roca en asomos que se incrustan ascendentemente en las fábricas. Parece que en su última época tenía un terraplén recrecido con respecto a la rasante original que debía ser a dos vertientes.

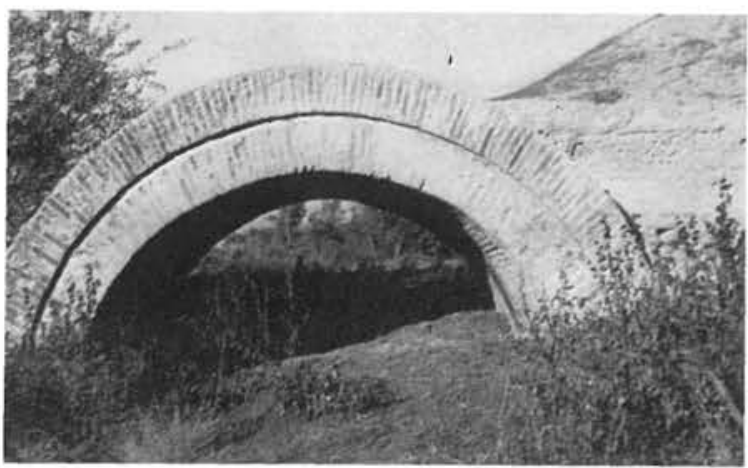

Diferentes vistas de las ruinas de los cinco ojos que se conservan (1952).
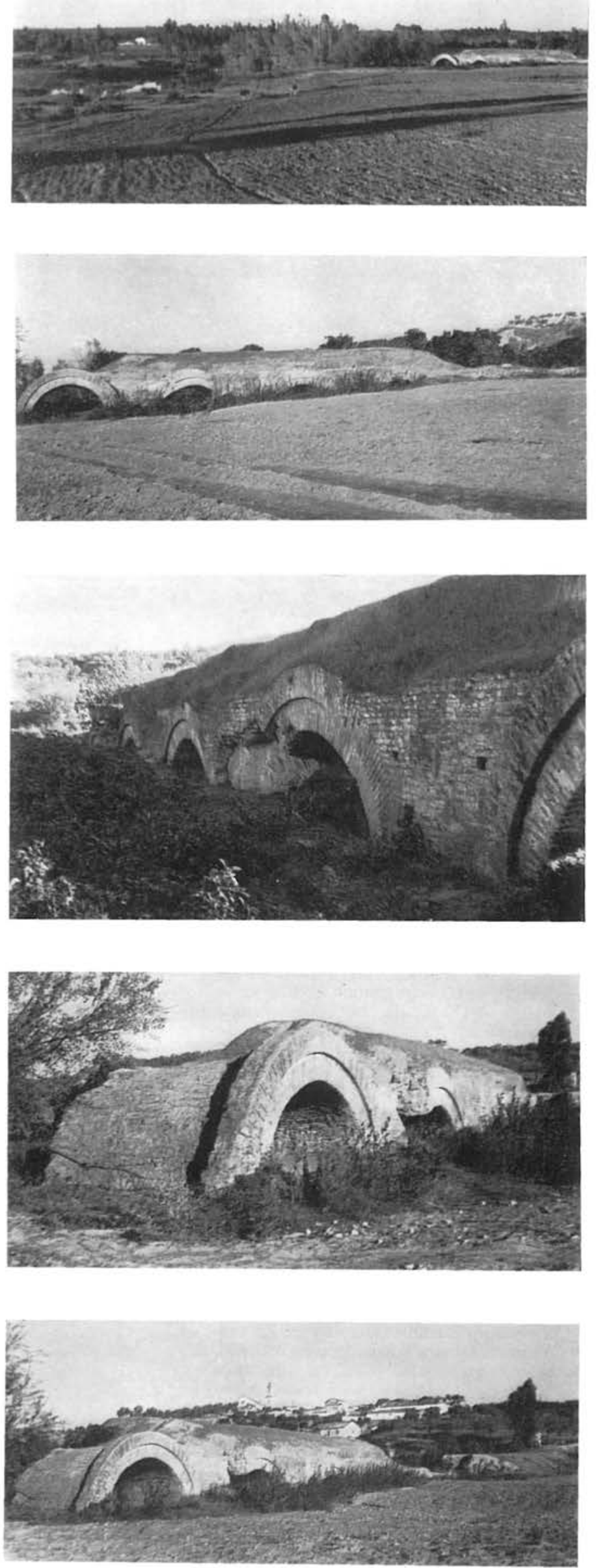


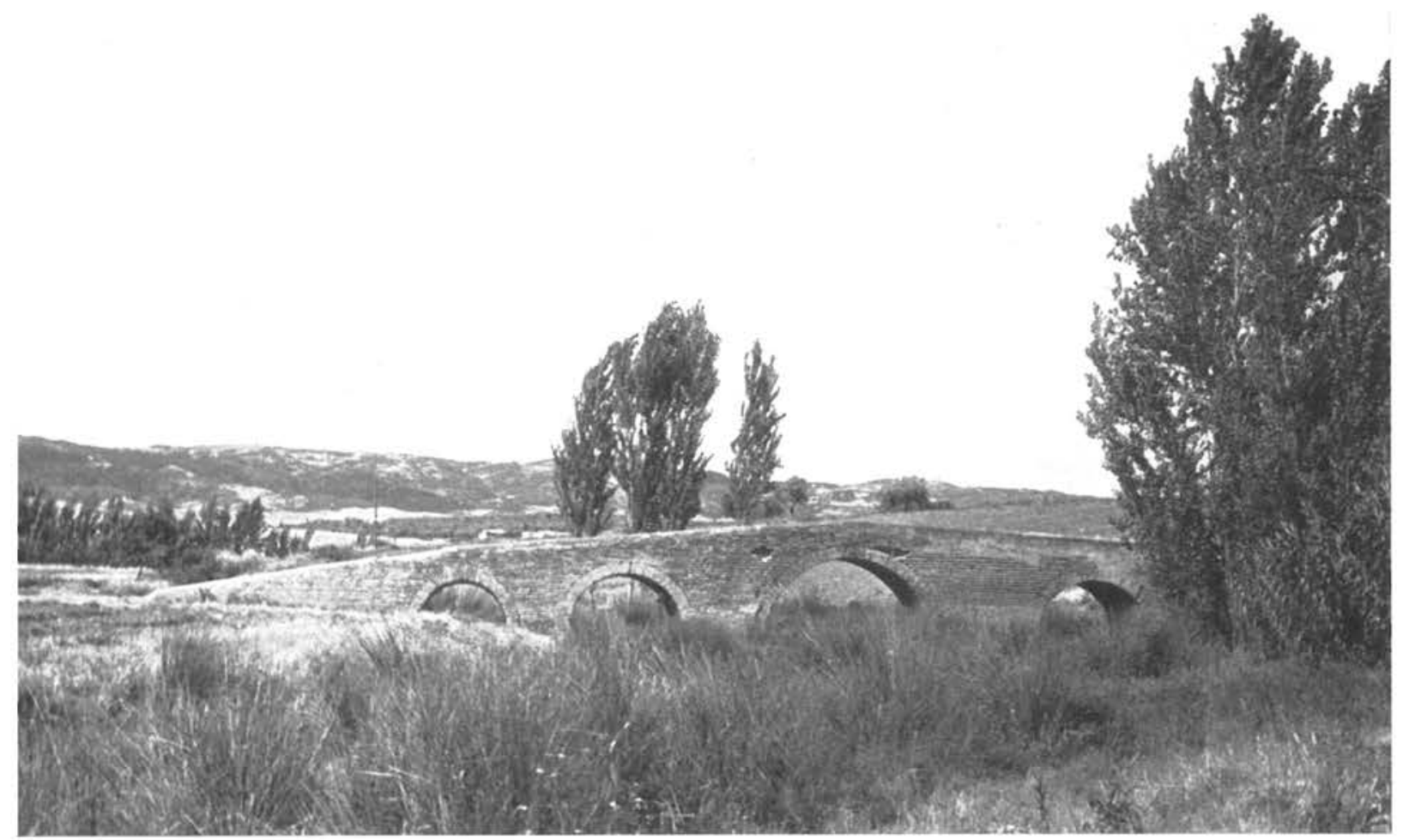

Vista general desde aguas abajo.

Vista en escorzo desde aguas abajo.

\section{puente del arroyo Molino}

Está situado en el camino de Andújar al puente del Jándula — del cual ya nos hemos ocupado- y sobre el arroyo del Molino, en la provincia de Jaén. No tenemos referencia de este puente, que encontramos al buscar el puente del Jándula. Lo consideramos romano por la sencilla perfección de su fábrica: dos planos paralelos definen su volumen que se perforó por cinco huecos, aunque actualmente son cuatro, pero el quinto debió desaparecer al efectuar la reforma del acompañamiento en orilla derecha que introduce un plano discordante quebrando la uniformidad de paramentos en tipo de fábrica e inclinación.

La distribución de luces es análoga a la del puente de Carmona: un arco central de mayor importancia, luz 3,60, y en simetría dos arcos a cada lado de luces ligeramente decrecientes. La sencillez de fábrica y aparejos es realmente extraordinaria, pues los tímpanos con hiladas horizontales a soga simplemente alternando juntas se prolongan hasta la coronación a dos vertientes sin alterar el aparejo. Los macizos son

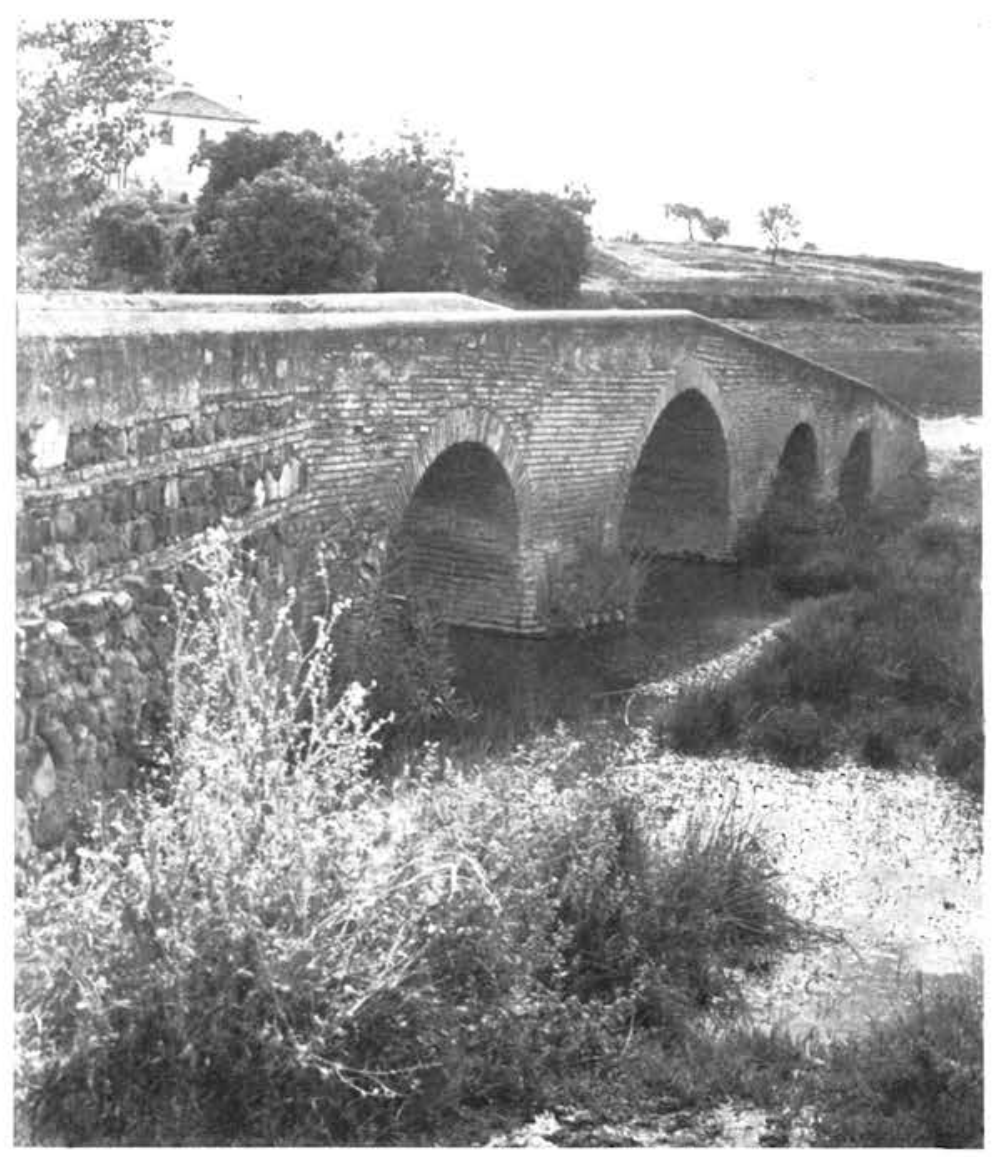


aproximadamente de la mitad del vano mayor que les corresponde. El remate ac tual redondeado y de mampostería no parece romano, sino de la última repa. ración. Este frente uniforme se recorta por las bo. quillas de los arcos todos del mismo espesor un pie de ladrillo que se apareja en alternativa de soga y dos tizones, continuando hasta enterrarse en el te. rreno. No se ve la cimen. tación. El interior de las enjutas es de mampostería (opus incertum) a la cual ha servido de molde la fábrica de ladrillo de medio pie.

La fábrica utilizada en la reforma del acompañamiento es de mampostería bien paramentada con verdugadas de ladrillo que prolongan dos hiladas da la fábrica de tímpanos.

Quedan restos de tajamares triangulares en los frentes de aguas arriba.

La rasante se perfila netamente a dos vertientes, quebrando sobre clave del arco central, que es el actual de mayor luz.

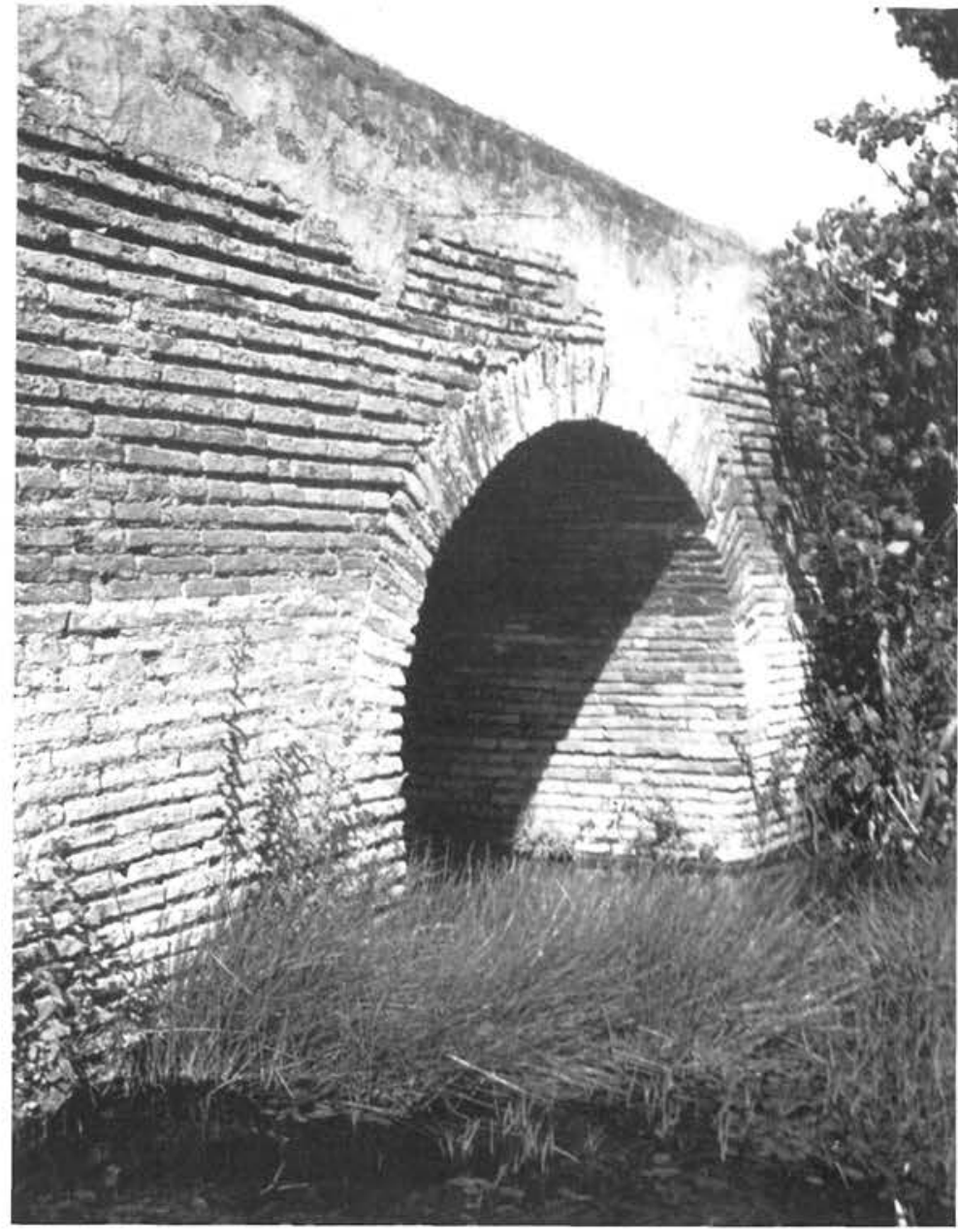

Detalle de un arco.

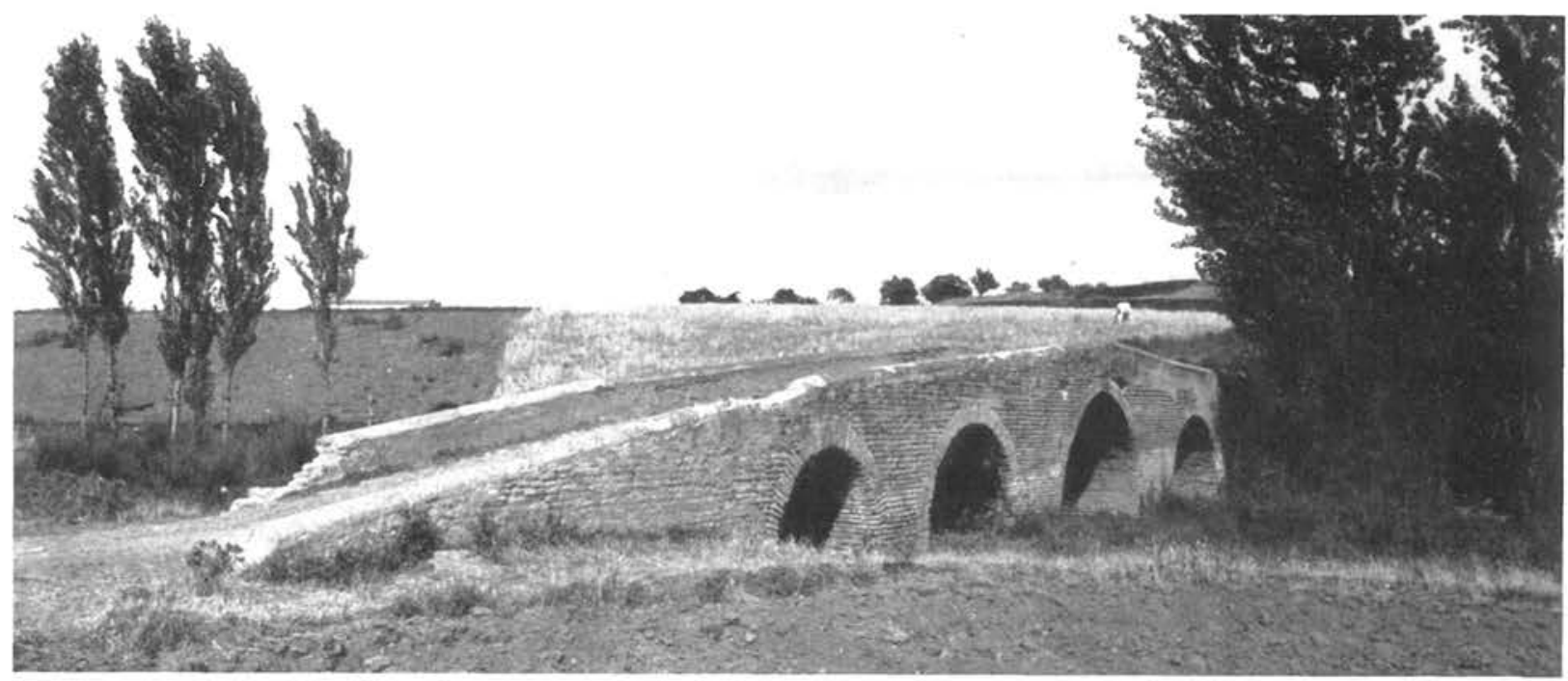

Vista en escorzo desde aguas abajo. 


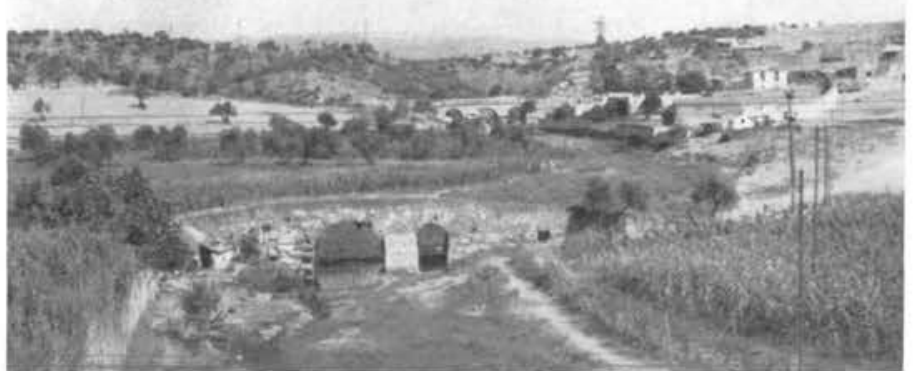

Vista desde el ferrocarril.

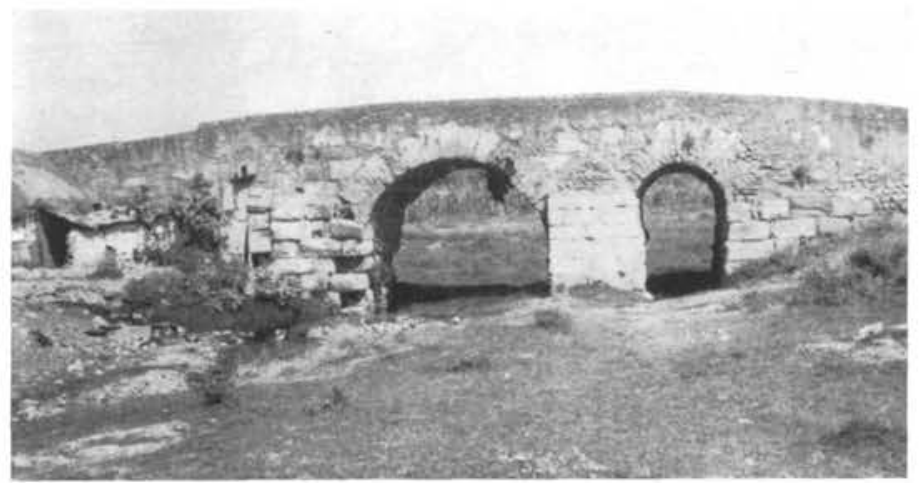

Frente de aguas abajo.

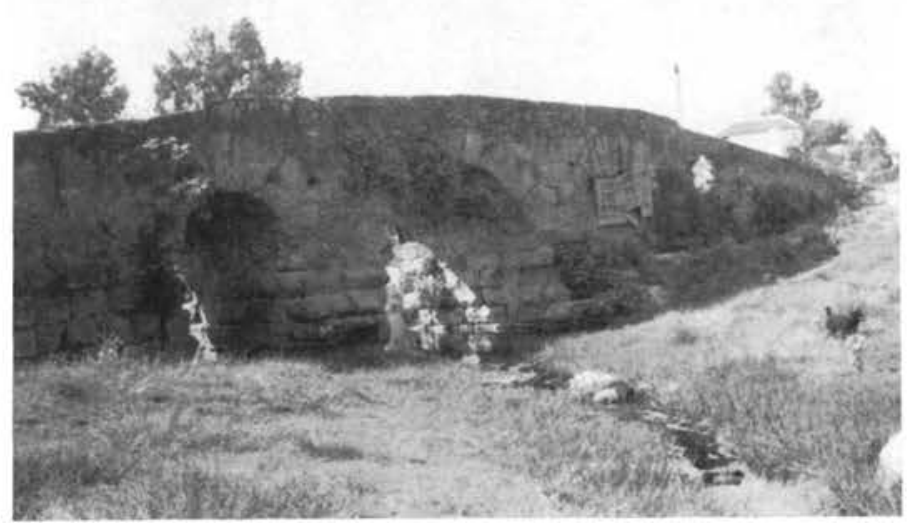

Frente de aguas arriba.

Vano principal.

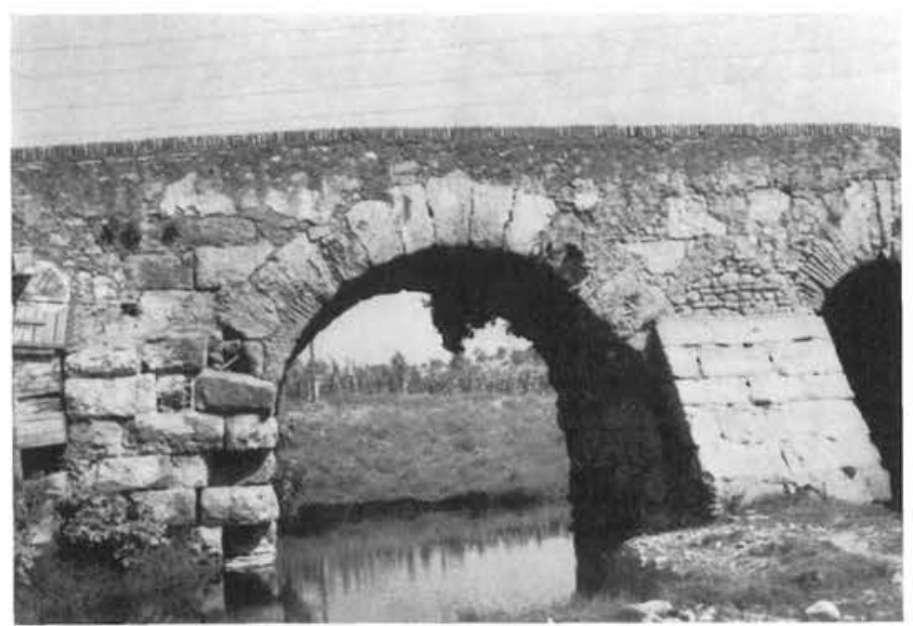

\section{puente \\ de Los Pedroches y alcantarilla del Arroyo de la Buena Agua}

El puente de Los Pedroches sobre el río de este nombre debía corresponder a la vía romana del Guadalquivir, es decir, la de Corduba-Cástulo, entre el actual puente de Alcolea y la ciudad y a una distancia de un kilómetro de aquella. Seguramente en esta zona las vías de ambos lados del Betis se habían reunido en la orilla derecha y llagaban a la ciudad en única vía.

Este puente de tres vanos con uno central de $5,20 \mathrm{~m}$ y dos laterales ambos muy reconstruidos, y probablemente elevado sobre arranques uno de ellos, está dentro del estilo de otro puente similar, el de Villa del Río, en la misma vía Cástulo-Corduba, con tres vanos y coronación a doble vertiente, que ya estudiamos en artículo anterior relativo a los puentes de la época republicana.

La proporción entre vanos es análoga, e incluso las de vanos a macizos, pero en el de Villa del Río se ha corregido la gran latitud de las pilas resultantes intercalando arquillos de aligeramiento que aligeran extraordinariamente el conjunto. También como aquél tiene tajamares triangulares aguas arriba, y frentes planos enrasados con paramentos de tímpanos aguas abajo, aunque en una de las pilas se ha añadido en época posterior un prisma triangular de la misma anchura a guisa de contrafuerte. Pero lo que más acerca estilísticamente ambos puentes es la disposición de dovelas engatilladas en el arco central, donde se mantienen auténticas. 

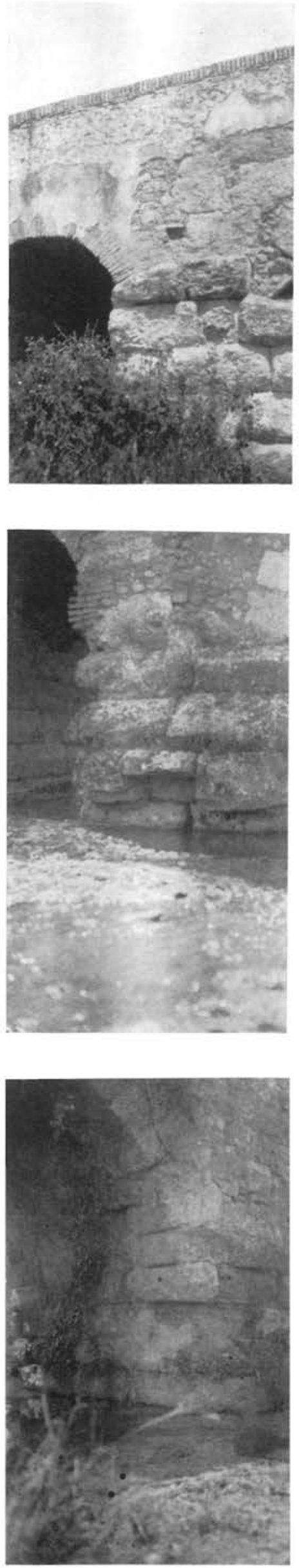
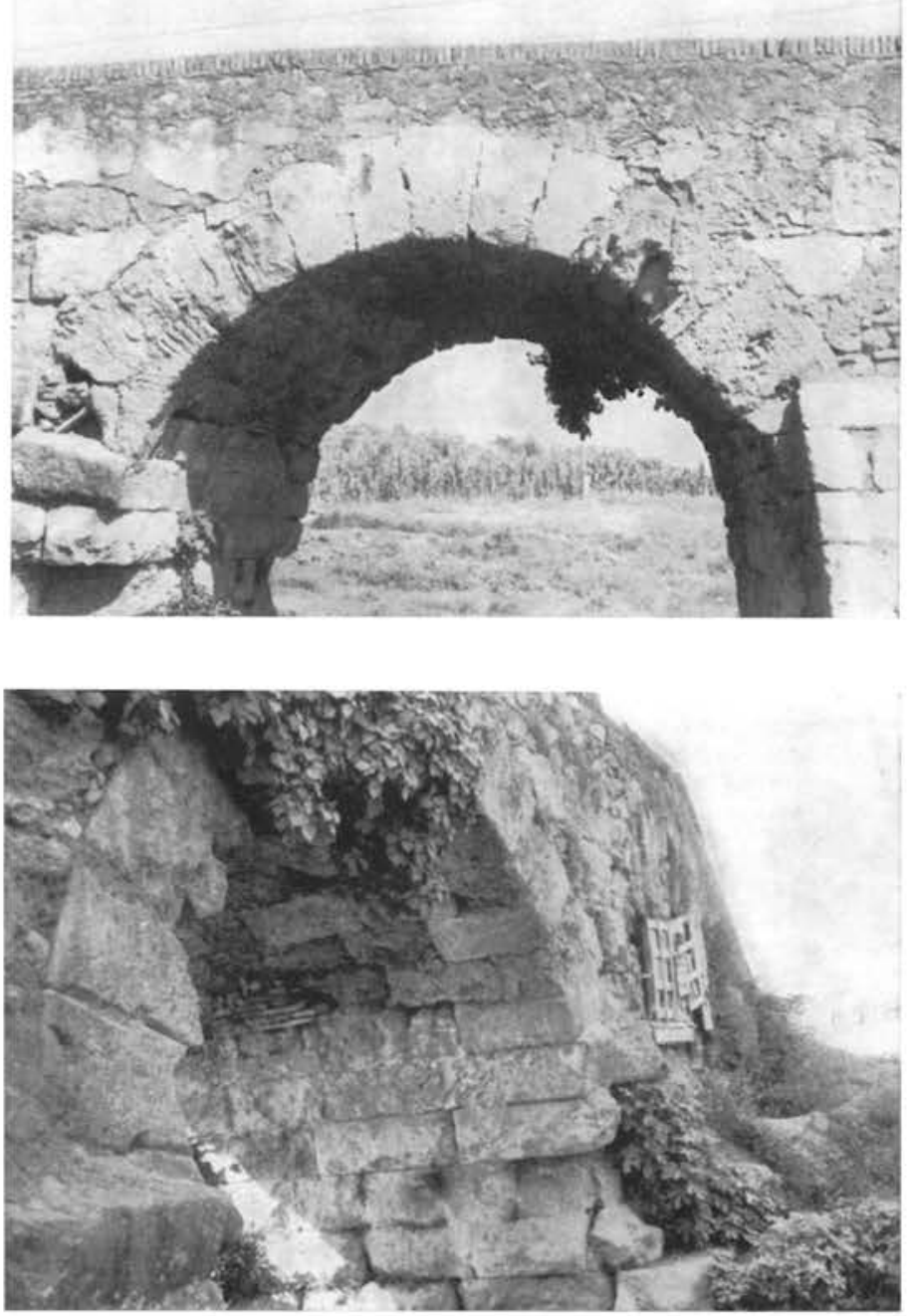

Detalles de los elementos estructurales y de las fábricas del puente de Los Pedroches.

Este engatillado aparece también en otra obra de la misma zona, que es una alcantarilla en medio punto, de $3,65 \mathrm{~m}$ de luz, con dovelas muy perfectas que no sólo tienen engatillado por rediente a media distancia en el espesor de la boquilla, sino que la archivolta se destaca junto a trasdós con retallo bastante perdido de saliente rectangular como en los arcos genuinos del puente de Córdoba. El diseño de las dovelas, a pesar del deterioro grande por meteorización de la arenisca que las constituye, es muy perfecto, y existe también una gran regularidad en las dimensiones aparentes por intradós, donde aparece muy claro el aparejo isodomo de todas las dovelas. En época reciente se ensanchó la obra para acomodar el camino al servicio de la presa del Guadalmellato. Este ensanchamiento se ha hecho sin ningún cuidado, incluso reduciendo el desagüe de la obra mediante boquilla de sillería, tímpano de ladrillo y relleno de fábrica de hormigón.

Arco central desde aguas arriba. 
2
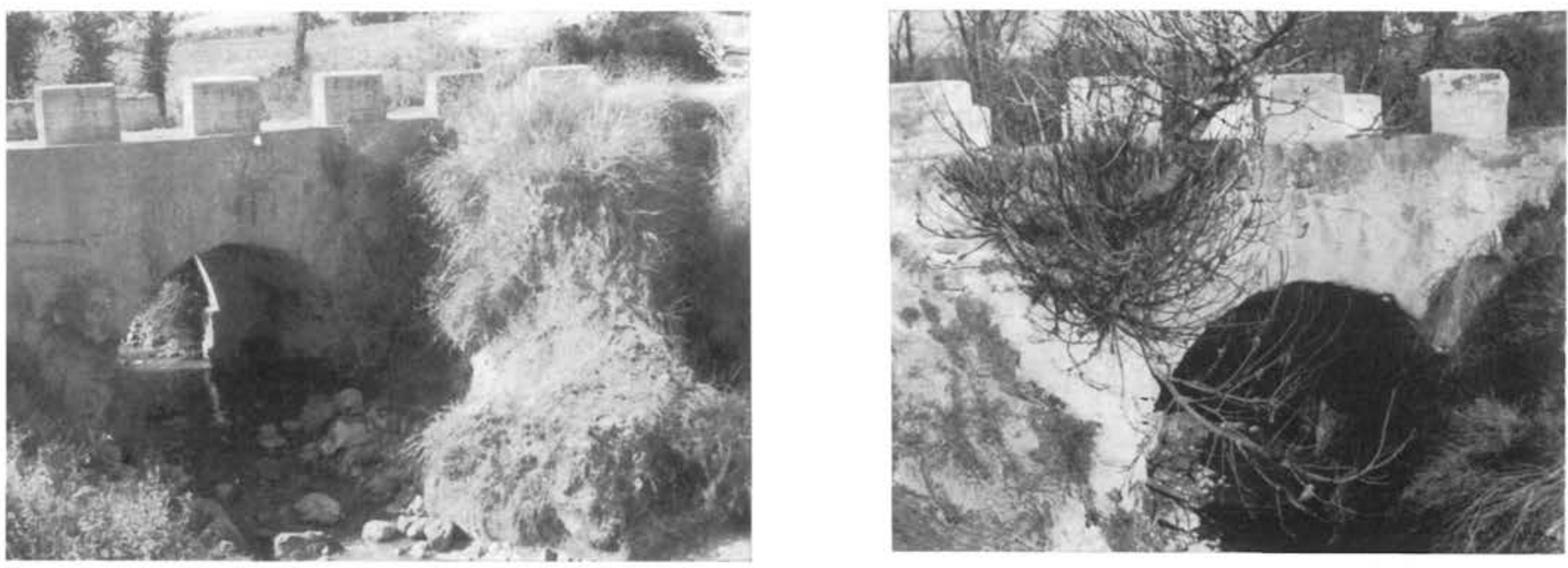

3

4
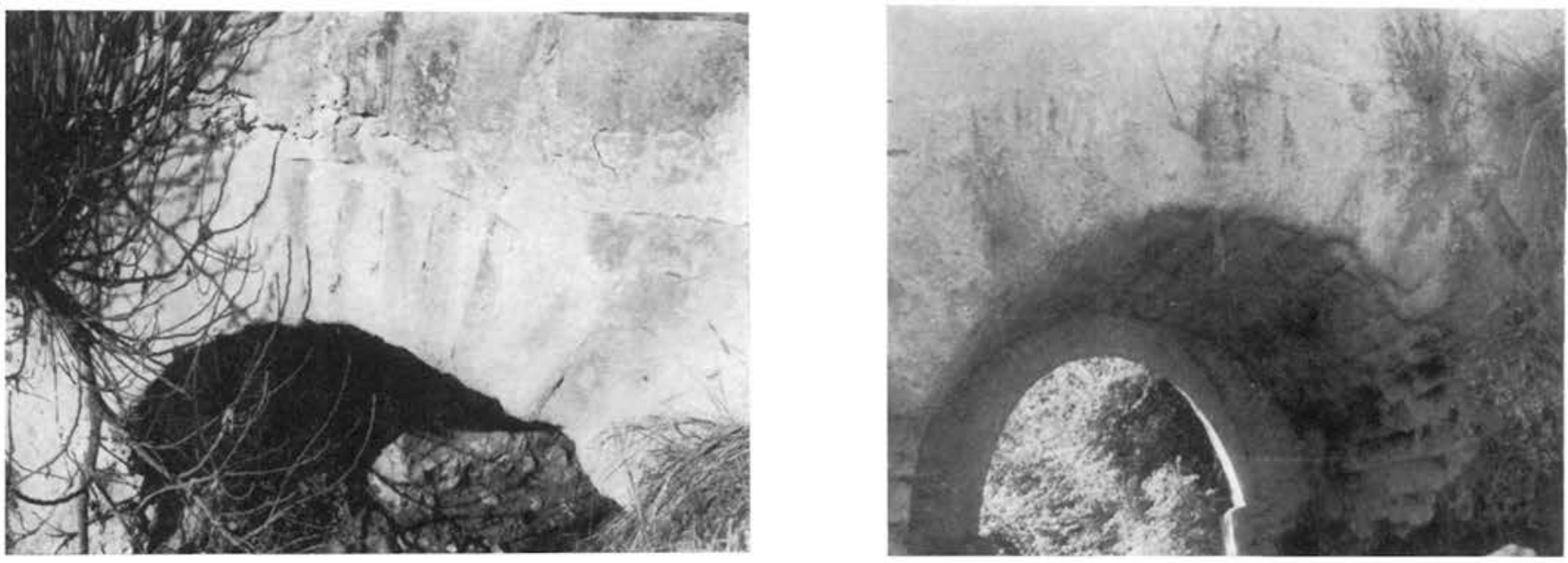

Alcantarilla romana en el arroyo de la Buena Agua.

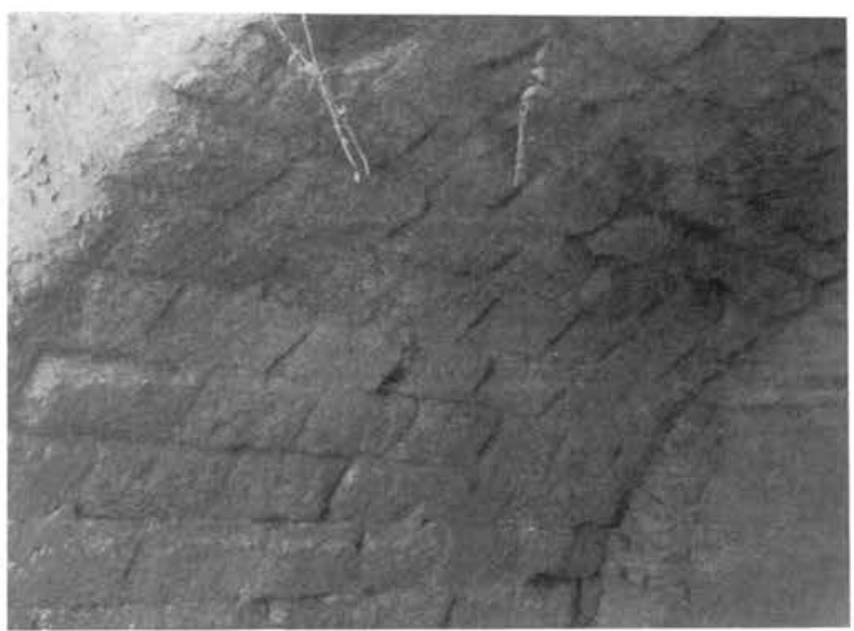

1 y 2. Frente de aguas arriba.

3 y 4 . Detalles de la boquilla con dovelas engatilladas.

5. Intradós de la bóveda.

Tenemos así relacionadas entre sí las tres obras pequeñas de este trozo, e incluso la menor con el puente de Córdoba, y desde luego esta última es, como ya hemos dicho, de una perfección que parece no corresponder a su pequeña importancia. Para encontrar otro puente con un engatillado parecido hay que remontarse al puente de Pinos sobre el Cubillas, en la provincia de Granada, que es de época mu. sulmana. 


\section{otros puentes que se han transformado - desaparecido}

Se citan por diversos autores puentes que en la actualidad se han transformado totalmente o bien no se encuentran los restos o quizás está equivocada la referencia inicial y ha ido pasando así de sus autores a los que han continuado en serie sucesiva de copias.

Ya hemos indicado nuestro criterio de considerar el puente adscrito a su procedencia romana por mucha transformación de materiales que sufra, e incluso cambiando la forma de algunos arcos que, al hundirse, se reconstruyen con arreglo a las posibilidades del momento; pero en muchos casos se ha reconstruido el puente entero cambiando además de emplazamiento, con lo cual se pueden utilizar los sillares romanos en la nueva obra, generalmente relabrándolos, y entonces cambia totalmente la forma, lo cual es posible aun volviendo al medio punto. A veces quedan frogones de la fábrica interna; pero en otros casos han debido destruirse éstos para obtener piedras de relleno, o bien depejar el cauce quitando obstáculos, pues 10 general es desplazarse poca distancia, pero variando las luces, con lo cual los restos perturban el encauzamiento del agua hacia los nuevos vanos.

Esto parece que ocurrió en el puente de Alcolea, donde debió existir uno romano que enlazaba las dos vías que venían por ambas orillas y después seguían unificados en la derecha. El puente actual

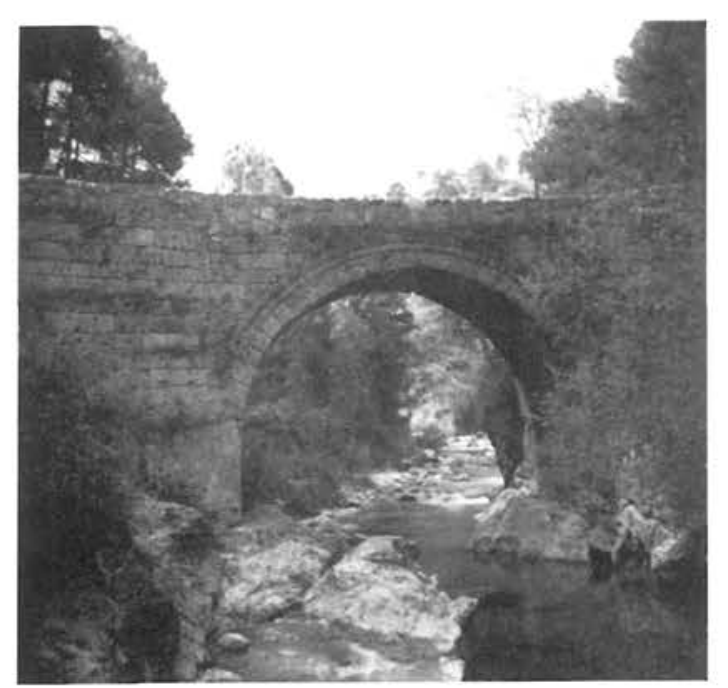

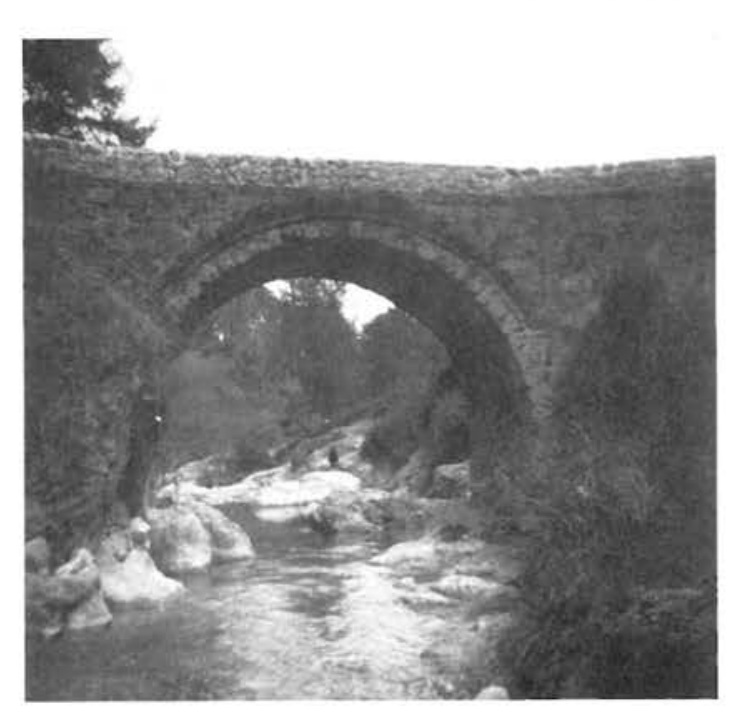

Puente de las Herrerias en Cazorla. Fotos L, F. Setién.

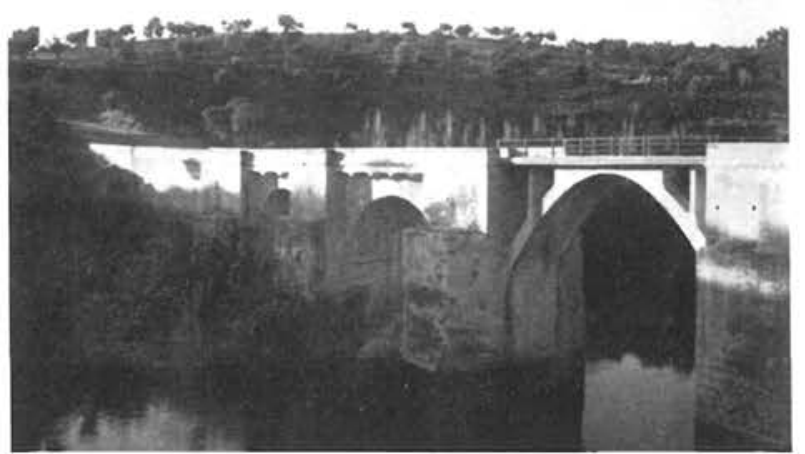

Puente de Bembézar. Arcos romano, musulmán y actual.

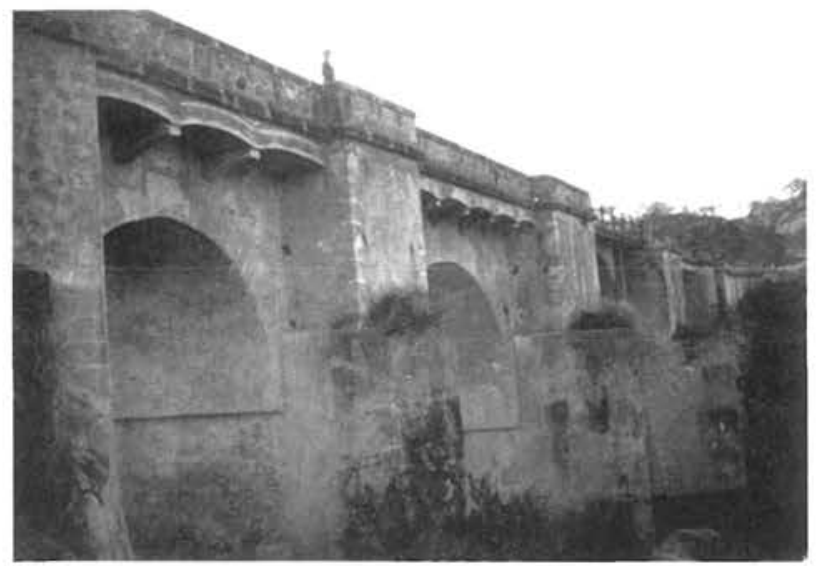

Puente de Bembézar. Arcos romano-musulmanes.

Puente das Herrerias en Cazorla, Fotos 

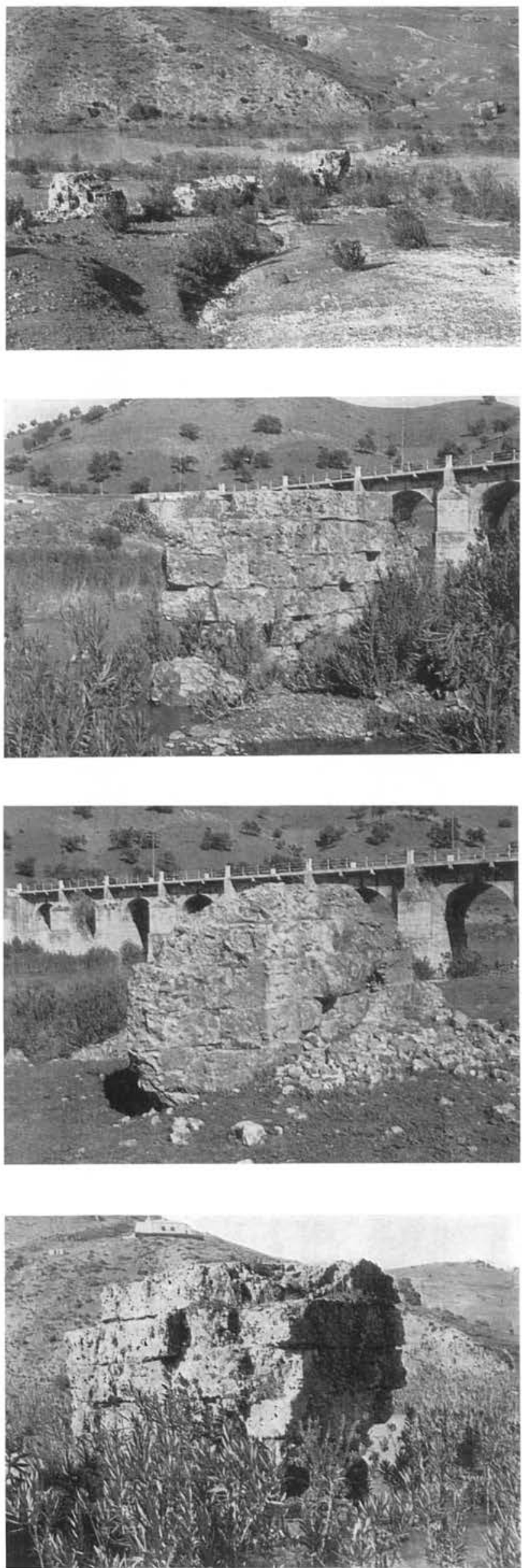

es de Carlos III. Parece que referencias, aunque con poco fundamento, indican que se cambió de emplazamiento hacia aguas abajo.

El caso clásico de estos puentes corresponde a Medellín, donde quedaron frogones que denuncian la situación de las pilas antiguas. Cosa análoga ocurre en el puente de Zamora, donde quedaron sólo los frogones y los sillares se trasladaron a mucha mayor distancia. En cambio, el puente de Guadix, que se cita como de época romana, no se encuentra sobre el Fardes o al menos resulta actualmente muy difícil de encontrar. Cea Bermúdez indica que sus sillares se utilizaron en construcciones de Guadix.

El puente de Zuazo, que ha sustituido al que daba nombre a la mansión terminal de la vía romana que finalizaba en Gades, se transformó totalmente en el siglo XV, siendo reconstruido por el señor de Zuazo, que le prestó su nombre. Posteriormente se convirtió en un puente metálico y creemos que del primitivo romano no se conserva nada. Dejamos la historia de estas transformaciones a su época oportuna. Sólo indicaremos que por dicho puente pasó la conducción de aguas a Gades en época romana.

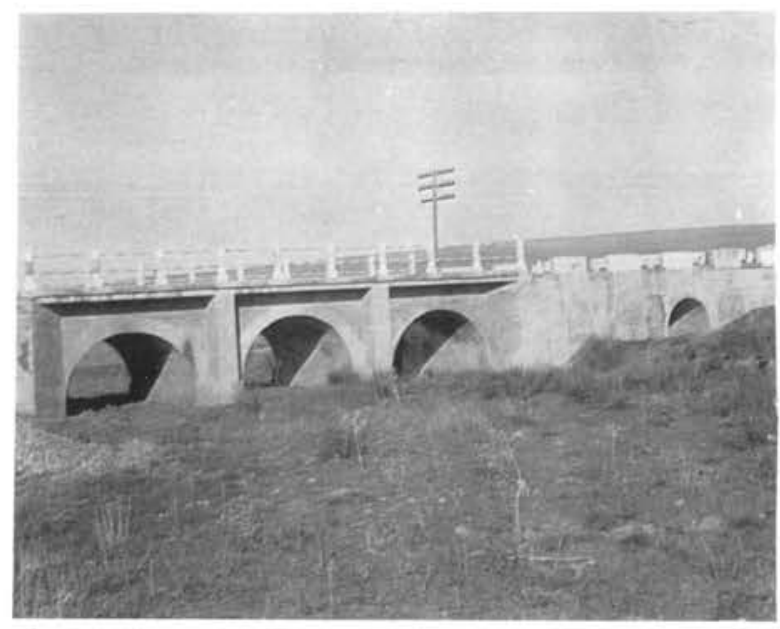

Puente del $\mathrm{km} 380$ de la carretera de Andalucía, antiguo romano $y$ actualmente completamente enmascarado.

Ruinas del puente de la Cala de Huelva en la vía roman de pura a laspalis de las que se arran. mente en servicio y que correspondia a Carlos III. 


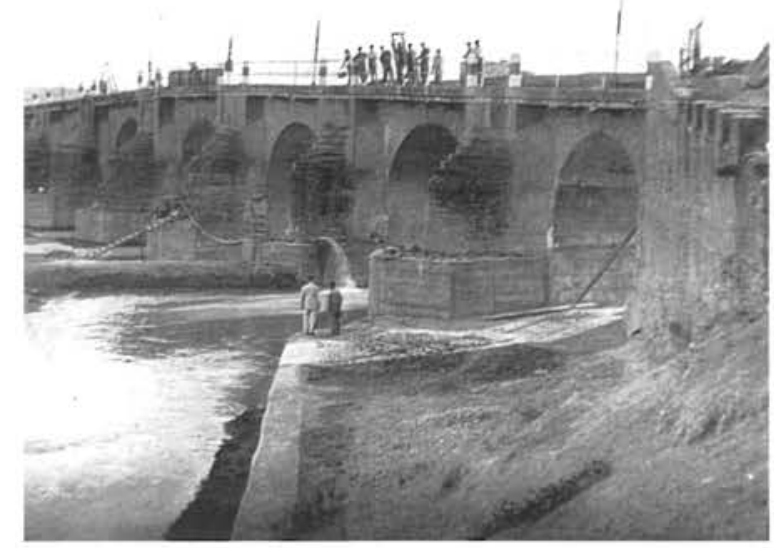

Puente de Guadajoz antes de realizarse la última reforma.

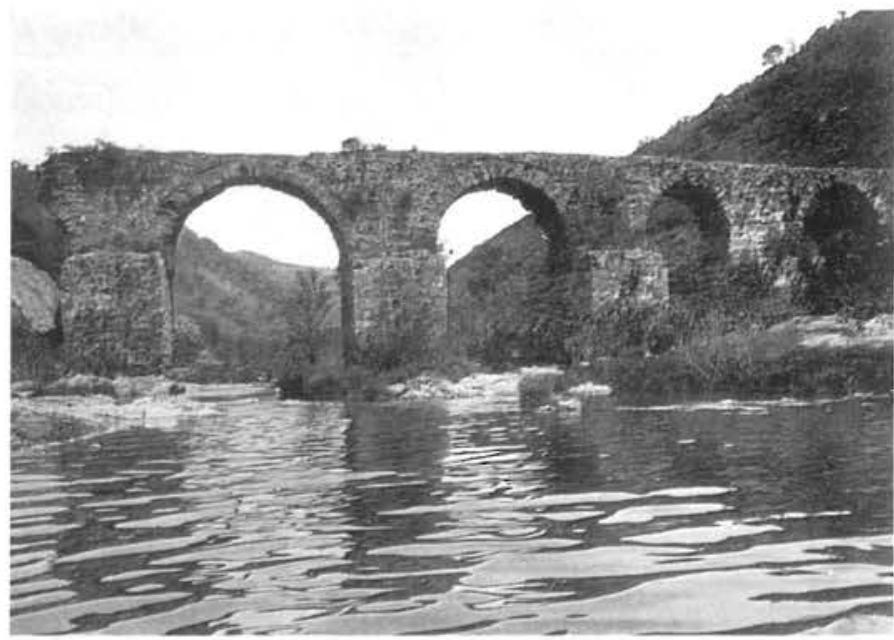

Puente del Guadiato: arcos romanos.
Puentes de pequeña im portancia que en la trans formación han quedado verdaderamente en otra forma existen unos cuantos en la actual carretera de Andalucía, que han sido desfigurados, unos en la re forma llevada a cabo por el Circuito Nacional de Fir. mes Especiales en los años treinta y otros cuando la correspondiente a Modernización de Carreteras, bien al plan REDIA. Así tenemos el de Guadajoz, a que ya nos hemos referido anteriormente, que se enmascaró tras una amplia-

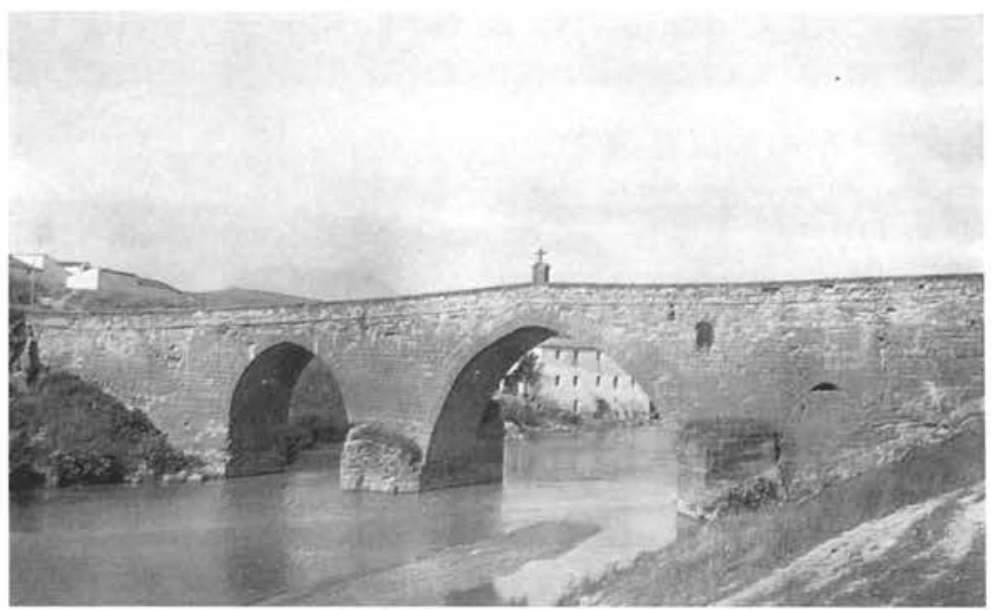

Puente de Ubeda la Vieja sobre el Guadalquivir, reconstruído en la E. M. sobre cimientos romanos.

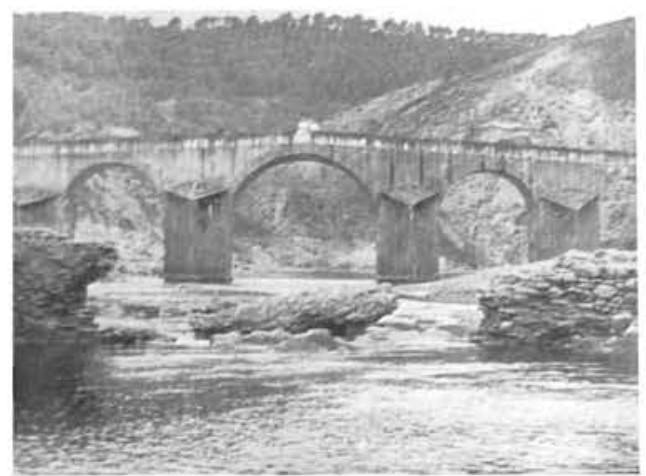

Puente de Granada: romano o musulmán.

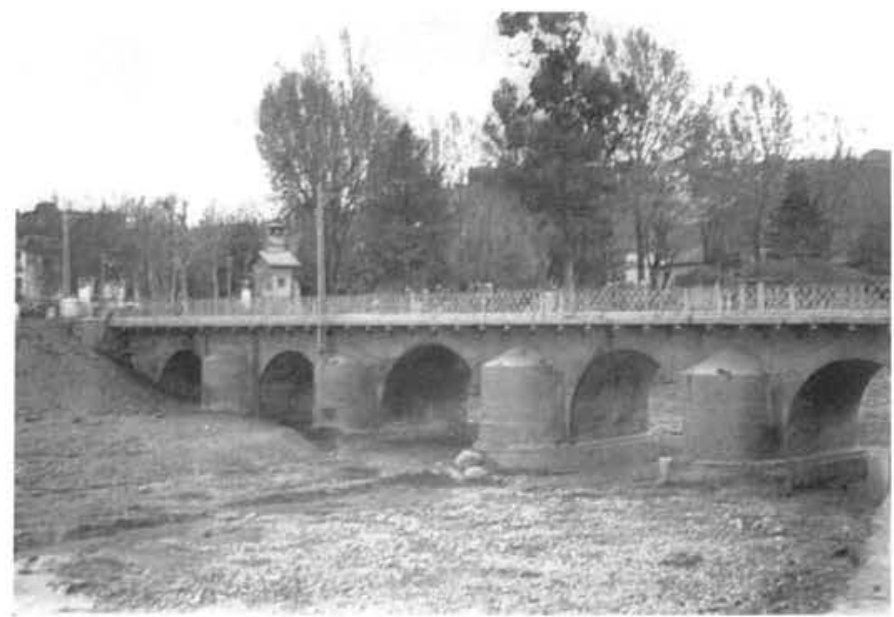




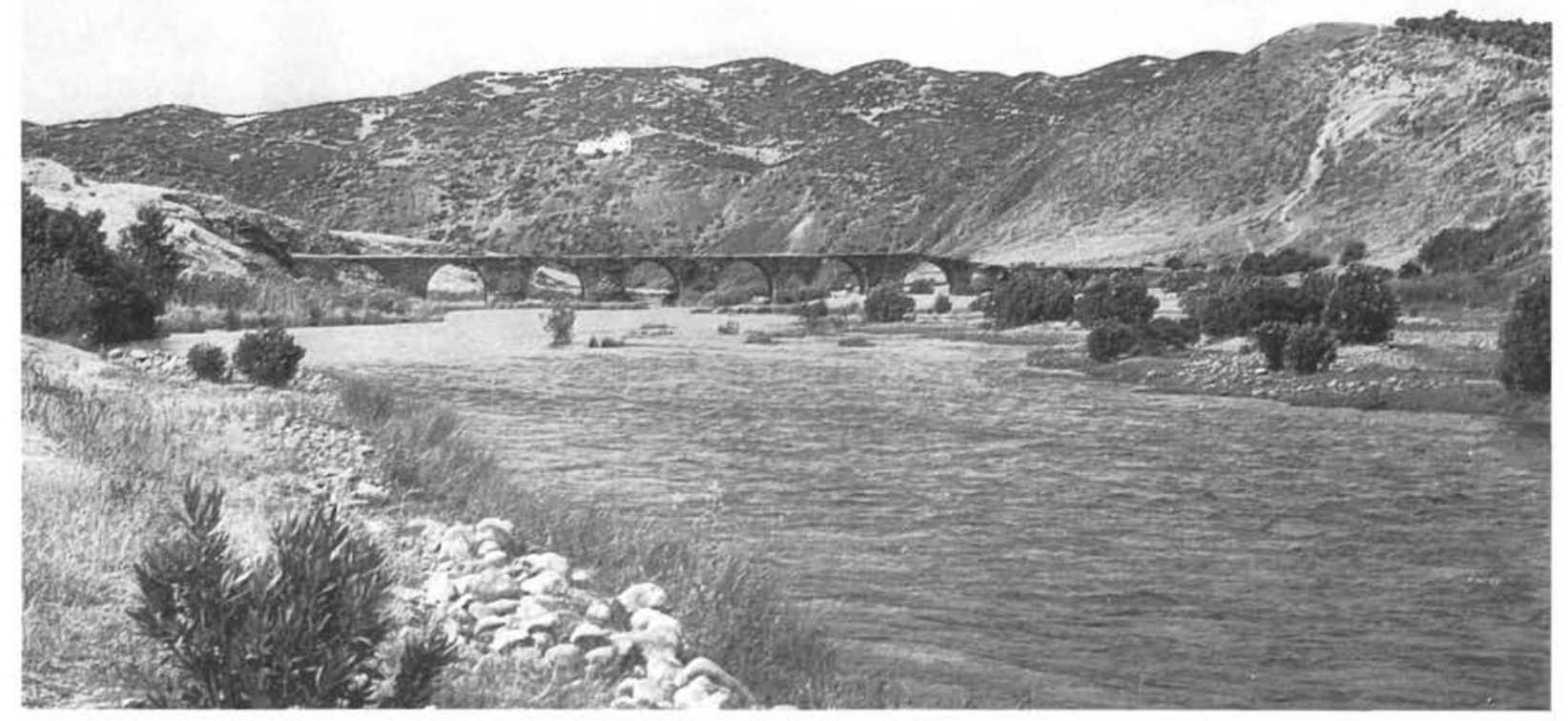

Tres vistas del puente del Jándula atribuido a los romanos pero, probablemente, del siglo XVI. (Fotos año 1954).

ción de pilas en fábrica de hormigón torpemente rematadas, después de haber tenido unos tajamares muy graciosos añadidos en el siglo XVIII.

En otros casos la importancia de la obra es menor, generalmente pontones de un solo vano. Así sucede con el pontón del arroyo Ahoganiños, cuyos frentes han desaparecido tras un plastrón de hormigón que ha permitido ensanchar la plataforma. Otro de ellos de tres pontones de 5,30 con pilas de 1,90 y vanos de $2,50 \mathrm{~m}$ en el kilómetro 380 , en el cual se han revestido además los paramentos interio. res.

Otro tanto le ocurre al puente del arroyo del Diablo, que está dentro del antiguo kilómetro 356 junto a un cortijo próximo a Villa del Río. Está desconocido pero lo citan Cea Bermúdez, Blázquez y Gómez Moreno. También le pasa algo parecido a un pontón en la carretera que se desvía hacia Montoro desde el kilómetro 358.
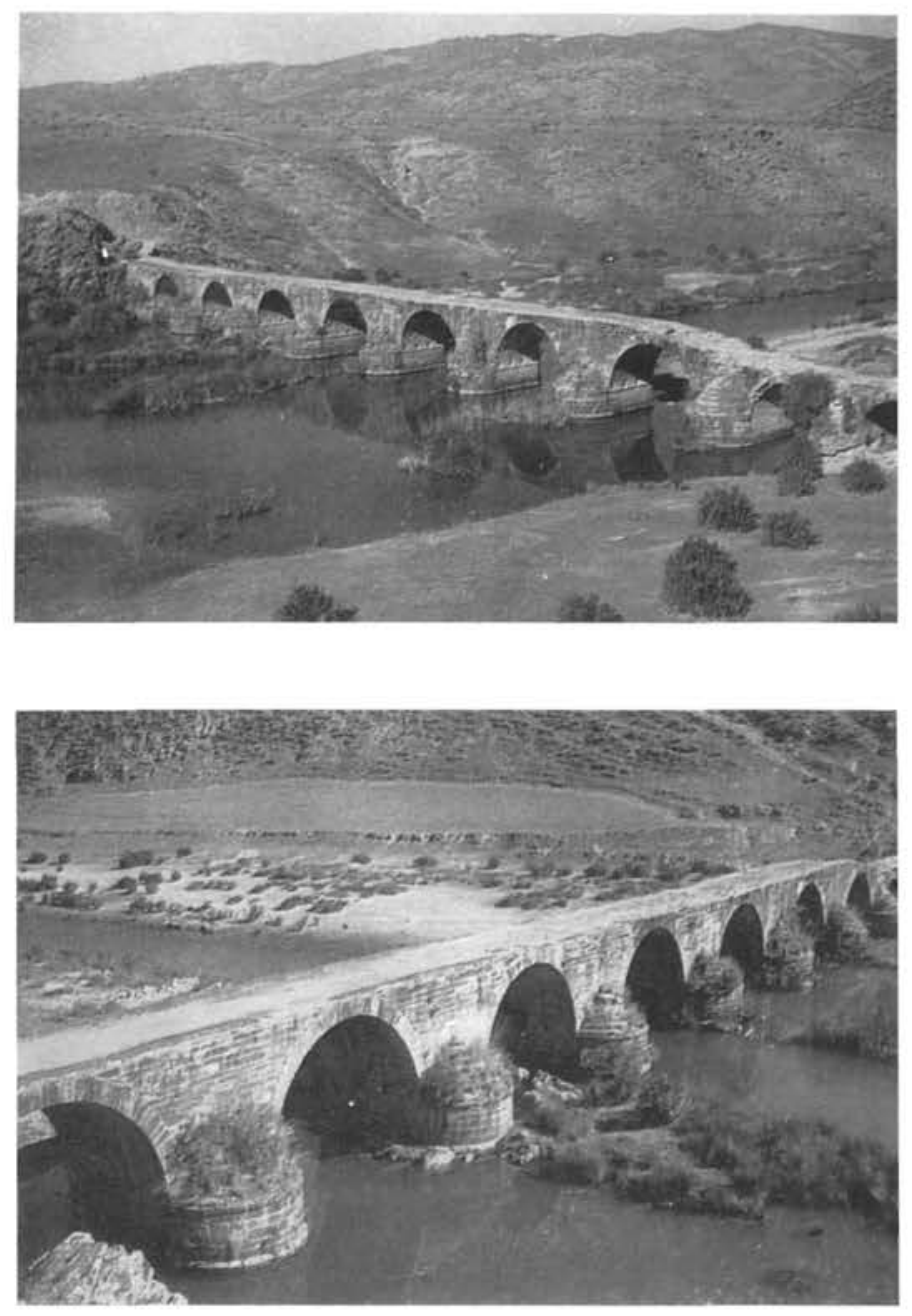
No se encuentra ningún vestigio de los puentes de San Pedro de Alcántara en la carretera de la costa o en la de enlace con Nerja, ni el de San Juan de Alfarache o Chavoya, citados por Cea Bermúdez y Celestino Espinosa.

En el caso del puente del Puerto de Santa María sobre el Guadalete, que Cea Bermúdez indicaba que tenía cimientos romanos, no se apreciaban en los estribos del puente metálico que reconocimos al verlo en los años veinte y que ha sido sustituido por uno de hormigón pretensado recientemente. El puente de Guadamalilla, en la carretera de Belalcázar en San Eufemia, que debía corresponder a la vía de Titulcia a Cástulo, tampoco es romano.

Tampoco hemos podido comprobar la referencia de Cea Bermúdez acerca del puente de Segura en el afluente del Guadalquivir cerca de su nacimiento.

En cambio, quedan pilas del puente de Lituergo sobre el Guadalquivir cerca de Santa Potenciana, en la zona denominada La Huesa, que según Blázquez corresponde a la mansión de Ititurgis, que luego se trasladó a Andújar.

También en la Puente Vieja de Ubeda, junto a la confluencia del Guadalquivir con el Jandulilla, se conservan pilas romanas análogas a las de Lituergo, sobre las que se voltearon tres arcos apuntados torpemente aparejados, utilizándose en tímpanos sillares romanos auténticos, así como en las boquillas relabrados, y también lápidas del próximo despoblado de Ubeda la Vieja.

ADVERTENCIA. Recordaremos que en el artículo relativo a puentes de época republicana hemos pasado revista a los siguientes que pertenecen a la Bética: Andújar, Villa del Río, Guadalmellato y Guadajoz.

El puente de Granada sobre el río Genil para la salida de la carretera hacia la costa, es otro puente de poca personalidad, con cinco vanos volteando su medios puntos sobre pilas rectangulares con planos enrasando tímpanos y boquillas, ha- 
biéndole adosado tajamares triangulares con retallos aguas arriba y cuerpos semicilíndricos aguas abajo. Estos adosamientos no deben ser romanos, sino arreglos posteriores casi con seguridad los de aguas arriba. También han debido modificarse los cimientos que aparecen como basamentos destacados de planta rectangular prolongada en semicírculos. Estas modificaciones pueden ser de cualquier época desde la Edad Media, y existen referencias vagas de construcción en el XII, aunque puede ser reconstrucción.

Dos modificaciones ha sufrido en el presente siglo, una al encauzarse el río entre muros, donde se debieron enterrar dos huecos de la margen izquierda, pues en cambio en la margen derecha van adaptándose al terreno en decrecimiento de luces, rompiéndose la simetría con la otra. También se ensanchó la plataforma disponiendo aceras voladas por ambos lados y sustituyendo el pretil por barandilla metálica. Para aumentar su falta de particularidad, los paramentos están totalmente enfoscados en la actualidad.

Torres Balbás indica que este puente es de época musulmana y en la guía de M. Gómez Moreno (padre) se recuerda que hay un grabado del siglo XVII de Francisco Heylan.

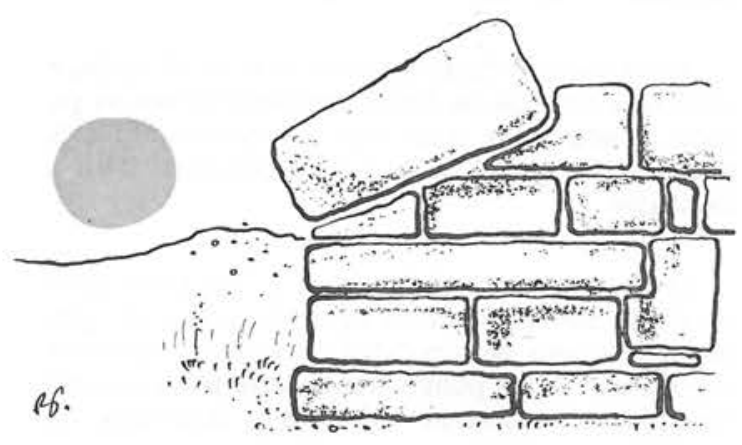




\section{referencias históricas y literarias}

\section{puente de Córdoba}

\section{(100) A. PONZ}

Viaje de España.-Tomo XVII.--Carta II.

La otra obra notable arriba, dije, es la del famoso puente sobre el Guadalquivir, preciso tránsito de los que van y vienen por el camino real. Esta obra es muy antigua, y aunque algunos escritores la atribuyen a los árabes, particularmente a Issen, hijo de Abderramán, que, como se ha dicho, concluyó la gran mezquita, hoy catedral, acaso parte de la obra es del tiempo romano. Tiene, si no me engaño, trece arcos, y se reconocen en ella algunas renovaciones.

En el ingreso, viniendo de Ecija, está fortificada la entrada del puente con un castillo muy bien conservado, y la puerta para en trar en la ciudad es de muy buena arquitectura, cuya decoración consiste en un gran arco con cuatro columnas pareadas de orden dórico a los lados, su cornisamento correspondiente y un ático por remate; todo ello obra grandiosa, que algunos creen ejecutada por planos de Juan de Herrera.

A poca distancia, un poco más abajo, se ven ruinas, al parecer de otro puente que iría a dar al antiguo alcázar, en el sitio donde ahora está el Tribunal de la Inquisición.

\section{(101) CELESTINO ESPINOSA.}

Reseña.-《R. O. P.».--Año 1878

A la entrada de la ciudad, sobre el río Guadalquivir, está situado este puente, de origen romano, construido en la vía que desde Tarragona atravesaba la Espartaría, y por Cástulo se dirigía a Córdoba.
Se menciona este puente por los historiadores al hacer referencia de la guerra que terminaron en esta región César y Pompeyo. Su situación es hacia la parte So. de la ciudad, en donde está la catedral, antigua mezquita, cerca del palacio episcopal y del sitio donde estuvo su alcázar, y contiguo donde estuvo un templo dedicado a Juno.

Según resulta de las crónicas de la ciudad, el califa Hixen I, que fue el que concluyó la mezquita, reparó este puente el año 787 . En 1369 se mandó reparar por Enrique II, y posteriormente se reparó también. Por esta causa se nota diversidad de forma y proporciones en los arcos, pues el primero es carpanel, y resulta como una adición a los antiguos, según un tramo de 6 arcos, los cuales debieron ser todos apuntados; pero en el 4 y 7 está modificada dicha forma; los 8 y 9 son de luces y formas desiguales con archivoltas, lo cual hace presumir fuesen los que hubo que reconstruir después de la crecida acaecida en 1684, cuando se estaba edificando, y que los destruyó. Los arcos 10 y 11 son casi idénticos y reformados en época moderna con tajamares, basamentos y pilastras o pedestales que se elevan hasta el pavimento, recibiendo el primero la estatua de San Rafael, patrón de Córdoba, y en la pila del tajamar, en un pedestal semicilindrico de mármol, se ve está la fecha de 1545 . Los arcos 12 y 13 son más antiguos y de origen árabe. El 14 antiguo deteriorado. El 15 es de construcción mo. derna, y el 16 está casi destruido, de estilo romano.

La piedra conchifera deleznable de que está construido este puente, hace se encuentre sumamente deteriorado, y en 1853 se hizo un reconocimiento, viendo ser muy malo el estado de los arcos 2 y 7 inclusive, estando realzadas las pilas de modo que estrechan la corriente, se reconoció estar fundado el puente sobre terreno de acarreo que cubre la capa de arcilla que forma el lecho del río, encontrando había sido construido, encachado y estacadas de defensa de éste.

Los 16 arcos, cuyas luces son variables, están sostenidos por pilas, las cuales tienen atinaderos para desagüe; sus espesores son de $5,294 \mathrm{~m}$ a $9.744 \mathrm{~m}$. La longitud del puente entre estribos es de $284,15 \mathrm{~m}$; la altura hasta el pavimento, $70,728 \mathrm{~m}$; la anchura entre los frentes, 7,60 a $8,00 \mathrm{~m}$. 
(102) LUIS SAINZ GUTIERREZ.

Datos históricos acerca de la construcción del puente llamado de Córdoba en la carretera de primer orden de Madrid a Cádiz. - " Ana les».-Tomo III.--《Revista de Obras Públicas».-Año de 1894.

Artículo de 180 páginas, dividido en dos partes y siete apénáices. La primera parte consta de XI capítulos donde se exponen todas las vicisitudes sufridas por el puente desde los romanos hasta el siglo XIX; y la segunda, dos capítulos en los que se completa la historia con lo ocurrido en este último siglo. Se acompaña un plano del puente tomado por el autor, que fue ingeniero encargado del puente, plano que reproducimos en el dibujo [31].

\section{puente de la Alcantarilla}

(103) GELESTINO ESPINOSA.

Reseña.--R. O. P.».-Año 1878.-Pág. 252.

En esta misma provincia hay un puente, al que se da el nombre de Alcantarilla en el libro "Guía del viajero por el ferrocarril de Sevilla a Cádiz», del señor Rodríguez, por estar cerca de la estación de este nombre y es también de época romana con dos torres.

(104) GOMEZ MORENO.

Se han utilizado las fotografías que aparecen en este artículo y que se indican de época anterior, que debe comprender a los ấios veinte.

(105) Catalogo de monumentos españoles arQuiTECTONICOS E HISTORICO-ARTISTICOS.

Centro de Estudios Históricos.-Madrid, 1932.-Tomo II.-Página 273.-Una foto.

Número 826. Puente de La Alcantarilla.-En un despoblado y hos estación del ferrocarril entre Sevilla y Cádiz, en término de Utrera. Le da nombre un puente romano sobre el río Salado de Morón, que conservó hasta principios de este siglo dos torres defensivas medievales a los extremos, segín fue dibujado en el siglo XVI. Quedan sus dos arcos de medio punto hechos de sillería a la rústice, como igualmente los tímpanos; entre aquéllos vese destrozado otro pequeño arco sobre el que se extendía una inscripción monumental inédita y ya conocida en extremo, pero aún legible su primera línea, que dice: "Augustus potem». Estâ abandonado y fuera de camino ya.

\section{Carmona}

(106) HERNANDEZ DIAZ, SANCHO CORBACHO \& COLLAN. TES DE TERAN.

Catálogo Arqueológico de la provincia de Sevilla.-Tomo II.pág. 114.

Se conserva, aunque muy desfigurado por las reconstrucciones, pues estuvo en uso hasta nuestros días, el puente que, a media ladera, daba paso a esta calzada sobre un arroyo; tiene cinco arcos, el central de $5 \mathrm{~m}$ y de 4 los demás, con pilares y tajamares de piedra, arcos de ladrillo y el resto de la obra de mampostería; la pavimentación de la calzada, cuya anchura es de $6,50 \mathrm{~m}$, está formada por un enlosado de grandes piedras irregulares, visible en algunas partes del trayecto entre la Puerta de Córdoba y el puente, y muy principalmente sobre éste, teniendo también guardacantos de trecho en trecho.

\section{Alcalá de Guadaira}

(10y) MADOZ.

Diccionario Geográfico.-Tomo I.-Pág. 361.

En el Guadaira hay un puente de sillería de siete grandes ojos, de arquitectura romana, reedificado a expensas de los fondos pú. blicos en el año 1870, cuya obra costó 50.700 reales; es bastante capaz y sólido y el único pasaje para los puertos en el invierno.

(108) HERNANDEZ DIAZ, SANCHO GORBACHO \& COLLAN TES DE TERAN.

Catálogo Arqueológico y Artístico de la provincia de Sevilla.Tomo I.-Pág. 48.-Fotografías pág. 85.--Sevilla, 1939.

Citaremos por último, como construcción de origen romano el hermoso puente de piedra sobre el Guadaira, formado por siete arcos sobre estribos con tajamares. Su primitiva fábrica ha sufrido múltiples restauraciones, ya que fue durante siglos el único paso para los puertos en época de inundación. Queda constancia docu mental de obras llevadas a cabo en él a fines del siglo XVI y de la gran reedificación efectuada en 1780 a expensas de los fondos públicos y que costó 50.700 reales.

Se encuentran además noticias sobre obras efectuadas en él en las actas capitulares de 19 de septiembre de 1541,25 de julio de 1617,10 de enero de 1672 y 14 de septiembre de 1717. Obras en la puente horadada se acuerda efectuar en el cabildo de 24 de enero de 1633. 
(109) FLOREZ.

Anales de Alcalá de Guadaira.-Tomo I.

Catálogo de Monumentos Españoles Arquitectónicos y Artísticos.-

Centro de Estudios Históricos.-Madrid, 1932.

INSCRIPCION: En la fachada de la casa de la huerta de la rapada, sita en uno de los extremos del puente, hay una lápida que dice así:

REYNANDO EL SENOR DON CARLOS III, SE REEDIFICO ESTE PUENTE $Y$ CUESTA DEL MATADERO, EXPENSA DE LOS CAUDALES PUBLICOS, Y COSTO 50.700 REALES. AÑO 1780 .

\section{puente de Ronda}

\section{(110) MADOZ.}

Diccionario Geográfico.-Tomo XIII.-Pág. 559.

Ia empinada calle del Puente Viejo, que se une luego al segundo un poco más arriba del punto en que se encuentra la cortadura unida por el puente de un solo arco, que fue construido por los romanos y reedificado en tiempo de los árabes, dicho arco descansa por ambos lados sobre los mismos tajos, teniendo sólo 43 varas de material y 40 de profundidad hasta la superficie del río. Debajo de este puente y al pie del peñasco que lo sostiene, existe una cueva formada por la naturaleza en la misma piedra, dentro de la cual nace el cristalino y copioso nacimiento de la Mina. Fuera de la población se encuentra en este mismo lado otro puente pequeño de un solo arco con 13 varas de altura, edificado por los árabes, el cual daba paso a los habitantes del barrio de San Miguel, del que no se conservan más vestigios que algunos montones de piedra, y la ermita de su nombre.

\section{Aznalcázar}

(111) HERNANDEZ DIAZ, SANCHO CORBAGHO \& GOLLAN TES DE TERAN.

Catálogo Arqueológico y Artístico de la provincia de Sevilla.Tomo I.-Pág. 183

E1 puente sólo conserva hoy, por la orilla correspondiente a pueblo, cinco de los catorce arcos que tenía según Madoz, y algunos restos informes de la margen opuesta, su anchura es de 5,20 m; la obra es de ladrillo y los arcos semicirculares, de doble rosca, teniendo las pilas tajamares de forma semicónica. Las numerosa restauraciones que hubo de sufrir para mantenerlo en buen uso no han logrado desfigurar por completo su traza romana; de alguna han logrado desfigurar por completo su traza romana; de alguna de Aznalcázar; por uno de estos documentos parece que el puente tuvo una parte de piedra, quizás la central, más expuesta a los embates de la corriente.

Nota 4. En el archivo municipal de Aznalcázar hemos hallado las siguientes partidas:

En cabildo de viernes 20 de febrero de 1551 se urge a la ciudad de Sevilla para que lleve a cabo los reparos de la puente. (Libro capitular de 1551-1563 S. T.).

En el de 7 de diciembre de 1606 se acordó que la obra de la puente no se haga ni comience hasta 1.0 de abril de 1607 uatento que los días serán mayores y los materiales más baratos y el rio no saldrá de manera que haga dañon. (Libro capitular de 1600-1610. Fol. 163 vto.).

Por acuerdo capitular de 25 de junio de 1724 se informa al Cabildo y Regimiento de la ciudad de Sevilla de la ruina en que se halla el puente de piedra sobre el Guadiamar y la imposibilidad en que se halla el Concejo de Aznalcázar de atender a su reparación.

(112) MADOZ.

Diccionario Geográfico.-Tomo III.-Pág. 212.

Sobre el río Guadiamar existe un puente de construcción romana de 20 varas de alto sobre la superficie del agua, con 14 ojos.

\section{(113) ANTONIO TERRONES Y ROBLES.}

Vida, martirio, traslación y milagros de $s$. Eufrasio, mártir, obispo y patrón de Andújar.-Págs. 284-301.

Acordamos del milagro de la puente de Guadix que estando firme para que él pasase se cayó pasando los enemigos que le perseguían dejándolos todos en el río ahogados. Santo abogado de las puentes y de los ríos, para que no os ahoguéis no hubiera de ir hombre a nadar al río, ni habrá de pasar por esa puente sin ser devoto de S. Eufrasio.

\section{puente sobre el río Jándula}

(114) CELESTINO ESPINOSA.

«Revista de Obras Públicas».-Año 1878.-Pág. 251.

Está situado fuera de la carretera y se cree sea de la misma época en que se construyó el de Andújar; debió servir para comunicarse con las Castillas, la colonia romana, Porcira o más bien Obulco, hoy Porcuna, o con los Pedroches de Córdoba, en donde se explotó mucho mineral. Es de sillería y se encuentra en estado ruinoso y sin pretiles. Tiene 10 claros, tres de ellos de $4,70 \mathrm{~m}$, y $8,90 \mathrm{~m}$ los demás; su altura máxima es desde el lecho del río a las bóvedas $7,59 \mathrm{~m}$, la longitud total $127 \mathrm{~m}$ y el ancho entre pretiles $5,14 \mathrm{~m}$. 


\section{puente del Puerto de Santa María}

\section{(115) CEA BERMUDEZ.}

Sumario de antigüedades romanas.-Pág. 279.

No han quedado de sus antiquísimos y respetables edificios más que algunos oscuros vestigios en el recinto de la ciudad y dentro del mar, y los cimientos del puente sobre el río.

\section{(116) PONZ.}

Viaje de España.-Carta II.-Tomo XVIII.

Se han hecho recientemente dos puentes de barcas para los dos brazos del Guadalete... Se pasa el segundo puente antes de entrar en la ciudad. Se compone de siete barcas entramadas. Se llaman de San Alejandro y en ambos hay sus compuertas para dar paso a los barcos de tráfico que van y vienen de la bahía de Cádiz y otros puertos.

\section{(117) MADOZ.}

Diccionario Geográfico.-Tomo XIII.-Pág. 280.

Sobre este rio hace dos años se construyó un elegante puente colgante llamado de San Fernando, por donde pasa la cerretera general. En la vía de San Pedro hay otro puente como el anterior.

\section{puente de Alcolea}

\section{(118) CEA BERMUDEZ.}

Sumario de antigüedades romanas.-Pág. 349.-Madrid 1832.

Aunque se ha reedificado en varias épocas, fue romano en su principio, como lo manifiestan sus robustos cimientos.

\section{(119) MADOZ.}

Diccionario Geográfico.-Tomo I.-Pág. 457.

Se pasa el Guadalquivir por un magnifico puente de jaspe negro reedificado por el señor D. Carlos III.

\section{(120) PONZ.}

Viaje de España.-Tomo XVI.-Carta VII.

Se está construyendo sobre el Guadalquivir un magnifico puente nuevo y sería una de las obras más importantes y suntuosas del nuevo camino desde esa corte a Cádiz...

Yo he pasado en otras ocasiones este río por el puente antiguo, que me pareció en gran parte fábrica romana; pero estaba ya deteriorado y era demasiado angosto. Si no me engaño le conté veinte arcos; éste ya tiene hechos una docena, y llegarán, seguin creo, al mismo número.

\section{I B U J O S}

[31] Dibujos del Ingeniero de Caminos, Canales y Puertos don Luis Sáinz Gutiérrez. "Anales de la Revista de Obras Públicas», tomo III, año de 1894, con el título de: Datos históricos acerca de la construcción del puente llamado de Córdoba en la carretera de primer orden de Madrid a Cádiz.

[32] Cordube. Grabado del siglo XVI con un elogio en francés de la riqueza y grandeza de la ciudad.

[33] Puente de Córdoba, del Viaje de España, de don Antonio Ponz. Tomo XVII, Carta II, 1791.

[34] Córdoba. Grabado de la Colección David Roberts. Drawn by David Roberts. Engraved by J. Lausen. Publicado Robert Jenning. Londres, 1835.

[35] A. DE LABORDE: Vista general de Córdoba. Las referen cias al pie son: Liger del. Devilliers Jeune sculp. 1312

Vista desde aguas abajo y ladera izquierda.

[36] J. C. MURPHY: The Bridge of Cordova. Publicado en Lon dres por Cadell \& Davies, junio 1815.

Las referencias al pie son: J. C. Murphy del y Engraved by J. Le Keux. Punto de vista análogo al de $A$. de Laborde, aunque más próximo al castillo de La Calahorra.

[37] M. BERDIGUIER: Vista del magnífico y suntuoso Triunfo del Arén S. Rafael. Editado en Madrid en 1781. Grabador Bautista Varquez. Monumento erigido al Arcángel S. Rafael entre la Casa de Aduana y los Graneros de la Iglesia Catedral, cerca de la puerta principal del puente.

[38] CHAPUY: Puente de Córdoba. Litografiado por F. Cicéri e imprimido por Lemercier y editado en Bulla, Paris. Vista desde punto análogo al de Laborde y Murphy.

[39] G. VIVIAN: Bridge of Cordova. Vista del puente desde aguas arriba. Referencias G. Vivian del. L. Haghe Lith. 1833.

[40] LEMAITRE: Cárcel de la Inquisición en Córdoba. Vista de los edificios correspondientes a la Cárcel de la Inquisición situados en la orilla derecha del Guadalquivir, junto a la puerta del Puente con el acueducto para llevar el agua a la rueda hidráulica árabe.

[41 y 42] Puente, Mezquita y Catedral desde aguas arriba orilla izquierda. Dos interpretaciones anónimas del siglo XIX.

[43] Lemaitre: Górdoba. Vista de puente y catedral desde el punto de vista tradicional frente a los molinos. Siglo XIX. Sancheret del. Lemaitre direxit.

[44] J. VALLEJO: Puente, mezquita y catedral. Lit. de J. Donon. Madrid, siglo XIX, desde el punto de vista clásico tomada del na tural con detalles de tajamares $\mathrm{y}$ arcos.

[45] Castillo de La Calahorra y Puente, de la obra "España: sus monumentos y artes", Córdoba, por Pedro de Madrazo, 1886. Gra bado de fotografía mostrando las fábricas del puente a final del siglo XIX.

[46] Vista general de Córdoba. Dibujada por F. González y grabada por Castro con gran detalle de pilas y tajamares, probablemente tomada de fotografia.

[47] PIERREVANDER: Alcantarilla. Grabado de la serie La Galerie Agréable du Monde. Leyden, 1720.

El puente en el camino de Sevilla con dos torres defensivas (ca bezas), una número 83 venta y una construcción musulmana llamada vieja mezquita.

[48] GeORges HófNAGEL. Ecija, del Civitates Orbis Terra rum. Sevilla, 1567. Indica la estructura del puente con tajamares puntiagudos y torres defensivas antes de la reforma de Carlos III.

[49] Ecija. de La Galérie Agréable du Monde. 1720, núm. 69. Grabado inspirado en el anterior.

[50] CHAPUY: Entrada al puente de Ecija, litografiado por Bichebois, imprimido por Lemercier y editado en París por Bulla, número 50, siglo XIX, apareciendo claramente la reforma de Carlos III. 